UNIVERSIDADE DE SÃO PAULO

INSTITUTO DE PSICOLOGIA

ROSELI ALMEIDA DA COSTA AMENI

Padronização Brasileira do Teste

Hooper de Organização Visual

(Versão Corrigida)

SÃO PAULO

2015 
ROSELI ALMEIDA DA COSTA AMENI

\section{Padronização Brasileira do Teste \\ Hooper de Organização Visual}

(Versão Corrigida)

Tese apresentada ao Instituto de Psicologia da Universidade de São Paulo como requisito parcial à obtenção do grau de Doutora em Psicologia

Área de concentração: Psicologia Escolar e do Desenvolvimento Humano.

Orientadora: Profa. Dra. Irai Cristina Boccato Alves

São Paulo 
NÃO AUTORIZO A REPRODUÇÃO E DIVULGAÇÃO TOTAL OU PARCIAL DESTE TRABALHO.

Catalogação na publicação

Serviço de Biblioteca e Documentação

Instituto de Psicologia da Universidade de São Paulo

\section{Ameni, Roseli Almeida da Costa.}

Padronização Brasileira do Teste Hooper de Organização Visual/Roseli Almeida da Costa Ameni; orientadora Irai Cristina Boccato Alves - São Paulo, 2015.

$169 \mathrm{f}$.

Tese (Doutorado) - Instituto de Psicologia da Universidade de São Paulo. Programa de Pós-Graduação em Psicologia. Área de Concentração: Psicologia Escolar e do Desenvolvimento Humano.

1.Teste Hooper, 2. Percepção Visual, 3. Avaliação Neuropsicológica, 4. Distúrbios da visão. I Título. 
Nome: Ameni, Roseli Almeida da Costa

Título: Padronização Brasileira do Teste Hooper de Organização Visual

Tese apresentada ao Instituto de Psicologia da Universidade de São Paulo para obtenção do título de Doutora em Psicologia

Aprovada em:

Banca Examinadora

Prof.Dr.

Instituição:

Assinatura:

Prof. Dr.

Instituição:

Assinatura:

Prof. Dr.

Instituição:

Assinatura:

Prof. Dr.

Instituição:

Assinatura:

Prof. Dr.

Instituição: Assinatura: 
Ao meu muito amado filho Beto por compreender a minha ausência em alguns momentos de nossas vidas devido aos meus estudos constantes. Pelo nosso amor incondicional e carinho intenso.

Ao meu esposo Roberto, minha gratidão eterna por sua grandiosa ajuda durante toda a minha carreira acadêmica. Com certeza você foi um anjo que caminhou ao meu lado me ajudando a eliminar todos os obstáculos do caminho, tornando os meus passos mais leves.

À minha mãe D. Lourdes, musa inspiradora que, apesar da sua humildade e simplicidade, sempre foi uma guerreira muito valente e ensinou a todos os seus filhos que a dignidade é um direito, mas, deve ser conquistada.

Ao meu pai amado Nelson, in memorian, que, infelizmente, não está presente fisicamente para comemorar a minha grande conquista, mas, com certeza, se faz presente de outra forma.

Aos meus irmãos de DNA, de amor e de espírito: Lene, Roni e Edinho, por fazerem parte da minha vida e por dividir a nossa história de lutas e vitórias.

Ao Oliver e a Eva, nossos queridos mascotes por me acalmarem nos momentos mais estressantes, mostrando alegria e companheirismo em todas as horas. 


\section{AGRADECIMENTOS}

À minha querida Mestra Profa. Dra. Irai Cristina Boccato Alves, a quem tenho profundo respeito, carinho e admiração. Por toda a paciência e orientação segura com que me guiou durante todo o processo da minha pesquisa, contribuindo para o meu progresso científico e intelectual.

Aos examinadores que participaram da minha qualificação e que muito colaboraram para o desenvolvimento do meu trabalho, Profo ${ }^{\circ}$ r. Elizeu Coutinho e Profo Dr. José Fernando Bitencourt Lomônaco, pelas valiosas sugestões.

À Profa Dra Maria Isabel da Silva Leme pela gentileza na correção do abstract.

Ao Centro Editor de Testes e Pesquisa em Psicologia (CETEPP) representado pelos simpáticos e solícitos Udo e Marianne. Por todo o auxílio prestado e apoio financeiro.

À minha amiga de longas datas, a psicóloga Karina Maki, pela contribuição na coleta de dados.

À minha querida nora Vanessa e à sua família pela grande ajuda nos contatos com os representantes das comunidades de igrejas e associações de bairro.

Aos proprietários das empresas participantes e diretores dos centros de recreação pela gentileza em ceder o espaço para as coletas de dados.

Aos meus alunos da Pós em Neuropsicologia e à psicóloga Elizabeth Lopes Musmicker pela imensa colaboração na coleta dos dados.

A todas as pessoas que gentilmente aceitaram participar deste estudo. 
E, acima de tudo, ao grandioso Deus, que tornou possível este momento. Sempre caminhando comigo e, durante os meus tropeços, segurou em minhas mãos e firmou os meus pés no chão para que eu não caísse, me fazendo crer que seria capaz de chegar ao fim do caminho. 
Numa folha qualquer eu desenho um sol amarelo. E com cinco ou seis retas é fácil fazer um castelo. Corro o lápis em torno da mão e me dou uma luva. E se faço chover com dois riscos tenho um guarda-chuva. Se um pinguinho de tinta cai num pedacinho azul do papel, num instante imagino uma linda gaivota a voar no céu. Vai voando, contornando a imensa curva norte-sul. Vou com ela viajando Havaí, Pequim ou Istambul. Pinto um barco a vela branco navegando. É tanto céu e mar num beijo azul. Entre as nuvens vem surgindo um lindo avião rosa e grená. Tudo em volta colorindo com suas luzes a piscar. Basta imaginar e ele está partindo, sereno e lindo. E se a gente quiser ele vai pousar.

Numa folha qualquer eu desenho um navio de partida com alguns bons amigos bebendo de bem com a vida. De uma América a outra consigo passar num segundo. Giro um simples compasso e num círculo eu faço o mundo. Um menino caminha e caminhando chega no muro. E ali, logo em frente, a esperar pela gente o futuro está. E o futuro é uma astronave que tentamos pilotar. Não tem tempo nem piedade nem tem hora de chegar. Sem pedir licença muda nossa vida, depois convida a rir ou chorar. Nessa estrada não nos cabe conhecer ou ver o que virá. O fim dela ninguém sabe bem ao certo onde vai dar. Vamos todos numa linda passarela de uma aquarela que um dia,enfim, descolorirá.

Numa folha qualquer eu desenho um sol amarelo, que descolorirá. E com cinco ou seis retas é fácil fazer um castelo, que descolorirá. Giro um simples compasso e num círculo eu faço o mundo, que descolorirá.

Toquinho 


\section{RESUMO}

Ameni, R. A. C. (2015). Padronização Brasileira do Teste Hooper de Organização Visual. Tese de Doutorado, Instituto de Psicologia, Universidade de São Paulo, São Paulo .pp. 169.

O Teste Hooper de Organização Visual (Visual Organization Test - VOT) foi publicado em 1958 e revisado em 1983. É um instrumento para avaliar a capacidade de organização visual dos estímulos, sendo sensível aos danos neurológicos. O teste é composto por 30 figuras de objetos comuns fragmentadas em duas a quatro partes, mostradas na forma de quebra-cabeças em cartões com fundo branco. Os itens são apresentados um a um para que o examinando diga o nome da figura que seria formada e se as partes do desenho fossem juntadas corretamente. O objetivo desta pesquisa foi realizar estudos psicométricos de padronização, validade e precisão do Teste Hooper para a cidade de São Paulo. Para isso, inicialmente foi investigada a existência de diferenças em relação às variáveis idade, sexo e escolaridade. A precisão foi avaliada por meio do reteste e pelo método das metades e a validade foi obtida pela correlação com os testes Figuras Complexas de Rey (Figura A), e os subtestes Cubos e Armar Objetos da Escala WAIS-III. Também foi feita a análise de itens para determinar a sua dificuldade. A amostra foi composta por 969 adultos de ambos os sexos, sendo 53,5\% mulheres e 46,5\% homens, com idades entre 18 e 82 anos, que foram subdivididos em seis subgrupos, e a escolaridade variou de ensino fundamental a superior. Os resultados da Análise de Variância indicaram a existência de diferenças significantes $(p \leq 0,05)$ entre os sexos, as faixas etárias e os níveis de escolaridade, bem como em todas as interações entre essas três variáveis. Os testes Post Hoc de Tukey indicaram diferenças entre as médias dos três níveis de escolaridade, em agrupamento das faixas etárias em quatro conjuntos. Os testes $t$ apontaram diferença entre os sexos apenas na faixa de 61 anos ou mais e para o nível de escolaridade superior, com pontuação maior para os homens. Foram estabelecidas normas em percentis em função da escolaridade e faixa etária para a amostra total e separadas para cada sexo, para o ensino superior e para as idades de 61 anos ou mais. A precisão pelo reteste evidenciou alta correlação $(0,897)$ entre os 
resultados das duas aplicações. A precisão das metades entre itens pares e ímpares, corrigida pela fórmula de Spearman-Brown foi de 0,884. Para a validade com outros testes que avaliam a organização perceptiva visual as correlações foram significantes (entre 0,302 e 0,543). A análise da dificuldade dos itens mostrou a necessidade de sua reordenação em função da sua dificuldade e também a necessidade de rever os critérios de avaliação de alguns elementos, pois em determinados casos será necessário rever as respostas que são consideradas como de 1 ou 0,5 pontos. Propõe-se também uma nova ordem para a apresentação dos itens na aplicação. Assim, as normas estabelecidas nesta pesquisa, bem como os dados de precisão e de validade, podem permitir a utilização do Teste Hooper para a nossa população, fornecendo critérios seguros para auxiliar no diagnóstico de pacientes com queixas relativas a problemas neurológicos.

Palavras-chave: Teste Hooper. Percepção visual. Avaliação neuropsicológica. Distúrbios da visão. 


\begin{abstract}
Ameni R. A. C. (2015). Brazilian Standardization of Hooper Test for Visual Organization. Tese de Doutorado, Instituto de Psicologia, Universidade de São Paulo, São Paulo. pp. 169.
\end{abstract}

The Hooper Visual Organization Test (VOT) was published in 1958 and reviewed in 1983. It is a device to evaluate the ability of visual stimuli organization, being sensitive to neural damages. The test is composed by 30 pictures of common objects separated into two to four pieces, presented in a puzzled way on white background cards. The items are presented one by one so that the examinee says the name of the picture that would be formed, if the parts of the drawing were gathered correctly. The aim of this research was to carry out psychometric studies of standardization, validity and reliability of Hooper Test for the city of São Paulo. Therefore it was initially investigated the existence of differences in relation to such variables as age, sex and school grading. The reliability was evaluated through a retest and the split-half method, and the validity was reached by the correlation to the tests: Complex Rey Pictures (Picture A) and subtests Cubes and Object Assembly of WAIS-III. Item analysis was also done to determine their difficulty. The sample was composed by 969 adults of both sexes, being (53.5\%) women and (46.5\%) men, with ages varying from 18 to 82 years old, who were divided in six subgroups, and school level ranging from elementary to college education. Results of the Variance Analysis indicated the existence of significant differences $(p \leq 0.05)$ between sexes, ages and school level, as well as in all interactions among these three variables. The Tukey Pos Hoc tests indicated differences among the averages of the three levels of education, an assemblage of ages in four groups. The $t$ tests pointed differences between the sexes only at 61 year old or more groups and for the high school level, men being superior. Norms were established in percentile according to the education level and age for the total sample and, separated for each sex, for high school and for the ages of 61 or more. The retest reliability indicated high correlation (0.897) among the results of the two test administrations. The split-half reliability between even and odd items, corrected by the Spearman-Brown formula was of 0.884 . The validity 
coefficients with other tests that assess the visual perception organization were significant (between 0.302 and 0.543). The analysis of the items difficulty showed the need of reordering the items according to their difficulty, as well as the need of reviewing the scoring criteria of some items, because in some cases, it will be necessary to review the answers which are scored as 1 or 0.5 points. It is also proposed a new order to present the items in the test administration. Therefore the standards established in this research, as well as the reliability and the validity data may allow the use of Hooper Test for our population, providing safe criteria for assist in the diagnosis of patients with complaints related to neural diseases.

Key words: Hooper Test, Visual Perception, Neuropsychological Evaluation, Visual Disorders. 


\section{LISTA DE ILUSTRAÇÕES}

Figura 1 - Teoria de Marr .53

Figura 2 - Teoria de Biederman Conjunto de componentes "Geons". .55

Figura 3 - Exemplo de "boa" forma ou simplicidade. .63

Figura 4 -Exemplo de unidade da forma .63

Figura 5 - Exemplo de segregação. .64

Figura 6 - Exemplo de proximidade. .65

Figura 7 - Exemplo de continuidade. .65

Figura 8 - Exemplo de fechamento 66

Figura 9 - Exemplo de semelhança 66

Figura 10 - Mapa citoarquitetônico de Brodmann. 71

Figura 11 - Gráfico de Porcentagem de acertos, acertos parciais e omissão de resposta.

Figura 12 - Histograma do total de pontos do piloto do Hooper. .121

Figura 13 - Histograma do total de pontos da amostra de padronização. 126

Figura 14 - Comparação da ordem original dos itens com a reordenada. 148 


\section{LISTA DE TABELAS}

Tabela 1 - Áreas de Broadmann relacionadas à percepção visual. .72

Tabela 2 - Distribuição de frequência da amostra piloto por idade e sexo.

Tabela 3 - Distribuição de frequência da amostra por idade e escolaridade

Tabela 4 - Distribuição da amostra em função da escolaridade e do sexo.

Tabela 5 - Distribuição da amostra em função faixa etária e do sexo

Tabela 6 - Distribuição de frequência por escolaridade, sexo e faixa etária.

Tabela 7 - Distribuição da amostra do reteste por Escolaridade e sexo....115

Tabela 8 - Distribuição da amostra de validade por sexo e escolaridade .116

Tabela 9 - Porcentagem das pontuações obtidas para acertos (1), acertos parciais $(0,5)$ e omissões, por item no piloto

Tabela 10 - Estatísticas descritivas de pontos por faixa etária do Hooper...... 122

Tabela 11 - Análise de variância do total de pontos por idade, sexo e escolaridade

Tabela 12 - Teste Post Hoc de Tukey por idade .123

Tabela 13 - Teste Post Hoc de Tukey por escolaridade 123 
Tabela 14 - Porcentagem de acertos (A) e correlações item total ( $\mathrm{r}$ i-t) para cada item do piloto

Tabela 15 - Análise de Variância por sexo, idade e escolaridade. 127

Tabela 16 -Teste de Tukey para escolaridade

Tabela 17 - Teste de Tukey HSD para Idade .128

Tabela 18 - Médias, Desvios padrão e teste $t$ por escolaridade entre os sexos

Tabela 19 - Médias, Desvios padrão e teste $t$ por idade entre os sexos 129

Tabela 20 -Médias, Desvios-Padrão e Percentis em função da escolaridade e para a amostra total para São Paulo. 130

Tabela 21 - Médias, Desvios-Padrão em função da faixa etária para São Paulo. 131

Tabela 22 - Médias, Desvios-Padrão e Percentis por sexo para.o .132 ensino superior e 61 anos ou mais

Tabela 23 - Médias e desvios padrão dos pontos, correlação e .133 e testes $t$

Tabela 24 - Correlação (r) entre o teste e o reteste para cada item 133

Tabela 25 - Correlações entre os pontos brutos do Hooper e. os demais testes

Tabela 26 - Correlações entre os demais testes $(\mathrm{N}=54)$. .136 
Tabela 27 - Porcentagem de pontos de cada item para a amostra total

Tabela 28 -Porcentagem de pontos de cada item por nível de escolaridade. 138

Tabela 29 - Correlação item-total para os 30 itens 139

Tabela 30 - Comparação entre a ordem original e a nova ordem dos itens em função da dificuldade. 


\section{LISTA DE SIGLAS}
APA
Associação Americana de Psicologia
CFP
Conselho Federal de Psicologia
CRP
Conselho Regional de Psicologia 


\section{INFORMAÇÃO IMPORTANTE}

O Código de Ética Profissional publicado em agosto de 2005, estabelece as responsabilidades do Psicólogo:

-Artigo $1^{\circ}$ (deveres fundamentais dos Psicólogos) Alínea i, estabelece que cabe a todo psicólogo "zelar para que a comercialização, aquisição, doação, empréstimo, guarda e forma de divulgação do material privativo do psicólogo sejam feitas conforme os princípios deste código";

-Artigo $15^{\circ}$, determina que o psicólogo deverá "zelar pelo destino dos seus arquivos pessoais, inclusive todo material psicológicos (testes)" e

-Artigo $18^{\circ}$ estabelece que: "o Psicólogo não divulgará, ensinará, cederá, emprestará ou venderá a leigos instrumentos e técnicas psicológicas, que permitam e facilitem o exercício ilegal da profissão". .

Por este motivo, a presente versão foi reduzida para ser disponibilizada na internet. Impedindo a possibilidade de leigos se apropriarem de informações referente ao Teste Hooper de Organização Visual e de utilizá-lo de forma ilegal. A versão completa da Tese, encontra-se na biblioteca do Instituto de Psicologia da Universidade de São Paulo (USP). 


\section{SUMÁRIO}

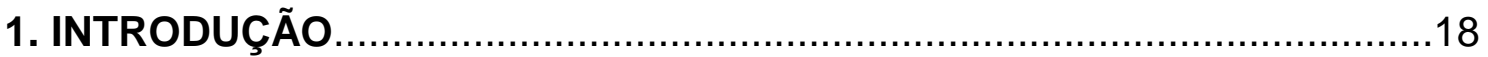

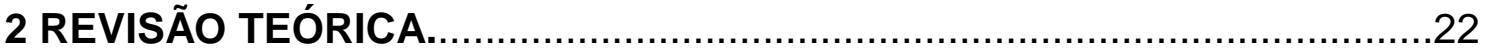

2.1.UMA BREVE HISTÓRIA DOS TESTES PSICOLÓGICOS ........................22

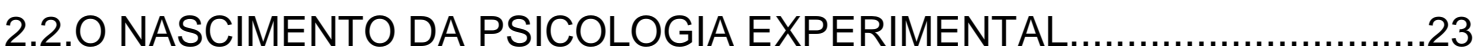

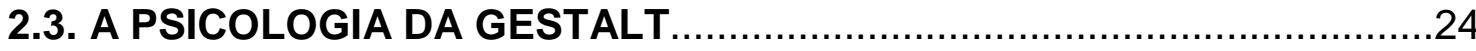

2.3.1 SENSAÇÃO E PERCEPÇÃO PARA A PSICOLOGIA GESTALT ............26

3. PRINCÍPIOS DA PSICOFÍSICA E DA FISIOLOGIA SENSORIAL .............28

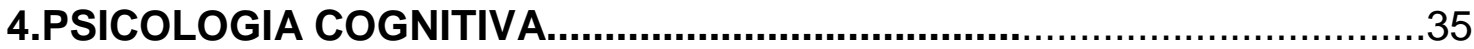

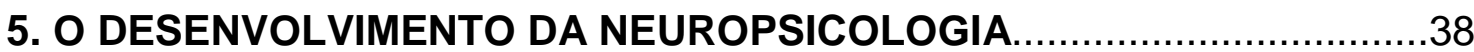

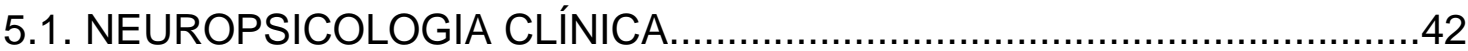

5.1.1 CONTRIBUIÇÃO DAS TÉCNICAS DE IMAGEM CEREBRAI PARA A

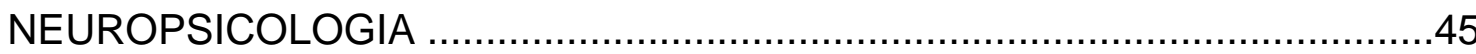

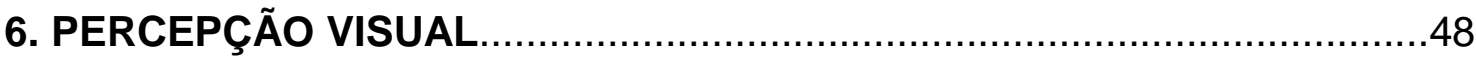

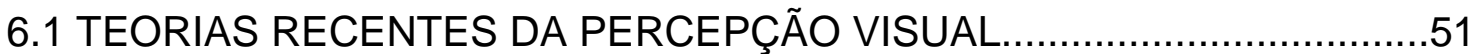

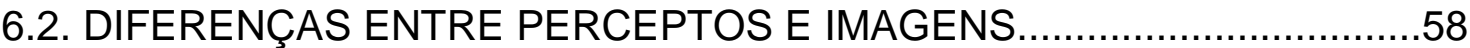

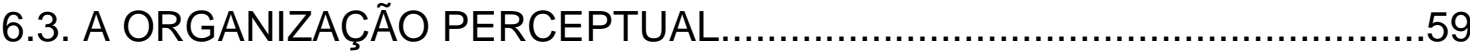

6.3.1 PRINCÍPIOS FUNDAMENTAIS OU LEIS DE ORGANIZAÇÃO DA FORMA

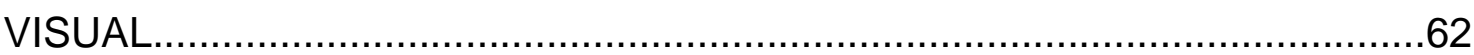

7. FUNÇÃO VISOESPACIAL E VISOCONSTRUTIVA...........................67

8 NEUROBIOLOGIA DA PERCEPÇÃO VISUAL ......................................70

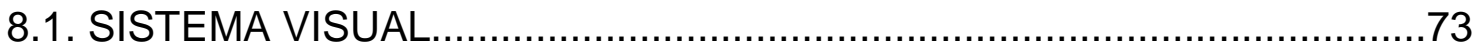

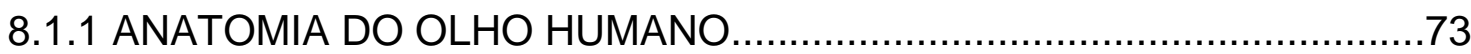

8.1.2 FATORES QUE INTERFEREM NA QUALIDADE DA IMAGEM ............75

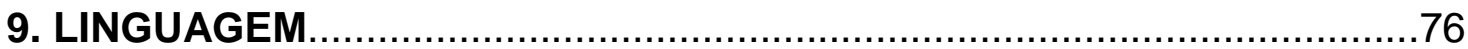

9.1 A POLISSEMIA E A HOMONÍMIA: IMPLICAÇÃO PARA A

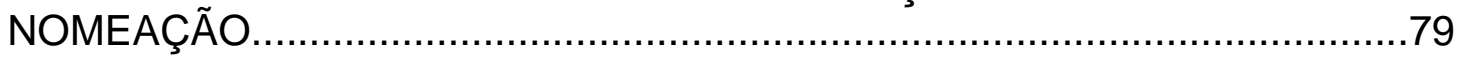

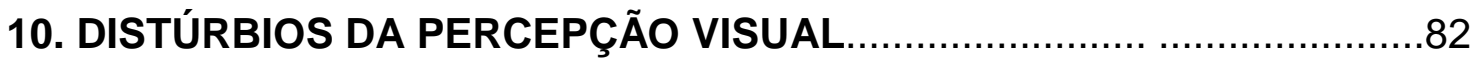

11. TESTES QUE AVALIAM AS FUNÇÕES VISOESPACIAIS E VISOCONSTRUTIVAS.............................................................................. 88 
12. O TESTE HOOPER DE ORGANIZAÇÃO VISUAL....................................90

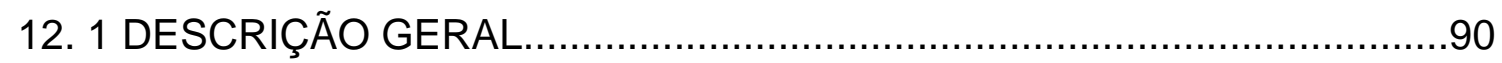

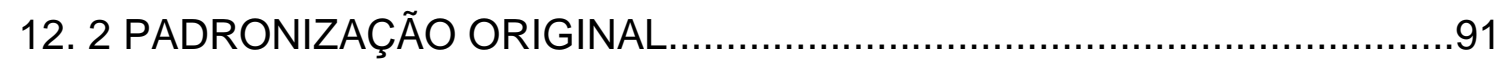

12.3 ESTUDOS DE PRECISÃO E VALIDADE DO VOT ...................................93

12.4 ANÁLISE QUALITATIVA DOS ERROS NO TESTE DE HOOPER..........104

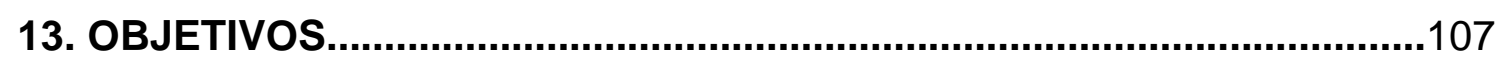

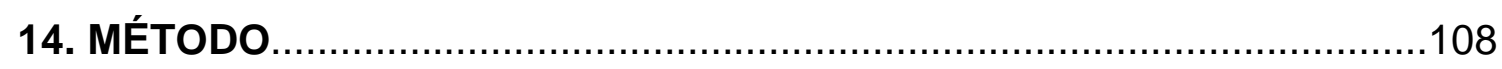

14.1.PESQUISA PILOTO

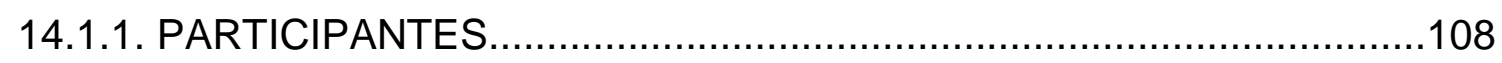

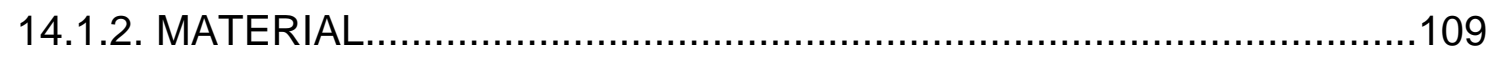

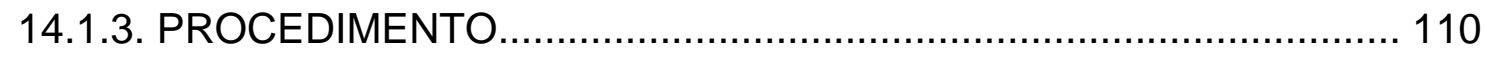

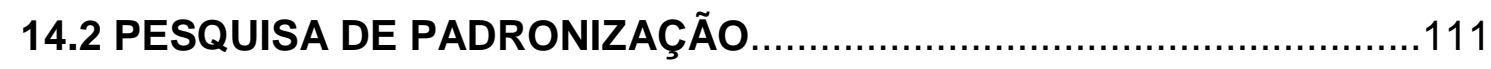

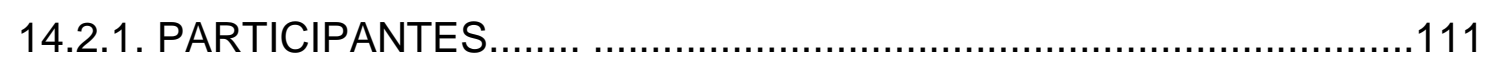

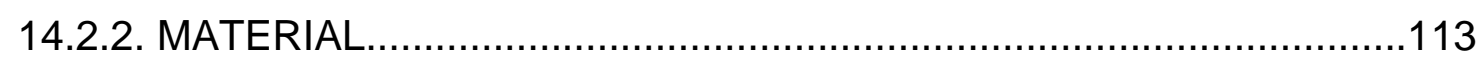

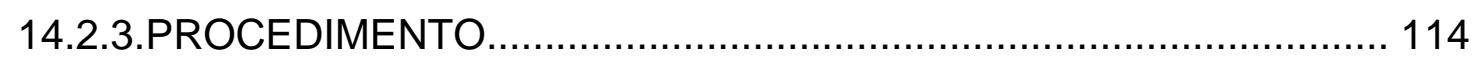

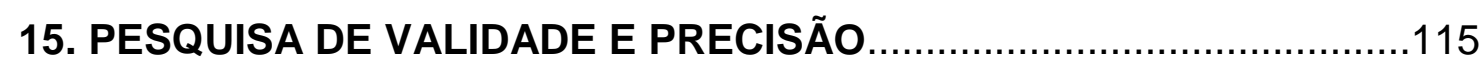

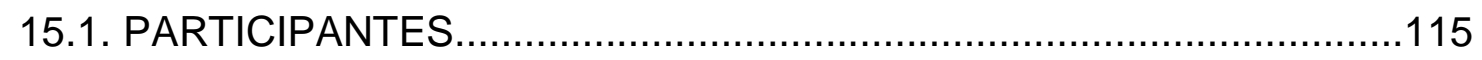

15.2. MATERIAL

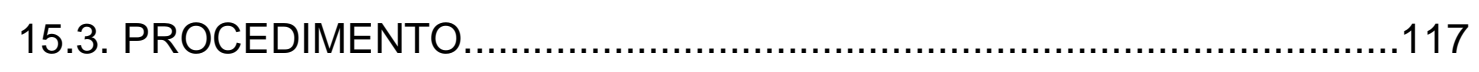

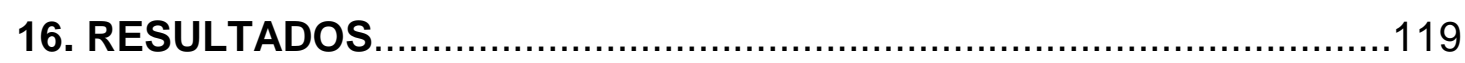

16.1. RESULTADOS DA PESQUISA PILOTO........................................119

16.2. RESULTADOS DA PESQUISA DE PADRONIZAÇÃO.......................125

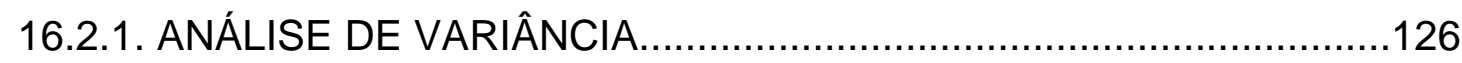

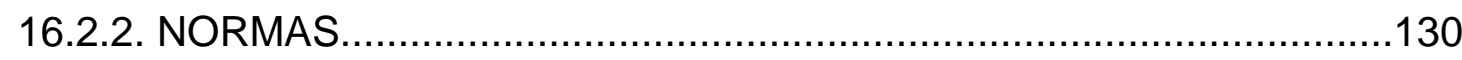

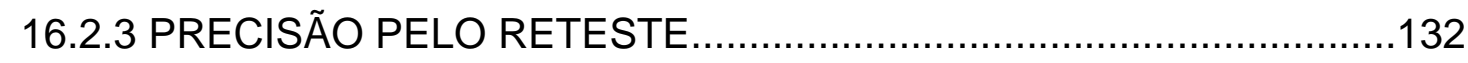

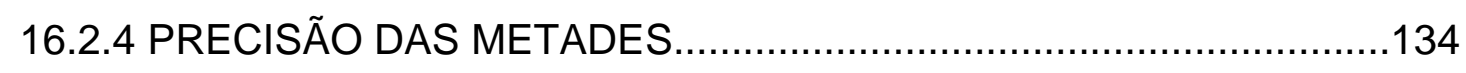

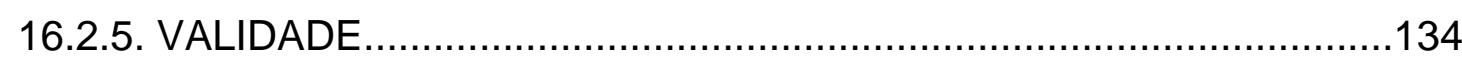

17. DISCUSSÃO

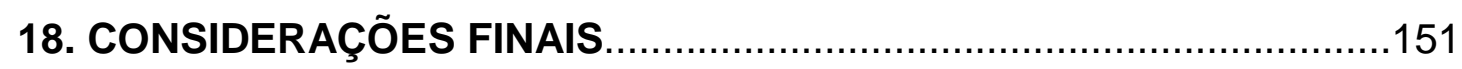

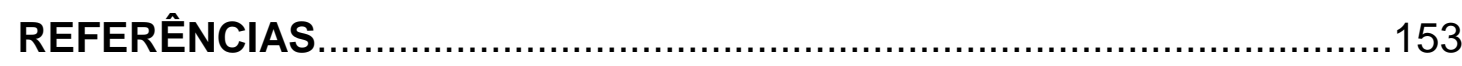

APÊNDICES 


\section{INTRODUÇÃO}

O sistema perceptivo é extremamente organizado e as atividades cerebrais são realizadas por células nervosas que se comunicam e se interrelacionam, visto que a relação do cérebro com o mundo é uma via de mão dupla, na qual o mundo constrói o cérebro e o cérebro constrói o mundo. Os efeitos da experiência sobre os mecanismos do sistema nervoso mostram que o cérebro é plástico, isto é, sujeito às alterações constantes em sua estrutura, nas suas conexões e nas funções das células que o compõem. A captação e a condução das informações sensoriais passam por um processo de reconhecimento do estímulo. Para isso, o cérebro faz o rastreamento de todos os atributos do estímulo considerando uma gama de informações previamente armazenadas sob a forma de memórias, que auxiliam na identificação. A busca das informações é feita utilizando um processamento por vias paralelas e específicas que se intercomunicam (Damásio, 2000; Squire et al., 2008).

A experiência maravilhosa, em um ato aparentemente "simples" de perceber, não está só nas sofisticadas engrenagens dos mecanismos neurobiológicos, mas também na singularidade daquele que a percebe ou,como disse um dos grandes pioneiros da Psicologia do século $X X$, James (citado por Wertheimer, 1991, p. 111),"nunca dois estímulos ou dois estados da consciência são idênticos".

Wertheimer também enfatiza que o crescente estudo no campo da percepção permitiu à Psicologia e às demais ciências compreenderem 0 contexto mais amplo dos processos cognitivos e as suas relações. Os elementos relacionados à sensação humana foram a porta de entrada para muitos questionamentos filosóficos e científicos em relação à natureza da "mente humana e do aprendizado", fato que até hoje gera muitas discussões sobre os conceitos de mente e cérebro entre tais estudiosos. A Psicologia Experimental se interessou pela sensação e pelos fenômenos provocados pelas contingências do meio ambiente como objetos do seu estudo, a fim de tentar entender os processos mentais internos. A Psicologia da Gestalt contribuiu para o estudo da percepção, utilizando o conceito da qualidade da forma, que era considerada como um elemento acima dos elementos que 
compõem um conjunto, e o método fenomenológico foi fundamental para este estudo (Wertheimer, 1991).

Atualmente, com o avanço da tecnologia por imagem do cérebro, muitas questões sobre as suas áreas e o seu funcionamento puderam ser respondidas. A Neurociência tornou-se um campo sólido de interesses em comum com muitas vertentes científicas e várias abordagens sobre 0 desenvolvimento são usadas para compreender os fenômenos perceptivos, os da atenção, da memória, da linguagem, das habilidades motoras, assim como de outros processos cognitivos superiores (Gazzaniga, Ivry \& Mangun, 2006).

Do mesmo modo que as demais ciências, a Psicologia também passou por reformulações em seus conceitos teóricos sobre os processos mentais. E, dentre as suas ramificações, foi a Psicologia Cognitiva que trouxe a compreensão de que as atividades cognitivas e os estágios de processamento das funções cerebrais poderiam ser analisados considerando o intercâmbio entre os seus componentes.

Porém, segundo Anastasi (1977), os primeiros psicólogos experimentais do século XIX não mostravam interesse em medir as diferenças individuais. De fato, o que realmente interessava a eles eram os aspectos do comportamento que poderiam ser generalizados. De qualquer forma, foram estes psicólogos que muito contribuíram para a organização dos primeiros testes psicológicos em relação à necessidade de um controle rigoroso nas observações dos fenômenos comportamentais.

No século $X X$ houve um grande avanço no desenvolvimento das ciências de modo geral, em especial nas ciências do cérebro, sendo a Psicologia uma delas. Os testes psicológicos também se desenvolveram desde então, sendo modernizados com inúmeras modificações e adaptações.

No Brasil, o desenvolvimento de instrumentos para avaliação psicológica e neuropsicológica vem aumentando significativamente, dada a sua importância para os processos diagnósticos, tanto o de prevenção quanto o de tratamento. Até pouco tempo em nosso país não havia uma exigência de padronização para a população brasileira para o uso de testes psicológicos, pois eram utilizados, além dos testes desenvolvidos e padronizados no Brasil, outros com normas de outros países. Porém, em 2003, o Conselho Federal de 
Psicologia tomou medidas mais rigorosas em relação à utilização dos testes, tornando permitido apenas os que atendem todas as especificações referentes à padronização para o Brasil. De fato, é importante considerar as questões sociais e culturais de uma determinada população, visto que tais elementos podem alterar de forma significativa os resultados de uma avaliação e, como consequência, não refletir a realidade da pessoa que está sendo avaliada. A diversidade étnica, sociocultural e econômica deve ser considerada para a construção dos padrões nos testes com critérios relativos às características da população em que vai ser avaliada. É também relevante a uniformidade dos procedimentos da administração e avaliação dos testes para uma maior confiança nos resultados (Anastasi, 1977; Urbina, 2007).

Segundo Alves (1998), algumas variáveis como o nível socioeconômico, a idade, o sexo e o grau de escolaridade têm mostrado uma influência significativa nos resultados dos testes, entre os quais citou o Teste de Goodenough, as Matrizes Progressivas Coloridas de Raven, a Escala de Maturidade Mental Colúmbia, o Teste R-1 e o Teste D.70.

A presente pesquisa pretende empreender a normatização e a padronização do Teste Hooper de Organização Visual (Hooper Visual Organization Teste - VOT) para a população brasileira. Este teste foi publicado por $\mathrm{H}$. Elston Hooper em 1958 e revisado em 1983. Trata-se de um instrumento que pode ser utilizado para avaliar a capacidade de crianças, adultos e idosos de organizar mentalmente estímulos visuais. Para um desempenho eficiente neste teste, é necessário o envolvimento de mecanismos altamente sofisticados do sistema nervoso central operando de forma simultânea e harmoniosa. Assim, a tarefa neste tipo de teste é particularmente sensível a prejuízos neurológicos. Portanto, pode-se afirmar que é um instrumento valioso na investigação clínica, podendo ser administrado para triagem, bem como para complementar a avaliação em baterias de testes psicológicos.

A Neuropsicologia no Brasil é uma área ainda muito jovem e, portanto, pouco conhecida, até mesmo por muitos psicólogos, o que leva à escassez de instrumentos psicológicos padronizados para a população brasileira. A autora deste trabalho atua na área clínica, especificamente na avaliação neuropsicológica e se interessou em colaborar para a adaptação e 
padronização brasileira do VOT. O uso deste teste é importante como recurso complementar para as investigações neuropsicológicas por causa de sua estrutura, semelhante ao subteste Armar Objetos da Escala WISC ou da WAIS (Wechsler,1997), em que as figuras são divididas em partes, como um quebracabeça. Contudo, diferentemente deste teste, não permite ao examinando juntar as peças com as mãos, já que as partes das figuras são apresentadas impressas em um cartão. Dessa forma, proporciona um exame mais minucioso de outros aspectos que poderiam estar interferindo no desempenho geral de tarefas de discriminação visual. Além disso, constitui um teste rápido, de fácil aplicação, avaliação e interpretação. 


\section{REVISÃO TEÓRICA}

\subsection{UMA BREVE HISTÓRIA DOS TESTES PSICOLÓGICOS}

Antes de discorrer sobre a história dos testes psicológicos é importante entender a sua definição e classificação. De acordo com Urbina (2007), "o teste psicológico é um procedimento sistemático para obtenção de amostras de comportamento relevantes para o funcionamento cognitivo ou afetivo, bem como para a avaliação destas amostras de acordo com certos padrões" (p.1112). Entre os testes psicológicos estão os de inteligência, que avaliam os conhecimentos adquiridos ou qualquer outra função cognitiva, e os testes de personalidade.

Segundo Anastasi (1977), Dubois relatou que os testes psicológicos já eram utilizados desde a antiguidade, porém, foi a partir do século XIX que houve um desenvolvimento mais representativo dos mesmos. Nessa época, ocorreu um crescente interesse no tratamento dos portadores de doença mental. Deste modo, era imprescindível o desenvolvimento de meios que permitissem uma avaliação mais criteriosa para a identificação e classificação dos indivíduos suspeitos de possuírem tais características. Além disso, se fazia necessário distinguir o débil mental do doente mental. O primeiro autor que escreveu sobre esta distinção foi Esquirol, em 1838, e foi ele que desenvolveu um sistema de classificação dos diferentes graus e variações da debilidade mental, concluindo que o critério mais seguro para alcançar esse objetivo era pelo uso da linguagem. Seguin foi o pioneiro na educação de "débeis" mentais e também teve importante contribuição, visto que desenvolveu técnicas para exercícios intensivos de discriminação sensorial e do controle motor, sendo que alguns destes processos foram posteriormente incorporados aos testes de inteligência não verbal ou de execução. Outros autores, como Wundt (1879), estavam mais preocupados com as descrições gerais do comportamento.

Os precursores da Psicologia Experimental possuíam formação mais relacionada ao campo da Fisiologia e da Física e seus estudos eram mais direcionados à sensibilidade, aos estímulos visuais, auditivos e sensoriais e ao tempo de reação. Diante do desenvolvimento dos testes psicológicos, surgiu a necessidade de criar métodos que levassem a um controle e a uma 
observação mais rigorosa. Deste modo, os testes passaram a ter formas padronizadas de aplicação. Entre os estudiosos que contribuíram para o desenvolvimento dos testes psicológicos estava o biólogo Galton (1879), que foi responsável pelo início da aplicação dos testes e que também colaborou para o desenvolvimento de métodos e escalas de avaliação, de questionários e a técnica de "associação livre", além do desenvolvimento dos métodos estatísticos. Por sua vez, Cattell (1890) usou pela primeira vez o termo "teste mental" e mostrou interesse pela mensuração de diferenças individuais, enquanto Binet (citado por Anastasi,1977) se dedicou durante muitos anos à mensuração da inteligência.

Urbina (2007) relata que atualmente os testes estão mais sofisticados em termos metodológicos, além de apresentarem embasamento mais consistente do que no passado.

\subsection{O NASCIMENTO DA PSICOLOGIA EXPERIMENTAL}

O primeiro laboratório de Psicologia Experimental foi inaugurado em 1879 e cientistas como Wundt, Fechner e James contribuíram para que ela ganhasse o status de ciência. Porém, outros anteriores a Wundt também se destacaram (Wertheimer, 1991).

A Psicologia Experimental integrou conhecimentos de duas áreas fundamentais, sendo uma delas a Ciência - com todo o seu rigor - e a Filosofia. A Ciência tinha como bases a Fisiologia e a Biologia, com abordagem atomista $^{1}$ e recursos visando a quantificação e a precisão nos processos investigativos, além de promover a pesquisa a nível universitário com 0 desenvolvimento de laboratórios específicos para este fim. A contribuição

\footnotetext{
${ }^{1} \mathrm{Na}$ abordagem atomista de Demócrito 400 a.C., tudo seria composto por átomos, materiais indivisíveis e unitários que se encontrariam em movimento constante, sendo as pessoas compostas por átomos de alma e por átomos de corpo. Neste pressuposto, há a tendência para o reducionismo, no qual toda existência seria reduzida aos átomos. Além disso, os estímulos externos teriam grande importância na determinação do comportamento do indivíduo, levantando a questão do que poderia controlá-lo, as forças externas ou o livre arbítrio (Wertheimer, 1991).
} 
recebida da Filosofia foi o empirismo crítico, o associacionismo e o materialismo científico.

Muitos estudos foram realizados em Fisiologia a respeito dos órgãos do sentido, que mais tarde foram conhecidos como processos neurofisiológicos. $\mathrm{O}$ corpo humano exercia grande fascinação. Assim sendo, surgiu o interesse de estudá-lo de forma mais detalhada, explorando suas partes e funções.

A abordagem atomista tinha boa aceitação entre as disciplinas da época, e a jovem Psicologia também não ficou de fora. Dalton utilizou a teoria atômica para a classificação dos elementos químicos. Aliás, foi esse autor quem ofereceu grande contribuição à Psicologia com informações sobre a cegueira em relação às cores (daltonismo), visto que ele próprio tinha esse problema (Wertheimer, 1991).

A Biologia influenciou a Psicologia com o conceito de evolução. $\mathrm{Na}$ Neurofisiologia havia sido desenvolvida a teoria do neurônio por Santiago Ramón y Cajal. Além disso, muitos filósofos tinham uma visão influenciada pela abordagem atomista para os fatos mentais. Nessa época tiveram início os estudos que mostravam muito interesse na relação entre o cérebro e a mente, sendo a Psicologia da Gestalt um deles (Wertheimer, 1991).

\subsection{A PSICOLOGIA DA GESTALT}

Segundo Wertheimer (1991), a Gestalt ou Psicologia da Forma é a teoria que estuda os processos relacionados à percepção visual. A escola da Gestalt foi fundada por Wertheimer (1880-1943), Koffka (1886-1941) e Köhler (18871967). A proposição original foi baseada nas ideias de Wertheimer e elaborada posteriormente pelos outros dois fundadores, que também contaram com a colaboração de Lewin (1890-1947). Outra influência foram as ideias de Kant, que sustentava a concepção de que a percepção reflete uma capacidade inata do cérebro de organizar simples sensações de maneiras características.

Os contrapontos entre as outras teorias da Psicologia e a Gestal se relacionavam ao tema da descoberta do mundo pela mente humana e a partir desta questão surgiram diversas explicações sobre os fenômenos subjetivos e 
objetivos implicados. A Psicologia da Gestalt ${ }^{2}$ era contrária às correntes atomistas e associacionistas, sendo estas o Estruturalismo, o Funcionalismo e o Behaviorismo. O início da história da Teoria da Gestalt ocorreu com a proposição original de Wertheimer, por volta de 1910, quando observou o movimento e percebeu que o estímulo visual descontínuo poderia produzir a percepção de movimento contínuo. Assim, a percepção não corresponderia ponto a ponto ao estímulo físico, mas se organizaria como um todo, porém, este todo percebido não seria a soma das partes que o compõem.

Os gestaltistas não concordavam com a hipótese proposta pelos estruturalistas, que consideravam que a relação entre estímulo local e percepção é constante. Para a Teoria da Gestalt ao contrário, há um dinamismo na percepção em que as qualidades do todo determinam as características das partes, sendo uma parte determinada pelo seu lugar, papel e função em relação ao todo no qual está inserida.

Conforme Wertheimer (1924, citado por Engelmann, 2002), as gestalten são essencialmente diferentes das sensações. A gestalt precede a existência das partes, já que primeiro é visto o todo e, só depois, as partes são percebidas. Trata-se de uma proposta que mostra o inverso do que era explicado anteriormente pela teoria clássica de Helmholtz (1821-1894) e Wundt (1832-1920) ao descreverem uma experiência perceptiva.

Köhler (1968) sugeriu que, embora houvesse uma interdependência dinâmica geral em relação a todo campo perceptivo, existem limites, nos quais os fatores dinâmicos atuariam para uma determinada medida de segregação e não de continuidade uniforme como foi proposto por James. Descreveu que o campo visual apresentaria duas espécies de ordens, sendo uma delas a ordem ocupada pela teoria mecanicista (manutenção de um determinado processo entre os demais) e outra em que, na maior parte dos campos visuais, os conteúdos de áreas particulares seriam de mesma classe, funcionando como unidades restritas, nas quais o meio ambiente seria excluído.

Deste modo, o autor chamou a atenção para o fato de que James, em sua análise, não havia considerado a possibilidade de que um dos elementos de organização do campo seria inerente a um fator de ordem sensorial, pois a 
sua proposição continha pressupostos empíricos. No entanto, existia concordância entre os autores em relação à participação da experiência na organização sensorial, no que se refere à utilidade, à nomeação e ao significado dos objetos, que estariam sujeitos à experiência cultural prévia. Contudo, os gestaltistas iam além e consideravam que no sistema nervoso havia mecanismos orgânicos que permitiriam a percepção de um objeto sem que houvesse a necessidade de experiência prévia, pois, embora o objeto pudesse ser desconhecido, ainda assim não era confundido com o meio ambiente. Portanto, as unidades sensoriais, que permitiriam a percepção do objeto, já teriam por si só uma estruturação subjacente.

Os estímulos, como as cores, os sons, os cheiros, as texturas, etc., com as suas características consideradas como primárias e pertencentes ao "mundo real" poderiam ser diferenciadas das qualidades secundárias (subjetivas). Mas, considerando que as características primárias dos estímulos necessitavam ser interpretadas pelo sistema sensorial, elas também se tornavam subjetivas, já que dependeriam da inferência do organismo. Tal pressuposto constituiu-se no paradigma sugerido pelos gestaltistas para refutar as ideias do instrospeccionismo, visto que os gestaltistas concebiam o meio experimentado pelo homem como resultado interpretativo do cérebro (Köhler, 1968).

\subsubsection{SENSAÇÃO E PERCEPÇÃO PARA A PSICOLOGIA DA GESTALT}

A diferença entre a Teoria Introspeccionista e a Psicologia da Gestalt consistia na concepção de como a experiência deveria ser observada. As premissas do introspeccionismo eram consideradas muito parecidas com as do behaviorismo. Para tanto, foi enfatizada a importância da distinção entre o conceito de sensação (mera resposta sensorial ao estímulo) e o de percepção (conjunto de conceitos ao qual o estímulo está associado em consequência da aprendizagem). Os adeptos do introspeccionismo relatavam que não se poderia dizer o que se vê com base no que se aprende, pois isso implicaria em conhecimento prévio a respeito da classe, espécie e utilização dos objetos. Contudo, o argumento gestaltista afirmou que a pura utilização da visão não 
implicaria por si só em conhecimento do objeto, mas sim em simples sensações. Dessa forma, a existência de um objeto em relação à semântica somente seria possível quando acompanhado da experiência sensorial associada à significação cultural (Köhler, 1968).

Neste contexto, pode ser compreendida a existência de maior complexidade de relações e, portanto, da inferência dos mecanismos da percepção. E que, se todos os fenômenos que podem ser descritos fossem produtos da experiência previamente adquirida, então em uma análise introspectiva seria possível deduzir que todos estes fenômenos não são fatos reais e, portanto, estariam desprovidos de significação psicológica. Diante desta questão foi postulado que as hipóteses gestaltistas eram contrárias aos pressupostos introspecionistas, visto que a primeira teoria considerava a experiência sensorial (sensação) associada a um conhecimento adquirido (percepção) tão importante quanto uma experiência que não tenha tido tal influência. Foi destacada a existência de duas espécies de fenômenos, um decorrente da experiência e outro ainda não explicado, que seria proveniente dos mecanismos do sistema nervoso.

Pode-se considerar como exemplo o símbolo (+), aprendido desde a infância e relacionado ao sinal de adição nas operações matemáticas. Quando é visto entre números é percebido como sinal de adição em função dos significados estabelecidos pela cultura, porém o estímulo formado por dois traços, um em posição horizontal e o outro na vertical, também poderia ser percebido como uma cruz em sentido religioso ou até mesmo possuir qualquer outro significado. No entanto, o estímulo apenas visto, sem associações prévias, será sempre o mesmo. Neste sentido, ocorrem dois fenômenos defendidos pela Gestalt: o primeiro é a experiência proveniente da aprendizagem; o segundo é um fenômeno da experiência sensorial, os quais juntos permitem perceber de modo peculiar em um dado contexto.

Desse modo, foi defendida a ideia de que a experiência direta em si mesma não seria totalmente possível, pois consistiria na definição de critérios seletivos para que uma experiência sensorial pudesse ser considerada como puramente sensorial. Por exemplo, embora a velocidade retiniana seja diferente em relação à distância de um determinado estímulo visual estando 
este a 10 ou a cinco metros ainda assim, a velocidade seria percebida como semelhante. O mesmo ocorre para a constância de tamanho, forma e brilho dos estímulos, temas de interesse da Psicofísica.

\section{PRINCÍPIOS DA PSICOFÍSICA E DA FISIOLOGIA SENSORIAL}

O estudo da percepção no homem sempre remeteu a questões de grande complexidade relativas à subjetividade humana, visto que as experiências sensoriais estavam relacionadas às experiências individuais. Portanto, alguns pesquisadores passaram a se dedicar mais ao estudo das experiências sensoriais subjetivas, denominado Psicofísica (Dudel, 1980). Compreende-se a Psicofísica como uma das áreas da Psicologia que estuda a relação entre a percepção de um estímulo e as dimensões físicas do estímulo percebido (Goodwin, 2005; Squire, et. al., 2008). A Fisiologia Sensorial é um ramo das ciências naturais relativo aos princípios que regem os órgãos dos sentidos, a sua organização e o seu funcionamento, bem como as suas conexões com o sistema nervoso central. Ocupa-se dos fenômenos pautados nos aspectos biológicos concernentes à percepção dos seres vivos. Considera os receptores sensoriais como pontos de contato entre os estímulos e o sistema nervoso, que permite a captação e a transdução ${ }^{3}$ de todo tipo de estímulos ambientais (Rodrigues, 2010).

A relação entre a localização do estímulo e a ativação de determinados neurônios sensoriais é o principal tema da Fisiologia Sensorial (Koeppen \& Stanton, 2009). A detecção sensorial é o processo pelo qual os neurônios convertem a energia ambiental em sinais neurais. São ativados neurônios especiais, chamados receptores sensoriais. Podem ser sentidas as mais variadas formas de energia, como: a mecânica, a luminosa, a sonora, a química, a térmica e a elétrica.

\footnotetext{
${ }^{3}$ Transdução em biologia é um processo pelo qual uma célula converte um tipo de sinal ou estímulo em outro. Fonte: http://pt.wikipedia.org/wiki/Transdução_de_sinal. Acesso em: 20/04/2015
} 
De acordo com a Fisiologia Sensorial, o estímulo limiar é o estímulo mais fraco que pode ser identificado. Para isso, um estímulo deve produzir potenciais de intensidade suficientes para ativar uma ou mais fibras aferentes primárias. Os mais fracos podem produzir potenciais subliminares no receptor, mas não são transmitidas aos neurônios sensoriais centrais e, deste modo, não podem ser percebidos. Ademais, os neurônios aferentes primários que devem ser excitados dependem das exigências para a estimulação espacial e temporal. O campo receptivo do neurônio sensorial é a região que, quando estimulada, afeta o seu comportamento. Os neurônios sensoriais codificam os estímulos. No processo de transdução sensorial, um ou mais aspectos do estímulo devem ser codificados de modo que possam ser interpretados pelo SNC, tais como a modalidade sensorial, a localização espacial, o limiar, a intensidade, a frequência e a duração. Uma modalidade sensorial é uma classe de sensações imediatamente identificáveis, como, por exemplo, as táteis, visuais, auditivas, do paladar, do olfato, da posição espacial, entre outras (Guyton \& Hall, 2012; Koeppen \& Stanton, 2009).

$\mathrm{Na}$ época em que a Psicofísica despontava, a Fisiologia Sensorial era baseada apenas no fenômeno subjetivo, isto é, na percepção. Não eram considerados ainda os mecanismos neurais envolvendo os potenciais elétricos registrados em receptores sensoriais. Fechner, então, criou o conceito de Psicofísica Interna para se referir às funções neurais ou às relações sensoriais e às respectivas atividades neurais. Ainda que ele não tivesse um conhecimento profundo das atribuições neuronais, entendia que tinham parte importante na compreensão desta relação entre o mundo objetivo e o subjetivo. Assim, Fechner considerava como Psicofísica Externa a relação entre as sensações (ou seja, o fenômeno) e as correspondentes propriedades físicas, como também as variações dos próprios objetos (Scheerer, 1992, citado por Costa, 2010).

Os estudos em Psicofísica tiveram a contribuição de Muller através da publicação do "Manual de Fisiologia", em que detalhava questões sobre a percepção, a sensação e de Weber, que realizou experimentos quantitativos em muitas modalidades sensoriais. Este estudou o limiar dos dois pontos, descobrindo importantes diferenças entre várias partes do corpo em relação à 
distância entre dois pontos tocados ao mesmo tempo para que fossem percebidos como um par e não apenas como um. Também se concentrou na diferença apenas perceptível (reação mínima para a percepção da alteração de um estímulo). Weber mostrou que não havia correspondência exata entre as alterações do mundo físico e as experiências psicológicas dessas alterações, ou seja, o aumento de um peso em 3 gramas nem sempre produziria a mesma sensação e, portanto, dependeria do estímulo padrão (EP) (Goodwin, 2005; Squire et al., 2008; Wertheimer, 1991).

As pesquisas de Weber sobre os limiares já eram conhecidas por Fechner. Entretanto, o insight sobre a sua importância para os fenômenos perceptivos só ocorreu em 1850. Ele observou que as sensações poderiam ser medidas partindo da suposição de que as diferenças minimamente perceptíveis (d.m.p.s) entre os estímulos poderiam ser percebidas como iguais em magnitude. Essa hipótese de igualdade subjetiva o levou a reformular a lei de Weber como $\mathbf{S}=\mathbf{k} \log \mathbf{R}$, em que $\mathbf{S}$ é a sensação, $k$ uma constante e $\mathrm{R}$ a medida física do estímulo. Fechner substituiu a d.m.p por $\mathrm{S}$, por ser considerada uma unidade de medida psicológica. Baseando-se nesta mudança ele desenvolveu uma escala que principiava no ponto em que a sensação era inicialmente percebida, que ele denominou limiar absoluto (So). À medida que a intensidade do estímulo cresce, ultrapassando este limiar, é experimentada uma diferença minimamente perceptível, seguida de outra e assim sucessivamente (Goodwin, 2005).

Os princípios básicos da Psicofísica foram descritos por Fechner em suas principais obras denominadas Elementos de Psicofísica, de 1860. Ele propôs uma equação para provar a relação entre a mente e o corpo, na qual mostrou que, na medida em que o estímulo aumentava linearmente, a intensidade da sensação também aumentava como logaritmo do estímulo. Seus experimentos e desenvolvimento de métodos psicofísicos contribuíram para a constituição de uma base de medida (Wertheimer, 1991).

Fechner formulou três importantes métodos, todos eles usando um estímulo padrão e um estímulo variável, que deveriam ser comparados e que são apresentados a seguir: 1) o método dos limites; 2) o método dos estímulos 
constantes; 3) o método de reprodução. Os três permitiram, pela primeira vez, medir as quantidades psicológicas de maneira precisa.

O estudo das relações entre os fenômenos físicos e mentais passou a fazer parte da Psicofísica e da Fisiologia Sensorial. Por outro lado, a Psicologia quantitativa e o surgimento da Estatística como disciplina tiveram grande impacto na primeira metade do século XIX, o que favoreceu a aceitação da Psicofísica e dos testes mentais (Wertheimer, 1991).

Os campos da Psicofísica tiveram origem na observação dos fundadores da Psicologia Experimental ao constatarem que, embora a recepção sensorial fosse diferente para cada um dos sentidos, existiam três etapas comuns a todos: 1) o estímulo físico; 2) a transformação do estímulo em impulsos nervosos; e 3) a percepção ou representação interna do estímulo. A Psicofísica buscou estudar as relações entre as características físicas de um estímulo e as qualidades de sua percepção, enquanto a Fisiologia Sensorial preocupou-se com as respostas neurais a um determinado estímulo físico, ou seja, o caminho percorrido pelo estímulo desde a transdução pelos receptores sensoriais até o processamento no cérebro (Kandel, Schwartz \& Jessell, 2000).

O grande dilema para os estudiosos da percepção sensorial sempre foi a relação do indivíduo com o estímulo, a subjetividade desta relação, já que ocorre uma identificação muito particular para cada um, o que é algo inerente às vivências pessoais íntimas advindas do ambiente onde o indivíduo está inserido e que podem estar vinculadas aos aspectos de ordem cultural, emocional e de humor, levando às diferenciações em relação à qualidade do estímulo percebido. Os aspectos psicológicos da Fisiologia dos sentidos são amplos e variados, isto é, também se deve considerar que um ambiente privado de estímulos sensoriais pode levar à instabilidade emocional e à doença psíquica. Com isso, as ciências naturais não podem responder sozinhas ao problema psicofísico relacionado à Fisiologia dos sentidos (Dudel, 1980).

O conhecimento do ambiente e das ocorrências que se passam no interior do organismo por meio dos órgãos dos sentidos especializados não é dado de forma global e imediata, mas por meio do processamento de cada órgão. Os órgãos sensoriais (da visão, da audição, tátil, gustativo e olfativo), 
estão adaptados para reagir à determinada sucessão de influências ambientais, assim como para transmitir as respectivas informações ao sistema nervoso central.

O conceito de impressão sensorial se refere às unidades fundamentais das experiências sensoriais, como a impressão da cor, do gosto ou cheiro de um determinado estímulo. Raramente as impressões sensoriais são recebidas isoladamente. O conjunto de impressões sensoriais recebe o nome de sensação e, da mesma forma, a sensação pura, se estiver acompanhada de uma interpretação baseada em fatos vividos ou aprendidos, é chamada de percepção (exemplo: carro verde e cheiro de perfume). Estas são, basicamente, as áreas de interesse da Psicofísica e da Fisiologia sensorial que prestam apoio para a compreensão de alguns dos fenômenos perceptivos, como, por exemplo, a percepção de profundidade e de distância (declive perceptual) (Dudel, 1980; Kandel, et. al., 2000).

Embora o mundo pareça ser tridimensional, a retina possui apenas duas dimensões. O julgamento de profundidade é uma forma de percepção de distância. Este fenômeno pôde ser comprovado em um estudo realizado com a utilização de um aparelho denominado "declive perceptual", composto por uma pesada placa de vidro colocada a alguns centímetros acima do piso de um cubículo. No sentido longitudinal da placa é colocada uma plataforma fina coberta com tecido quadriculado. De um lado da plataforma é disposto um pedaço do mesmo tecido, diretamente abaixo do vidro. Do outro lado, o tecido foi colado sobre o chão. Ao ser apresentado para crianças que já engatinhavam e animais, o primeiro lado parecia sólido, enquanto o outro era visto como um degrau, ou "declive". As crianças, assim como frangos, cabritos, cordeiros, ratos e gatos, pareciam perceber o "declive visual" como perigoso, evitando passar para o outro lado do vidro. Este estudo mostrou que a percepção de profundidade é muito importante para os seres humanos e animais, aparecendo como estrutura inata e aprendida pouco tempo após o nascimento (Gibson e Walk, 1960, p. 106, citado por Statt, 1978).

A percepção de movimento pode ser explicada pelos estímulos visuais passando por nosso campo visual, que impulsionam diferentes partes do olho. Há, entretanto, percepções de movimento ilusórias e que não são explicadas 
deste modo. A ilusão de movimento nos filmes é decorrente de uma série de fotografias, em que cada uma delas é levemente diferente da precedente, que é projetada numa tela em uma frequência de 20 quadros por segundo. Com esta velocidade não se percebe a série de imagens como fixas, mas sim o movimento que elas formam quando vistas em sequência. Este tipo de ilusão foi denominado de "Phi-fenômeno". Os pesquisadores perceberam que ao acender e apagar duas lâmpadas em rápida sucessão, dando um intervalo correto entre a apresentação dos dois estímulos, as pessoas teriam a impressão que as luzes estariam se movimentando de um ponto para o outro.

Koffka (1983), estudando algumas ilusões de ótica, destacou o que já havia sido comprovado anteriormente, que um processo perceptivo é determinado pela natureza do campo mais vasto em que ele ocorre. Outro exemplo dado pelo autor mostra que a direção do movimento percebido depende do campo circundante, conforme o resultado de estudos anteriores realizados por Stern. Se o campo é enquadrado ou articulado por linhas retas, o movimento é retilíneo; se a moldura ou articulação é curva, o movimento acompanha a forma e a direção das curvas.

Segundo Costa (2010), a Psicologia vem desenvolvendo métodos de medidas das sensações internas e das respostas perceptuais para os estímulos externos. Os estudos em Psicofísica buscam a determinação de um limiar. A Psicofísica também investiga os fenômenos relacionados à percepção das cores. Conforme Lima, Gomes, Ventura e Silveira (2011), a capacidade para a percepção dos objetos a partir do contraste de cores permite identificar e localizar padrões ambientais de mesmo brilho. Quando são acrescentadas maiores informações como luminância, contraste, forma, movimento, textura e profundidade, estas auxiliam a identificação dos objetos e sua distinção em relação à cena em que estão inseridos. A Psicofísica visual preocupa-se com o estudo quantitativo da relação entre os eventos físicos de estimulação sensorial e a resposta comportamental resultante desta estimulação, permite meios de avaliação de aspectos da visão humana, como a de cores.

Numerosos estudos psicofísicos atuais descreveram o aprendizado perceptual como melhorias na discriminação perceptual e na capacidade de detecção. As pesquisas envolvendo a localização e a plasticidade a longo 
prazo do cérebro foi fundamental para a compreensão da base neural do aprendizado perceptual. A pesquisa neurofisiológica tem utilizado primatas nas investigações para abordar os mecanismos neurais subjacentes à aprendizagem perceptual visual. Estudos anteriores demonstraram que a realização de treinamento pode ter efeitos significativos fracos ou nenhuma alteração sobre a sensibilidade dos neurônios em áreas visuais iniciais. Mas as evidências mais recentes indicam que o treinamento pode causar mudanças a longo prazo na forma como os sinais sensoriais são vistos nas fases posteriores. Estes resultados são discutidos no contexto da especificidade da aprendizagem, que tem sido crucial para a interpretação dos mecanismos subjacentes da aprendizagem perceptual (Kumano \& Uka, 2013).

No Brasil, têm sido realizados importantes trabalhos científicos na área de Psicofísica clínica. Muitas áreas da saúde já utilizam recursos da Psicofísica, da Neurologia e da Psiquiatria, entre as quais estão incluídos o diagnóstico e estudo da patofisiologia de doenças neurológicas e psiquiátricas, principalmente na esclerose múltipla, além de outros quadros relacionados (Moura et al, 2008; Vleugels, 2001, citados por Costa, 2010).

Portanto, fica claro, que o psicólogo que estuda os processos psicofisiológicos sensoriais e perceptuais tem que lidar com uma série de variáveis, que incluem o arranjo físico do estímulo, manipulações de uma única dimensão deste estímulo em ambiente controlado, modificações de maneira sistemática na maneira em que o estímulo é apresentado (escolha do método adequado de apresentação do estímulo) e o controle de tendências ou vieses psicológicos que podem distorcer os resultados (Costa, 2010). 


\section{PSICOLOGIA COGNITIVA}

Spinillo e Roazzi (1989) definem o psicólogo cognitivo como aquele que se interessa não só pela forma como as informações externas são extraídas do meio ambiente, mas, especialmente, como elas são conceitualizadas e organizadas internamente para então serem utilizadas de maneira funcional. Além disso, este profissional se importa com os aspectos relativos às elaborações internas, partindo da premissa de que a resposta dada a determinada situação-estímulo sofreu algum tipo de elaboração mental, e que esta elaboração não depende apenas do estimulo externo apresentado, mas dos processos cerebrais internos presentes na mente do indivíduo. Também é destacada pelos autores a importância de compreender que, embora o objeto principal de estudo da Psicologia Cognitiva sejam as funções cognitivas, não é descartada a relação com os processos afetivo-emocionais. Assim, ela é uma das áreas da Psicologia que estuda a cognição (memória, percepção, abstração, atenção, funções executivas, raciocínio, pensamento, além de outros processos mentais subjacentes ao comportamento).

Ellis e Young (1996) definem a Psicologia Cognitiva como o estudo dos processos mentais superiores que tornam possível a capacidade diária de reconhecer objetos familiares e pessoas próximas para a interação com o mundo, falar, ler e escrever, planejar e executar ações, pensar, tomar decisões e evocar informações. De acordo com Castro e Landeira-Fernandez (2010, citados por Fonseca et al., 2011), as questões sobre a cognição e a compreensão da relação mente-corpo têm sido o foco de interesse da humanidade desde a antiguidade. Civilizações anteriores, como as do Egito, Mesopotâmia, Índia e China, buscaram compreender em qual região do corpo a alma poderia ser localizada. No entanto, parece haver vestígios de que o homem pré-histórico já percebia a existência de relações entre traumatismos 
cranianos e alterações cognitivas como perda de consciência, déficits na memória e mudanças no comportamento, pressupondo a possibilidade de haver associação entre a região da cabeça e as funções básicas da vida.

O final da década de 1950 foi considerado o marco da "revolução cognitiva", no qual ideias e conceitos teóricos de diferentes áreas do conhecimento convergiram em uma estrutura que permitiu o início de um movimento intelectual que privilegiou o estudo dos processos mentais. A partir da década de 1960, estabeleceram-se as bases para a gradual substituição do Behaviorismo pela Psicologia Cognitiva como orientação teórica predominante na área (Fonseca et al., 2011).

A Psicologia de Wundt (1879, citado por Vasconcellos \& Oliveira, 2004), poderia ser considerada como antecessora da Psicologia Cognitiva, pois se diferenciava do referencial teórico do Behaviorismo e da Gestalt. Sua proposta era pôr em prática um programa de pesquisa designado para estabelecer a Psicologia como uma ciência natural. Os primeiros fundamentos dados à Psicologia, enquanto disciplina científica diferenciando-se da Filosofia, visavam uma "ciência da vida mental", contrária às ideias de uma "ciência do comportamento". A linha teórica proposta por Wundt tornou-se conhecida como Estruturalismo, descrevendo as ocorrências mentais como tendo implicações estruturais.

O método de investigação utilizado por Wundt foi o Introspeccionismo, visto que defendia o estudo das experiências sensoriais por meio das informações conscientes. Este método funcionamento da mente poderia ser auto-observável (Sternberg, 2010). Em alguns dos estudos para verificar a veracidade da proposta teórica eram apresentados aos sujeitos, sob cuidadosas condições controladas, problemas a serem resolvidos mentalmente, pedindo, em seguida, para dizerem de que maneira eles tinham procedido pelo relato do conteúdo de sua consciência. Porém foi observado que os sujeitos podiam responder corretamente os problemas, mas não conseguiam explicar como chegavam à resposta. O resultado do estudo apontou importantes questões, sendo a primeira delas a de que a introspecção não tem como atingir os processos que não são conscientes. Em segundo lugar, havia a dificuldade de explicar os processos mentais por meio de uma 
descrição verbal homogênea, visto que estavam submetidas a experiências subjetivas e, portanto, diferentes, tornando impossível o relato objetivo dos conteúdos mentais da consciência, que são o próprio objeto de estudo. Portanto, a introspecção não poderia ser considerada uma metodologia adequada para descrever o modelo do funcionamento da mente, pois a multiplicidade da cognição não está acessível à experiência consciente (Schultz \& Schultz, 1994, citado por Vasconcellos \& Oliveira, 2004).

De acordo com Springer \& Deutsch,1998, na década de 1960, Bartlett et al. convenceram a comunidade científica de que o Behaviorismo era uma teoria incompleta. A contribuição dos estudos dos primeiros psicólogos cognitivos e as evidências da Psicologia da Gestalt, da Psicanálise e da Neurologia europeia mostraram que a percepção estrutura o comportamento em si e também postularam que a percepção em si mesma é um processo construtivo, que depende da relação entre o estímulo e a organização mental. Assim sendo, a tarefa principal da Psicologia Cognitiva era a de analisar os processos cerebrais entre o estímulo e o comportamento. Portanto, teve início o grande interesse nos estudos, que permitia a compreensão das funções mentais mais elevadas, tanto no cérebro de indivíduos normais, quanto de doentes ou lesionados.

Embora a mente tenha uma área que os behavioristas não consideravam, eles estavam certos ao enfatizarem a importância de estudar o comportamento de forma objetiva e de considerar que as representações internas não eram evidentes para uma análise objetiva. Porém, nas décadas de 60 e 70, com o desenvolvimento das ciências neurais e com o aprimoramento dos métodos de imagem cerebral, foi possível estudar as representações internas sensoriais e motoras, tanto em animais quanto em humanos (Gazzaniga et al., 2006; Kandel et al., 2000). 


\section{O DESENVOLVIMENTO DA NEUROPSICOLOGIA}

No final do século XIX e início do século $X X$, havia o interesse pela compreensão dos elementos de ordem psicológica por meio de respostas fisiológicas. Eram frequentes as tentativas de encontrar relações estruturais que explicassem as diferentes funções do sistema nervoso, como por exemplo, a preocupação com a ação reflexa, com a natureza da condução nervosa e com a organização estrutural do sistema nervoso, o interesse no estudo de diferentes funções psicológicas em diversas áreas do cérebro e, também, o empenho em descobrir como as informações chegavam até os sentidos e como eram transmitidas ao cérebro. Um importante estudioso do início do século XIX, Gall, propôs a doutrina da "organologia", que depois passou a ser conhecida como "frenologia". A frenologia destacava que o desenvolvimento das habilidades humanas e dos animais poderia estar relacionado às protuberâncias encontradas na calota craniana, ou seja, as áreas maiores poderiam indicar maior desenvolvimento de habilidades relacionadas àquela área. Porém, pesquisas posteriores mostraram que o postulado de Gall não foi confirmado (Springer \& Deutsch, 2008; Wertheimer, 1991).

As pesquisas desenvolvidas por Flourens (1820), nas quais partes do cérebro sofriam remoção cirúrgica, mostraram que o cérebro operava como um todo, mas que certos lobos possuíam funções específicas dentro do conjunto. Em 1861, Broca identificou no cérebro o que ele considerou como o centro da fala. Em um caso clínico de um paciente com lesão encefálica, ele percebeu que o paciente era incapaz de se expressar de modo compreensível, visto que emitia apenas uma palavra para se comunicar (Gazzaniga et al., 2006; Higgins \& George, 2010; Mäder, 1996; Wertheimer, 1991).

Assim, Broca propôs uma nova teoria, embora ainda concordasse com Boulliaud ao considerar que a sede, portanto não o órgão, da linguagem 
articulada estava no lobo frontal. Porém, apesar de ter recebido o mérito por estas descobertas, na literatura são encontradas contribuições de outros estudiosos para tal (Andrade, Santos \& Bueno, 2004).

As concepções de Broca mostraram um ponto considerado básico para o estabelecimento da Neuropsicologia, pois continha duas ideias-chave: 1) a interrupção da linguagem poderia ocorrer independentemente de outros processos cognitivos; 2) a linguagem poderia estar localizada em uma região específica do cérebro. Tal pressuposto levou ao desenvolvimento estudos por décadas, relacionando as lesões e enfermidades em várias regiões do cérebro e as suas possíveis consequências no comportamento (Cagnin, 2010; Springer \& Deutsch, 1998).

Em 1876, Wernicke apresentou um caso que complementava as descobertas de Broca em relação à linguagem. Ele relatou a história de uma vítima de acidente vascular cerebral que podia falar quase normalmente, mas tinha dificuldade na construção de sentenças e suas palavras não faziam sentido para quem ouvia. Além disso, também tinha dificuldade na compreensão tanto da linguagem escrita como da falada (Gazzaniga et al., 2006).

O neurologista Lichtheim (1885, citado por Springer \& Deutsch, 1998), propôs um modelo cerebral do reconhecimento e produção de palavras faladas e escritas a partir dos estudos de pacientes com lesão cerebral, que propunha cinco diferentes "centros" interligados. O tipo de dificuldade apresentada estava relacionado à localização do dano no cérebro. A proposta de Lichtheim obteve notoriedade até o início do século XX, porém os novos estudos nesta área e a observação individual dos pacientes mostraram a inconsistência dos resultados, visto que os dados anatômicos não possibilitavam a localização de modo preciso dos centros responsáveis pelas diferentes funções.

Os fisiologistas Fritsch e Hitzig constataram nova evidência de localização de funções em soldados que sofreram prejuízos cranianos durante a Guerra Franco-Prussiana (1870-1871). Fritsch descobriu a ocorrência de alguns movimentos do olho ou do dedo, quando uma área do cérebro vivo era tocada ao longo da fissura de Roland. Foram realizados por eles vários experimentos com animais com métodos de excitação e extirpação corticais, 
que resultaram no princípio da representação contralateral, isto é, as funções de um determinado lado do corpo são representadas no hemisfério cerebral do lado oposto. Posteriormente, Franz e Lashley consideraram o que Flourens havia postulado antes, tanto no que se refere ao cérebro como um todo quanto na especificidade dos lobos. Mais tarde, os gestaltistas Köhler, Goldstein e Scheerer realizaram estudos que deram maior embasamento aos princípios de equipotencialidade de Lashley, que consistiam na ideia de que partes do cérebro apresentavam potencial para executar as funções de outras partes se estas sofressem danos, e de ação maciça, ou seja, a atuação do cérebro como um todo e de modo integrado, funcionando como uma grande engrenagem. Este princípio ainda é adotado atualmente, embora também seja considerada a existência da especificidade das áreas em níveis variados, em especial no que se refere às experiências sensoriais mais básicas e em relação aos movimentos específicos (Wertheimer, 1991).

De acordo com Lezak (1995), durante a Primeira Guerra Mundial, Goldstein observou que alguns soldados com lesões cerebrais muitas vezes apresentavam dificuldades no pensamento abstrato, memória e planejamento, bem como na execução de tarefas consideradas simples. Durante muitas décadas foram criados vários instrumentos com a finalidade de detectar dificuldades de origem orgânica e de diferenciá-las de outros transtornos psiquiátricos. Grande parte desses instrumentos eram variações dos testes de desempenho não verbais usados para a avaliação da inteligência geral.

$\mathrm{Na}$ década de 1930 um novo enfoque foi proposto na Neuropsicologia, visto que foi questionado o valor dos estudos dos casos únicos, como no do diagrama de Lichtheim (modelo teórico da reprodução da palavra falada e escrita), em 1885, por apresentar problemas metodológicos. Ele partiu de dados qualitativos e não quantitativos, o que dificultava a padronização dos resultados. Foi então sugerido um enfoque de análise grupal, incluindo grupos com indivíduos normais, baseado em informações mais consistentes sobre a localização da lesão cerebral e o desempenho dos grupos em uma série de testes padronizados e quantificáveis. Em 1960 surgiu outra abordagem derivada dos estudos de Geschwind, em que reconsiderou e reconheceu o valor da formação do diagrama e das análises dos casos únicos. O retorno do 
interesse na abordagem dos casos individuais apoiou a Neuropsicologia moderna (Cagnin, 2010; Springer \& Deutsch, 1998).

Kristensen, Almeida e Gomes (2001) em seus estudos de revisão da literatura sobre o desenvolvimento Histórico e Fundamentos Metodológicos da Neuropsicologia Cognitiva constataram que este termo foi utilizado pela primeira vez em 1913 em uma conferência proferida por Osler, nos Estados Unidos. Também foi usado como um subtítulo na obra de 1949 de Donald Hebb, chamada The Organization of Behavior: A Neuropsychological Theory.

Com o desenvolvimento das técnicas de neuroimagem muitas evidências das relações físicas entre a mente e o cérebro puderam ser confirmadas e outras novas descobertas sobre as possibilidades de relação entre o cérebro e o comportamento foram obtidas. O localizacionismo, foi substituído por um novo conceito de função amplamente investigado por vários estudiosos. O axioma proposto por Luria (1973,1980, citado por Freitas, 2006) sugeriu que deveria ser discriminada a denominação da palavra função cerebral quanto ao seu significado, sendo um deles relativo ao tecido nervoso e, o outro, ao sistema funcional mais complexo (funções cognitivas superiores) encarregado de receber, processar e armazenar as informações, que chegam do mundo externo e interno, regulando e verificando as estratégias comportamentais e a própria atividade mental.

Além disso, pesquisas sobre a lateralização hemisférica também levaram a muitos questionamentos e contribuições, como, por exemplo, o estudo de Joseph (1988) em que foram avaliadas duas pessoas submetidas à remoção completa do corpo caloso. A partir de investigações clínicas, neurocomportamentais controladas e do uso de testes neuropsicológicos, pôde ser observado que, embora os dois casos tenham apresentado as síndromes de desconexão exclusivas para pacientes com "cérebro dividido", eles também diferiam claramente. O hemisfério esquerdo do caso 1 desenvolveu o controle motor bilateral, ao passo que o caso 2 mostrou duas formas independentes de "consciência" para cada um dos hemisférios, uma no direito e a outra no esquerdo. Por exemplo, o hemisfério direito do caso 2 foi capaz de reunir, compreender, recordar e expressar várias formas de informação (não-verbal), bem como agir de modo independente, manifestando o comportamento no lado 
esquerdo do seu corpo. Na verdade, o braço e a perna esquerda do caso 2 não só controlavam o movimento de modo intencional como, às vezes, realizavam atividades que seu hemisfério esquerdo considerava censurável e irritante. Em alguns casos, foram observadas lutas físicas que envolviam os dois lados do corpo do paciente (esquerdo e direito). Por outro lado, o hemisfério direito do caso 1 parecia apresentar as funções cognitivas superiores em nível mais rebaixado.

Com todos estes achados, a Neuropsicologia se estruturou como uma área de grande importância e que, juntamente com o avanço tecnológico do imageamento cerebral e outros ramos das Neurociências, pôde trazer muitas respostas que até então eram meras especulações filosóficas.

\subsection{NEUROPSICOLOGIA CLÍNICA}

Atualmente, a Neuropsicologia é um campo do saber aplicado e relacionado a diversos ramos do conhecimento científico. Tem como objetivo estudar a disfunção cerebral, desde o nascimento até o final da vida. Estabelece as associações existentes entre o funcionamento do cérebro no que se refere aos mecanismos fisiológicos, às funções cognitivas e emocionais e como estes se expressam por meio do comportamento em condições normais e patológicas. É aplicada tanto no contexto científico quanto clínico, utilizando como teoria básica os conhecimentos da Psicologia Cognitiva e das Neurociências (Andrade, Santos \& Bueno, 2004; Malloy-Diniz et al, 2010; Miotto, 2007; Lefèvre, 1998).

Rao (1996) diferencia a Neuropsicologia Humana e a Neuropsicologia Clínica, considerando a primeira como multidisciplinar, com especialistas da Psicologia Experimental e Cognitiva, da Neurologia, da Psiquiatria, da Linguística, da Fonoaudiologia e das Neurociências em geral. Já a Neuropsicologia Clínica é uma área exclusiva do psicólogo clínico, que é encarregado da aplicação do conhecimento científico derivado de pesquisas para a investigação diagnóstica e tratamento dos indivíduos com suspeita de danos cerebrais. Vendrell (1998, citado por Capovilla, 2005), afirma que os 
termos Neuropsicologia Cognitiva e Neurociência Cognitiva têm sido usados por vários autores como referência à mesma área de estudo.

De acordo com Sbordone, Saul e Purisch (2007), a Neuropsicologia no contexto clínico é uma ciência aplicada que diz respeito à relação entre o cérebro e o comportamento. Ela integra os campos da Psicologia Clínica e da Neurologia Comportamental que utilizam testes psicológicos especializados, desenvolvidos para avaliar uma ampla variedade de domínios comportamentais, cognitivos e emocionais que são dependentes da integridade estrutural e funcional do cérebro. Podem ser úteis para avaliar indivíduos com suspeita de disfunção cerebral focal ou difusa, pela identificação dos problemas comportamentais, cognitivos e emocionais que necessitam de tratamento psicológico e de reabilitação cognitiva. Também possibilitam o acesso às dificuldades e potencialidades do paciente por meio dos testes, baseando-se em informações das anamneses e entrevistas específicas sobre outras áreas significativas, por exemplo, a acadêmica, a profissional, história médica e registros psiquiátricos para determinar o nível pré-mórbido do funcionamento do paciente. Com estas informações, o neuropsicólogo tenta determinar como o funcionamento comportamental, cognitivo, social e emocional do indivíduo pode ter sido alterado por um prejuízo cerebral, particularmente quanto à capacidade do indivíduo para detectar e monitorar sinais ambientais e estímulos, reconhecer os seus déficits comportamentais e cognitivos, comunicar-se de forma eficaz com os outros, aprender e reter informações, realizar atividades domésticas (cozinhar, lavar, etc.) e na comunidade, exercer um juízo crítico e responsável, manter relacionamentos com os demais, fazer novos amigos, interagir em situações sociais ou de trabalho, na manutenção do emprego, conseguir acompanhar a vida acadêmica e profissional de modo satisfatório.

Estuda como determinadas estruturas e processos cerebrais medeiam o comportamento e abrange aspectos que vão desde motivações a emoções, bem como os cognitivos. Como o próprio nome sugere, a Neuropsicologia Cognitiva representa uma convergência entre as áreas da Psicologia Cognitiva e da Neuropsicologia. Campbell (1987, citado por Eliis \& Yong, 1996) concluiu que 
A Neuropsicologia é cognitiva na medida em que se propõe a elucidar os mecanismos das funções cognitivas envolvidas, tais como: o raciocínio, a leitura, a escrita, a fala, o reconhecimento ou a evocação, com base nas evidências da neuropatologia (p.4)

A Neuropsicologia Cognitiva tem, então, como objetivos básicos explicar os padrões prejudicados ou intactos do desempenho cognitivo, observados em pacientes com lesões cerebrais em termos de danos a uma ou mais áreas cerebrais, baseando-se no modelo ou na teoria do funcionamento cognitivo normal. Deste modo, a prosopagnosia e a anomia observadas em alguns pacientes poderiam ser explicadas por danos a um ou mais dos processos necessários para efetuar a produção normal de voz e do reconhecimento de face, respectivamente (Ellis \& Young, 1996).

Segundo Malloy-Diniz et al. (2010), para alguns autores a avaliação neuropsicológica compreende um campo de estudos e prática mais atual em relação à avaliação psicológica clássica (psicométrica). Pode-se afirmar que são análogas quanto à medida de variáveis psicológicas e distintas basicamente no que concerne aos objetivos e contextos clínicos, particularmente no que diz respeito à identificação das bases neurológicas relacionadas ao comportamento avaliado. Um outro fator que as diferencia se refere à análise dos resultados. Por exemplo, na psicometria as tarefas são propostas para medir uma determinada aptidão ou a personalidade em um teste específico. Na bateria neuropsicológica, diversos testes e tarefas são integrados com o propósito de interpretação das relações entre as funções psicológicas e o substrato neural.

Quanto a definição do profissional neuropsicólogo, Lefèvre (1989) afirmou que a avaliação neuropsicológica é uma prática inerente à atividade do psicólogo e que, para tal exercício, deverá o profissional aprofundar os seus conhecimentos sobre a relação funcional entre o cérebro e a cognição. Para Sbordone, Saul e Purisch (2007) é um profissional com formação em Psicologia e conhecimentos profundos tanto teóricos quanto práticos que aplica os princípios de avaliação e intervenção com base no estudo científico do comportamento humano em relação ao funcionamento normal e anormal do 
sistema nervoso central. Presta serviços de diagnóstico e de tratamento e demonstra competência na aplicação de tais princípios.

Conforme Santos (2005), a Neuropsicologia brasileira despontou nos anos 50, tendo como um dos pioneiros o médico Antônio Frederico Branco Lefèvre (1916-1981), autor do primeiro tratado brasileiro de Neurologia infantil e organizador do Exame Neurológico Evolutivo (ENE) em 1972, cujas atividades, como pesquisador e docente, nortearam os primeiros estudos de funções cognitivas em crianças. Nos anos 80, a psicóloga Beatriz Lefèvre (1989) publicou o livro Neuropsicologia Infantil em que mostrou a importância e o perfil da avaliação neuropsicológica em diversas patologias. Além disso, foi publicada a Resolução $n^{\circ}$ 002/ 2004, do Conselho Federal de Psicologia, que regulamentou a prática da Neuropsicologia no Brasil para o diagnóstico, acompanhamento, tratamento e pesquisa das funções cognitivas, das emoções e do comportamento como especialidade em Psicologia.

A Neuropsicologia Clínica foi oficialmente reconhecida em 1996 como a área de especialidade do psicólogo pela APA. Essa instituição, o CFP e o CRP entendem que são funções do neuropsicólogo avaliar e indicar tratamentos para os efeitos psicológicos de um dano cerebral. Para tanto, esse profissional deverá fazer uso de uma metodologia de trabalho que inclui a avaliação neuropsicológica (Thiers, Argimon \& Nascimento, 2005).

\subsubsection{CONTRIBUIÇÃO DAS TÉCNICAS DE IMAGEM CEREBRAL PARA A NEUROPSICOLOGIA}

De acordo com Gazzaniga et al. (2006), grande parte dos estudos iniciais sobre a imagem do cérebro foram feitos na Itália. O fisiologista Angelo Mosso estudou pacientes com defeitos no crânio e notou que a pulsação do córtex humano aumentava em determinadas regiões durante a atividade mental, assim, por meio desta observação estabeleceu a relação entre o fluxo sanguíneo cerebral e a atividade neural do cérebro. Porém, foi somente após a Segunda Guerra Mundial que os estudos sobre a relação entre o fluxo sanguíneo cerebral e a função neural começaram a ser quantificados. 
Os primeiros trabalhos na área sobre medida do fluxo sanguíneo cerebral foram realizados com animais. Kety e Sokoloff foram os primeiros a iniciar pesquisas a este respeito, contribuindo para o surgimento dos primeiros aparelhos de imagem cerebral. Ingvar e Lassen desenvolveram um capacete com contadores de cintilação, que cobria toda a cabeça e media as mudanças regionais no fluxo sanguíneo cerebral durante uma atividade mental. Mais tarde foi desenvolvida uma técnica mais sofisticada conhecida por tomografia por emissão de pósitrons (TEP).

Posner e Petersen foram os primeiros que usaram a TEP, cuja função é medir as mudanças de fluxo sanguíneo no cérebro por meio do uso de radioisótopos injetados na corrente sanguínea. Os indivíduos que estão sendo investigados por meio desta técnica são submetidos a uma tarefa cognitiva com o objetivo de rastrear as possíveis mudanças regionais do fluxo sanguíneo no cérebro durante a execução da tarefa. Outro avanço em relação a este aspecto foi o desenvolvimento da imagem por ressonância magnética (RMF), não invasiva e que não utiliza substâncias radioativas, além disso, as tarefas cognitivas aplicadas podem ser contínuas e não precisam se restringir aos 60 segundos, como no caso do uso da TEP, pelo fato das substâncias radioativas estarem agindo no cérebro (Ducan, 1997; D’Espósito, 2000; Meyer, 1989; Petersen \& Fiez, 1993).

Ferreira (2006) por meio de técnicas de neuroimagem encontrou diferenças de metabolismo cerebral e alterações estruturais em alguns pacientes com esquizofrenia quando comparados aos controles. Nos últimos anos esta técnica auxiliou na expansão do estudo da função cerebral em atividade realizada por indivíduos normais, porque registra dados com uma resolução temporal de vários segundos, permitindo escanear a ativação durante qualquer tarefa e fornece as mudanças decorrentes na atividade cerebral. Porém esta técnica pode ser afetada por qualquer movimento do indivíduo, anulando os resultados nestes casos. Estudos recentes de Bennett, Shaywitz et. al. com o uso da RMF para medir as mudanças no fluxo sanguíneo demonstraram padrões diferenciais de atividades nos cérebros de homens e mulheres durante uma tarefa cognitiva (Springer \& Deutsch, 2008).

Segundo Martin (2013), as pesquisas em seres humanos com as 
técnicas de neuroimagem e observação de alterações comportamentais específicas associadas a lesões corticais características possibilitam conhecimento das funções de grande parte das divisões citoarquitetônicas identificadas por Broadmann.

Algumas pesquisas mostraram que as alterações neuropsicológicas devido ao estresse emocional vivido por crianças foram detectadas em exames de neuroimagem. Na revisão da literatura de Oliveira, Scivoletto e Cunha (2010) foram encontrados 607 artigos sobre o tema, dos quais 19 foram selecionados para análise. Embora não houvesse concordância nos postulados, foram encontradas evidências de que grupos com experiência de estresse emocional precoce (EEP) apresentaram prejuízos em funções neurocognitivas como atenção, inteligência, linguagem, tomada de decisões e funções executivas, e mostraram alterações no hipocampo, no corpo caloso, córtex pré-frontal e córtex cingulado anterior. Além disso, também ocorrem transtornos psiquiátricos e alterações comportamentais nestes casos. 


\section{PERCEPÇÃO VISUAL}

A percepção pode ser definida como um sistema integrativo de sensações e conceitos sobre os objetos e a sua utilização no espaço e no tempo. Duas questões gerais fazem parte dos mecanismos perceptivos, sendo uma delas, a identificação do objeto (suas propriedades físicas, função e nomeação) e a outra, a localização (relação espacial). Tais atributos cognitivos são necessários para a sobrevivência. Embora o reconhecimento visual e a localização não atuem de modo totalmente independente, há consenso de que são tarefas qualitativamente diferentes e que são realizadas por diferentes regiões do cérebro. O reconhecimento de objetos depende da área cortical de recepção para a visão (área primária) e da região denominada via ventral ou ociptotemporal. A localização é realizada pela via dorsal ou ociptoparietal. Portanto, se há prejuízo na região de reconhecimento do sistema visual podese ainda perceber relações espaciais entre os objetos, contudo, não é possível discriminar os objetos entre si (como por exemplo, um cubo de um cilindro). $\mathrm{O}$ inverso também pode ocorrer, isto é, pode haver o reconhecimento do objeto, mas não a identificação da sua localização (Atkinson, et. al., 1995; Fluentes, Andrade, Diniz, Baise \& Camargo, 2012, Martin, 2013).

Forgus (1971) descreveu a percepção como um processo de extração de informação influenciado pela aprendizagem e a considerou o âmago da cognição, quando compreendida de modo amplo, em relação à natureza da recepção, aquisição, assimilação e utilização do conhecimento. Com isso, concebeu a percepção como o "superconjunto" e a aprendizagem e o pensamento, como subconjuntos, que auxiliam a extração da informação. Assim, na medida em que o animal vai se desenvolvendo na escala filogenética, a percepção vai sendo cada vez mais enriquecida. Nos mamíferos 
superiores, em especial no ser humano, os processos perceptivos de adaptação foram altamente aperfeiçoados, indicando que os seus programas perceptivos já estariam estabelecidos ou pré-estabelecidos geneticamente.

O objetivo de Forgus era mostrar que, quanto maiores fossem as dificuldades das tarefas ou os estágios do desenvolvimento envolvidos, maior seria a capacidade de extração de informações. Definiu a percepção, a aprendizagem e o pensamento como processos cognitivos que atuam em conjunto, entretanto diferenciados da seguinte maneira: a percepção é o processo cognitivo responsável pela organização da informação do ambiente e a aprendizagem o processo pelo qual a informação é adquirida e armazenada. E por fim, o pensamento é o mais complexo dos processos, que ocorre, quando o organismo está ocupado em resolver problemas e para isso se baseia em modelos ou construção de conceitos.

De acordo com Gregory (1979), os estudos sobre a percepção humana trouxeram muitas discussões sobre as habilidades perceptivas em bebês humanos, contudo o campo de pesquisa nesta modalidade ainda é obscuro em muitos aspectos. Conforme alguns trabalhos citados por ele a seguir:

James (1842), por exemplo, postulava que a percepção dos bebês se configurava como uma "confusão florescente e murmurante". Pesquisas inspiradas em alguns pressupostos filosóficos foram realizadas com adultos, que foram cegos durante toda a sua vida e que posteriormente obtiveram a visão por meio de processo cirúrgico. Essas pesquisas buscavam compreender os processos envolvidos no desenvolvimento da percepção visual, mas surgiram questões de difícil elucidação, porque a noção de percepção estava relacionada às experiências anteriores vivenciadas pelos indivíduos e que, portanto, não poderiam explicar do mesmo modo a ocorrência dos processos de desenvolvimento da percepção visual em bebês humanos. Os estudos sobre a percepção visual envolvendo bebês foram realizados, então, por meio da observação dos seus movimentos oculares, já que ainda não possuíam coordenação motora e linguagem desenvolvida. A coordenação dos movimentos oculares é desenvolvida logo após o nascimento do bebê. $O$ estudo de Fantz mostrou que os bebês buscam fixar mais a visão em figuras que representem um rosto humano do que em desenhos que não apresentem 
as mesmas características da forma estruturada do rosto. Essa amostra do comportamento perceptivo de bebês leva a suposições sobre o reconhecimento inato de rostos, porém, também não é descartada a hipótese de que exista uma aprendizagem precoce por parte dos bebês em relação aos rostos de suas mães. Outro dado importante é que os bebês parecem apresentar preferência por objetos sólidos em comparação à representação plana destes mesmos objetos, levando à hipótese de que exista alguma avaliação inata de profundidade.

Bruner observou que os bebês ajustavam a abertura de suas mãos de acordo com o tamanho dos objetos, ou seja, pareciam usar a visão para avaliar o tamanho, a direção e a distância dos objetos. Além disso, obteve amostras de comportamento indicando que os bebês possuíam expectativas em relação aos objetos com base nos dados recebidos visualmente. Também foram encontrados indícios de conhecimento de propriedades não visuais de objetos como tamanho e distância, mas não de reconhecimento inato de objetos específicos. A percepção olfativa parece auxiliar os bebês no reconhecimento do seio materno, assim como os cheiros novos ou significativos parecem atrair a atenção dos bebês.

Desde o período neonatal é observado o início de comportamentos que requerem a mediação aferência-eferência do Sistema Nervoso Central (SNC). O recém-nascido tem a mesma forma de integração de experiências sensoriais que os adultos, para as diferentes modalidades sensoriais. No lactente, é a atenção visual que desperta o interesse e a motivação para, em primeiro momento, explorar o mundo exterior com os olhos e, posteriormente, explorá-lo com as mãos. Contudo, todos os órgãos dos sentidos estão envolvidos neste processo, mas, é a visão o primeiro sistema a permitir ao lactente o contato com o seu entorno, levando-o a fazer rápida síntese da experiência obtida por meio do sistema sensorial (Gagliardo, 2006).

Os estudos de Oliveira (2007) com bebês mostraram que não ocorreram diferenças estatísticas significativas nas funções visuais avaliadas em prematuros e em nascidos a termo, e que nem a experiência visual, nem o tempo de gestação afetam o desenvolvimento da visão espacial em humanos. 
O bebê ao nascer não possui uma acuidade visual muito precisa, assim, somente pode perceber os estímulos visuais maiores, porém no primeiro ano de vida ocorre um rápido desenvolvimento nesta área. Para avaliar, se no bebê o desenvolvimento da acuidade visual está ocorrendo dentro da normalidade, foram desenvolvidos instrumentos específicos que permitem medir quantitativamente a visão de bebês e de crianças. Dessa forma, o desenvolvimento da acuidade visual durante o primeiro semestre de vida pode ser avaliado por vários tipos de técnicas, como exemplo, o olhar preferencial, o nistagmo optocinético e o potencial visual evocado (Atkinsons \& Braddick, 1983; Costa, Oliveira, Bergamasco \& Ventura, 2006; Fielder \& Moseley, 1988; Monteiro \& Roizenblatt, 2010, Oliveira, Costa \& Ventura, 2007).

Os exames e as observações auxiliam na avaliação dos elementos corticais, do tronco encefálico, dos periféricos, da via óptica e do sistema oculomotor. Durante a anamnese verifica-se a existência de queixa relacionada à ocorrência de alteração na função visual, nos movimentos oculares, desvio dos olhos ou movimentos anormais. Deve ser realizado um levantamento de todo o histórico pré-natal, sobre o uso de medicações e a ocorrência de infecções durante a gestação, uso de álcool, tabaco e drogas psicoativas. O período da gestação também é importante, ou seja, é verificado o tempo de ocorrência da gestação, se foi a termo ou prematuro, o peso e as eventuais complicações, como anoxia (falta de oxigênio no cérebro) no período perinatal, tipo de incubadora (aberta ou fechada), em suma, todas, as circunstâncias são investigadas. Estas são de extrema importância, pois as complicações respiratórias graves podem levar a lesões hipóxicas (causadas pelo baixo teor de oxigênio no cérebro). Além disso, devem ser pesquisados alguns hábitos da criança, que podem indicar deficiência visual como, por exemplo, crianças que olham fixamente para luzes fortes, comprimem os globos oculares ou movem as mãos em frente aos olhos. Nas distrofias de cones, em que há perda progressiva da visão central e discriminação de cores prejudicada, as crianças têm fotofobia (aversão à luz). A baixa visão da criança poderá levá-la a não sorrir ou a demonstrar desinteresse pelo ambiente e, ao brincar, poderá levar o brinquedo muito próximo dos olhos, assim como, não demonstrar interesse 
pela televisão ou se aproximar demasiadamente dela (Monteiro \& Roizenblat, 2010).

\subsection{TEORIAS RECENTES DA PERCEPÇÃO VISUAL}

Mais recentemente, duas importantes teorias da percepção foram propostas com base nas representações visuais invariáveis. Uma delas foi apresentada por Marr em 1982 (Gazzaniga et al., 2006 e Lent, 2005). O pressuposto fundamental para o reconhecimento dos objetos foi 0 estabelecimento dos eixos maior e menor, inerentes ao objeto. Tais propriedades geralmente se conservarão ao longo de diferentes pontos de observação. O princípio do processo perceptual seria um "esboço primitivo", baseado nas diferenças de intensidade e cor no mapa retiniano, que produziriam bordas contrastantes capazes de estimular as células da retina de modo diferenciado. Na segunda fase seria elaborado um esboço das relações espaciais (distância entre as bordas e das texturas existentes nos intervalos) ao qual denominou "esboço" 2 1/2D" (que indica a existência da percepção de profundidade, ainda incompleta por não ter sido associada aos outros ângulos de visão do mesmo objeto, ou seja, a outros $2^{1 / 2} \mathrm{D}$ ). A partir destes processos surgiria uma imagem mental provisória do objeto, que pode ainda não ser reconhecido, mas possibilita a orientação no espaço em relação a ele. Por fim, seria criado um "modelo 3D", que reuniria todos os esboços $2^{1 / 2} \mathrm{D}$ do mesmo objeto, armazenados na memória, com a finalidade de detectar seus eixos internos criando uma imagem invariante. Também estariam incluídas as partes "ocultas" do objeto e, uma vez armazenado na memória, o modelo 3D poderia ser recuperado para posterior reconhecimento.

Além disso, dependendo do objeto, se este fosse visto frontalmente o eixo menor poderia produzir uma imagem retiniana maior do que a do eixo maior, que se estaria encurtado. Entretanto, este caso seria considerado particular e se constitui em um desafio para os sistemas habituais de reconhecimento. Portanto, esta abordagem mostra que o reconhecimento não é dado somente pela análise da informação do estímulo, como sugerido por algumas teorias do reconhecimento do objeto. Ao contrário, a definição das 
propriedades básicas é estabelecida pela entrada sensorial e, sequencialmente às outras propriedades do objeto são definidas em relação a essas propriedades básicas.

TEORIA DE MARR (1982)

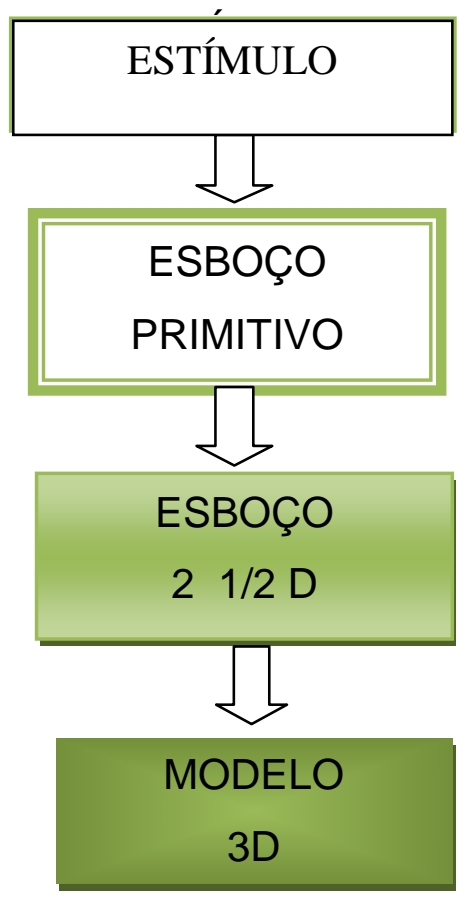

Figura 1. Imagem (estímulo) $\Rightarrow$ Esboço primitivo (bordas contrastantes) $\Rightarrow$ Esboços $2^{1 / 2} \mathrm{D}$ (distâncias entre as bordas e texturas existentes nos intervalos, percepção de profundidade) $\Rightarrow$ Modelo 3D (junção de todos os esboços $2^{1 / 2} \mathrm{D}$ existentes na memória, criação da imagem invariante). Fonte:Lent (2005).

Outra proposta foi desenvolvida por Bierderman (1987), que também conceituou o reconhecimento dos objetos como dado pela análise da parte em relação ao todo. Porém, foi mais além ao explicar o axioma do esboço primitivo, sugerido anteriormente por Marr, pois considerou que as partes componentes dos objetos seriam detectadas pela disposição de suas bordas 
de contraste formando relações espaciais típicas. Assim como, em vez de múltiplos esboços "21/2 D" para cada objeto, o sistema visual seria capaz de identificar unidades perceptuais. Desse modo, qualquer objeto poderia ser descrito como uma configuração de partes limitadas, formando um conjunto de volumes geométricos simples, aprendidos na infância, denominado "geons" que, quando fossem agrupados, poderiam dar a forma aos variados tipos de objetos. Os níveis superiores de codificação da forma seriam mais sensíveis aos aspectos de maior saliência do estímulo. A informação sensorial captada seria variável, dependendo da posição em que fosse vista, porém alguns estímulos não variáveis, como um círculo, por exemplo, poderiam ser vistos em qualquer posição e seria reconhecido sempre como um círculo. A combinação dos geons caracterizando cada objeto seria armazenada na memória na primeira exposição para posterior utilização. Foram identificados cerca de 24 geons e foi calculado que mais de cinco mil objetos poderiam ser especificados por dois geons, e cerca de 140 mil objetos poderiam ser especificados por três geons. Os 24 geons combinados teriam uma capacidade perceptual imensa.

Assim, o reconhecimento perceptual dos objetos é concebido para ser um processo no qual a imagem de entrada é segmentada por regiões de concavidade profunda em um arranjo de componentes geométricos simples, tais como blocos, cilindros, cunhas e cones. O pressuposto fundamental dessa teoria é o reconhecimento por componentes (RBC - "Recognitions-byComponents"), que é um conjunto de componentes (unidades perceptuais) existentes nos objetos, pode ser derivado dos contrastes de cinco propriedades facilmente detectáveis de bordas em uma imagem bidimensional: 1) curvatura; 2) colinearidade; 3) simetria; 4) paralelismo; e 5) junção. A detecção dessas propriedades, geralmente invariante sobre a posição da visualização e da qualidade da imagem permite a precisão na percepção do objeto mesmo quando a imagem é projetada a partir de um novo ponto de vista ou é distorcida. Portanto, o reconhecimento por componentes fornece princípios a serem considerados sobre a relação, até então obscura, entre os princípios clássicos de organização e o padrão de reconhecimento perceptual. As limitações quanto à regularização (pregnância) não caracterizam o objeto inteiro, mas sim os seus componentes. O poder representacional deriva de 
uma combinação irrestrita de geons. O princípio da recuperação componencial pode explicar os principais fenômenos de reconhecimento de objetos. Se um arranjo de dois ou de três geons podem ser recuperados a partir da entrada, os objetos podem ser rapidamente reconhecidos, mesmo quando são novos, tenham uma de suas partes ocultas, estejam girados em profundidade ou quando são apresentados muito distorcidos.

\section{TEORIA DE BIEDERMAN (1987)}

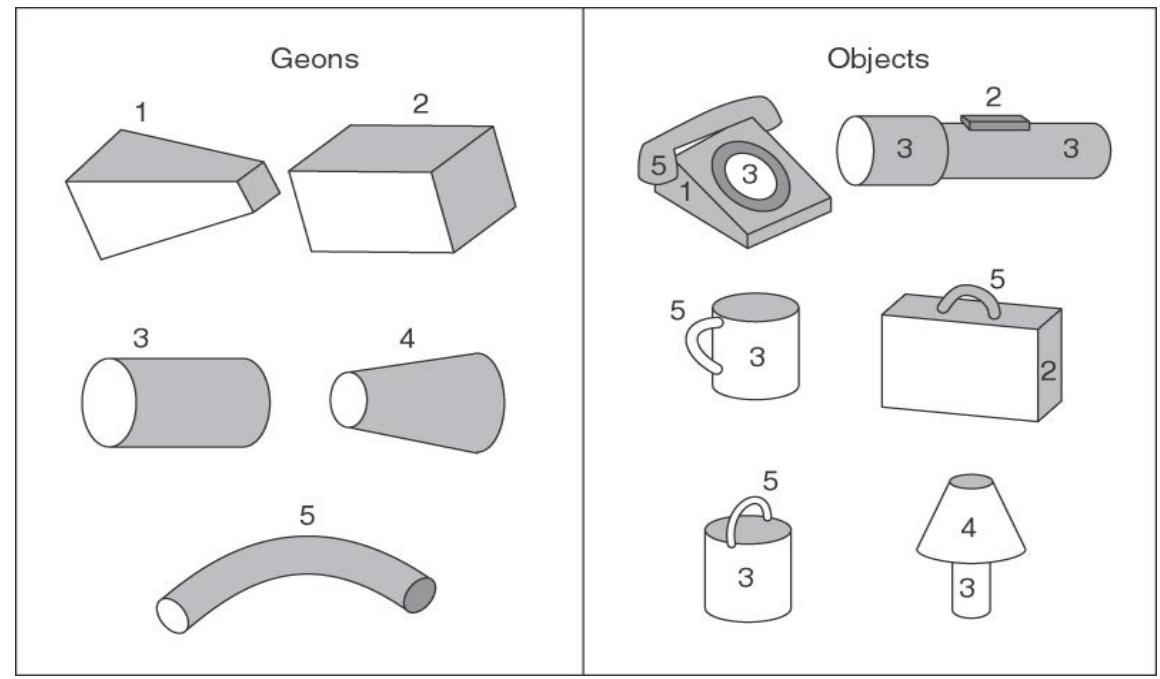

Figura 2. Conjunto de componentes (unidades perceptuais) existentes nos objetos, chamados "Geons". Fonte: Biederman - "Recognition by Components"(sem data de publicação). Recuperado em 20/01/2015, de https://www1.appstate.edu/ kms/classes/psy3215/ObjectRecognition/Geon.htm

Em suma, as teorias de Marr e de Bierderman são centradas no objeto e atribuem a ele eixos invariantes ou típicas associações de bordas, que, armazenadas na memória, serviriam para o reconhecimento posterior. O ponto frágil das duas teorias é o de tratar o sistema nervoso como um computador, programado para realizar certas operações que resultariam em percepção. Os estudos mais recentes, ainda que também fundamentados em preceitos computacionais, porém centrados no indivíduo, consideram a capacidade de aprendizagem tanto do cérebro como da última geração de computadores adaptativos. Eles explicam que na primeira vez que se vê um objeto são armazenadas na memória algumas imagens bidimensionais do mesmo. $O$ reconhecimento do objeto em outras ocasiões é dado por imagens 
subsequentes, minimamente diferentes das anteriores, que seriam comparadas a elas. Portanto, se fossem parecidas, o objeto seria reconhecido como o mesmo anterior. Em situação oposta, seria identificado como um novo objeto. Além disso, à medida que aumentasse a quantidade de imagens semelhantes, haveria maior chance de acerto e a precisão do reconhecimento também seria maior. Estas teorias buscam responder duas questões essenciais da percepção: a discriminação de um objeto em relação aos demais e ao fundo (relação figura e fundo) e a constância perceptual. São consideradas a ocorrência da sequenciação lógica do simples ao complexo e o envolvimento de etapas analíticas, seguidas de mecanismos sintéticos de "reconstrução mental".

Porém, Perrett et al. (1994, citado por Gazzaniga et al., 2006, p. 224) afirmam que ainda há controvérsias nas teorias dependentes da visão sobre a dinâmica dos processos perceptivos relacionados ao reconhecimento do objeto no que se refere à definição do sistema de coordenadas em que este ocorre. Essas postulam que a percepção depende do reconhecimento do objeto a partir de um determinado ponto de vista e a percepção se origina da análise da informação a partir de um ponto de vista. Propõem que existe uma gama de representações específicas na memória, portanto apenas é necessário combinar um estímulo com uma representação armazenada. O princípio básico é que esta representação considera o objeto a partir de uma determinada posição espacial, que difere de outra, referente ao objeto em outra posição (exemplo, lateral ou frontal). Deste modo, supõe que a habilidade para o reconhecimento dos estímulos (imagens em posições espaciais diferentes) representando o mesmo objeto ocorra em um estágio posterior do processamento.

Tarr et al. (1997, citados por Gazzaniga et al., 2006, p. 225) também alertam para uma deficiência das teorias dependentes da visão, que colocam grande importância na memória visual para a percepção, pois elas a consideram como elemento central para o reconhecimento do objeto a partir de um determinado ponto de vista (posição). Assim, cada objeto exigiria representações multifacetadas na memória, cada uma delas associadas a um ponto de observação diferente. Por isso, é evidente que as teorias não levam 
em conta a complexidade dos processos envolvidos, supondo que os processos de reconhecimento são capazes de combinar a informação com as representações armazenadas, por meio de sistemas de interpolação.

Por outro lado, estudos recentes comprovam que o reconhecimento de um objeto, a partir de uma nova perspectiva, ocorra em decorrência de diversos fatores, ou seja, pela comparação da informação do estímulo com as representações armazenadas e pela escolha da melhor combinação. Essa suposição é embasada por experimentos com novos objetos, portanto, esta abordagem minimiza a contribuição da experiência anterior (memória) e a possibilidade de estratégias verbais. O tempo necessário para decidir, se dois objetos são iguais ou diferentes, aumenta à medida que os pontos de vista se diferenciam, mesmo quando cada membro do conjunto de objetos contenha uma característica exclusiva (Gazzaniga et al., 2006; Milner \& Goodale, 1995; Riddoch \& Humphreys, 2001).

Segundo Lent (2005), os sistemas sensoriais se encarregam das primeiras etapas da percepção, tornando-se responsáveis pela sua fase analítica. É como se os alvos da percepção fossem minuciosamente dissecados em suas partes constituintes e suas propriedades (cores, tons, cheiros, etc.); no entanto, ao findar o processo, não há consciência da soma de partes e propriedades, mas sim dos objetos como percepções globais. Tal fenômeno perceptivo conduz à hipótese de que, além dos mecanismos analíticos, devam existir outros de natureza sintética, capazes de reunir as partes e propriedades em um conjunto único que faça sentido. Os mecanismos analíticos e sintéticos são partes integrantes da percepção. A transição dos primeiros para os segundos é gradual e na interface há uma grande área de superposição.

De modo geral as teorias do reconhecimento do objeto, tanto as dependentes quanto as independentes da visão, consideram a decomposição de um cenário ou do objeto em suas partes componentes. Podendo envolver representações hierárquicas, em que cada etapa sucessiva acrescenta mais complexidade. As linhas, por exemplo, podem ser combinadas em arestas, ângulos e interseções para a análise de um conjunto visual em suas regiões componentes. Estas, por sua vez são agrupadas em partes, que depois serão 
organizadas em objetos diversos. Assim sendo, o reconhecimento de um triângulo, exigiria a capacidade de perceber os três segmentos, que se unem, formando três ângulos em fechamento. Porém, também seria possível perceber outras formas, se estes mesmos segmentos fossem organizados de modo diferente. A hipótese central é de que a informação visual é distribuída por diferentes processos, o analítico, em que os processos são inicialmente destinados a analisar os atributos de um estímulo, e outros processos referentes à forma, à cor e à informação sobre a dinâmica ou o movimento da imagem visual. Por fim, a percepção dos objetos inteiros é obtida em etapas, que definem cada característica do objeto (Gazzaniga et al., 2006).

\subsection{DIFERENÇAS ENTRE PERCEPTOS E IMAGENS}

A percepção é compreendida na Psicologia Cognitiva e nas Neurociências como a função cerebral responsável pela atribuição de significados aos estímulos sensoriais, que ocorre por intermédio dos processos fisiológicos e cognitivos, que podem ser divididos em: entrada ou aquisição da informação, interpretação, seleção e organização das informações (Atkinson et al., 1995; Gazzaniga et al., 2006; Lent, 2005).

A imagem geralmente é menos intensa e experimentada de forma menos clara do que a percepção do objeto real. A intensidade da percepção permite verificar a diferença entre alguma coisa que se "imagina" e alguma coisa que se vê ou ouve na realidade. Porém varia entre as pessoas e em um mesmo indivíduo. Humphrey (1948, citado por Krech \& Crutchfield, 1980), relatou o caso de um homem que realizava somas com o auxílio de uma régua imaginária de cálculo, colocando-a de uma forma determinada, fazia a leitura mentalmente. Normalmente, não via toda a régua, mas apenas a parte que estava sendo utilizada. Estas imagens muito minuciosas foram chamadas de "eidéticas" em 1907.

Segundo Krech e Crutchfield (1980), foi sugerido que a diferença entre a imagem e a percepção poderia estar na "fluidez", ou seja, a percepção de um objeto real é, em grande parte, determinada pelas propriedades estimuladoras do objeto; já as imagens são mais fluidas. Às vezes, uma imagem visual pode 
ser deslocada voluntariamente para vários lugares, organizando-se como um conjunto ou até mesmo como outros tipos de objetos. Pode ser "vista" em objetos opacos, em tamanhos equivalentes a duas vezes o seu tamanho original, deformada ou em cor variável.

Contudo, nem sempre se pode saber se a experiência é apenas interior (proveniente de uma imagem) ou originária de um objeto real. As diferenças são apresentadas como guias importantes, mas as investigações experimentais não são conclusivas quanto à existência de uma fronteira nítida entre as qualidades da percepção de um objeto real e de uma imagem.

Damásio (2000) se refere ao termo imagens como padrões mentais com uma estrutura construída com os sinais provenientes de cada uma das modalidades sensoriais (visual, auditiva, olfativa, gustativa, e sômato-sensitiva). Assim, a palavra imagem não se refere apenas às imagens "visuais" e elas também não são estáticas. As imagens de todas as modalidades "retratam" processos e entidades de todos os tipos, tanto concretos como abstratos. Elas são construídas quando se mobiliza objetos e estímulos fora do cérebro em direção ao seu interior e também quando ocorre a reconstrução dos objetos a partir da memória, de dentro para fora. Além disso, o autor propõe o esclarecimento do termo "representação", que ele considera como sinônimo de imagem mental ou de padrão neural, que é consistentemente relacionado a algo, quer se refira a uma imagem mental, ou mesmo a um conjunto coerente de atividades neurais em uma região específica do cérebro. Não é possível saber qual o grau de fidelidade entre os padrões neurais e as imagens mentais, porque as imagens se baseiam em mudanças no organismo. Dessa forma, considera-se o objeto, a sua imagem e as interações com ele como reais. Entretanto, a estrutura e as propriedades das imagens vistas são construções do cérebro.

\subsection{A ORGANIZAÇÃO PERCEPTUAL}

Koffka (1983) pontuou que para estudar as propriedades da organização não se deve buscar resposta nos fatos psicológicos, pois esta é considerada como uma incógnita. Para isso, sugeriu como modelo os princípios da Física, 
pois as organizações físicas revelam as características gerais da espécie. Considerando que cada gestalt é percebida como algo a mais do que a simples soma de suas propriedades de tamanho, cor e peso.

A percepção do todo é considerada mais importante que as somas de suas partes, pois em si mesmas, não são significativas. Além disso, muitos outros fatores são responsáveis pela organização perceptual. Um deles se refere ao fato de que, embora haja diversidade nas sensações provocadas pelo ambiente, a percepção das coisas se mantém constante. Por exemplo, independentemente da distância que um objeto esteja, em relação ao campo visual, este será percebido sempre como sendo do mesmo tamanho. A explicação para este fenômeno é, que o estímulo visto, não é o mesmo que o percebido, tanto no que se refere às ilusões visuais quanto às percepções comuns. O significado do que se vê é produto da aprendizagem, por exemplo, quando as nuvens escondem o sol, sabe-se que o sol, ainda está lá, embora não esteja visível (Statt, 1978).

A irredutibilidade da percepção das partes em relação ao todo permite que o cérebro faça as construções de um determinado estímulo com tendência natural à restauração do equilíbrio da forma, proporcionando assim, o entendimento do que foi percebido. Tal fenômeno é orientado pela procura de fechamento, simetria e regularidade. As características relacionadas à permanência do objeto foram estudadas exaustivamente pelos gestaltistas.

Koffka (1983), em relação à análise dos processos estacionários, destacou certas propriedades máximo-mínimo, ou seja, um parâmetro, por exemplo: a configuração esférica da bolha de sabão. Ao considerar que de todas as formas sólidas, a esfera é a que possui a menor superfície para um dado volume ou que o volume é maior que uma dada superfície. Afirma que os máximos e mínimos são sempre relativos às condições existentes, sendo o máximo absoluto infinito e, o mínimo, zero.

Para ilustrar esta ideia, apresentou o exemplo das gotas de água, que, quando suspensas num meio de igual densidade serão esferas perfeitas e, quando estiverem pousadas numa base sólida com pouca aderência, apresentarão um formato esférico ligeiramente achatado. Porém, ao retornarem para o ar adotam nova configuração, que ainda é perfeitamente 
simétrica e oferecendo a mínima resistência ao ar. Ao cair se mostra aerodinâmica e a sua simetria se mantém segundo o princípio máximo-mínimo.

Assim sendo, é possível supor que as organizações psicológicas, que ocorrem sob condições simples, devem ter regularidade, simetria e simplicidade. Além disso, frequentemente existem duas possibilidades equivalentes ao mínimo e ao máximo (a simplicidade de um evento mínimo será diferente da simplicidade de um evento máximo). Quanto à possibilidade sobre qual delas poderia ocorrer em cada caso concreto, vai depender das condições gerais do processo.

Köhler publicou uma importante obra em 1920, que nunca foi traduzida para o inglês, com o título: As gestaltens físicas no repouso e num estado estacionário, no qual as descreveu na Química, Eletricidade e Biologia. Considerou que os campos gestálticos nos fenômenos físicos poderiam ocorrer igualmente em processos cerebrais. Ampliou o conceito de isomorfismo, apresentado inicialmente por Wertheimer em 1912. O isomorfismo sustenta que os fenômenos psíquicos e os processos cerebrais a eles subjacentes possuem forma funcional e propriedades gestálticas semelhantes. Neste sentido, a ação do cérebro opera como um todo e não em processos cerebrais independentes. Assim, as formas de percepção correspondem às formas semelhantes nos processos nervosos do cérebro.

Ehrenfelds afirmou que o todo é mais do que a soma de suas partes. Mas os gestaltistas foram além e asseguraram que o todo é diferente da soma de suas partes e a natureza das partes é determinada pelo todo e não o contrário. Deste modo, a análise deveria ser contemplada de cima para baixo e não de baixo para cima, compreendendo-se que não seria adequado começar pelos elementos e procurar sintetizar o todo a partir dele, mas estudar o todo para que a partir dele seja possível ver quais são as suas partes.

Gazzaniga et. al. (2006), citando estudos atuais e propondo uma análise ainda mais profunda do que a dicotômica relação entre as partes e todo, destaca que os mecanismos perceptivos do cérebro permitem reconhecer um objeto em inúmeras situações, mesmo que as informações sensoriais tenham pouco em comum, como por exemplo, a posição no espaço, a cor ou o tamanho. A variabilidade da informação visual que emana de um objeto se dá 
por múltiplas razões. A informação sensorial depende em alto grau da posição de observação, pois ocorrem mudanças no foco de visão não só quando o indivíduo se movimenta em relação ao seu entorno, mas, igualmente, quando os objetos modificam a sua orientação. Ocorrem mudanças importantes na projeção retiniana da forma e nos componentes visíveis de um estímulo, quando as posições de quem percebe ou do objeto são alteradas. Porém, o percepto não reflete a distorção da informação visual captada pelas vias visuais, ao contrário, ajusta as mudanças causadas por desvios no foco da visão.

Além da constância do percepto relacionado à posição no espaço, também há a constância do objeto relacionada à luminosidade, uma vez que a mudança na iluminação de um objeto leva a uma segunda fonte de variabilidade sensorial. As partes visíveis de um objeto podem ser diferenciadas em decorrência do tipo de iluminação (ex.,: vertical ou lateral) e as variações da intensidade da luz também podem alterar a iluminação das partes de um objeto. Embora as células visuais sejam sensíveis à claridade, 0 sistema perceptual faz os ajustes necessários permitindo o reconhecimento do objeto independentemente da intensidade da luz no ambiente.

Outra fonte de variabilidade se relaciona ao fato dos objetos serem vistos, na maioria das vezes, com outros objetos distintos, porém o sistema perceptual é capaz de diferenciar e dividir rapidamente o cenário em seus componentes. Assim sendo, além de ser capaz de atuar de forma efetiva nas fontes de variabilidade, deve também conciliar o fato de que as mudanças na forma percebida podem refletir mudanças no objeto e, contudo, ainda ser capaz de reconhecer que é do mesmo objeto.

\subsubsection{PRINCÍPIOS FUNDAMENTAIS OU LEIS DE ORGANIZAÇÃO DA FORMA VISUAL}

A maneira como as formas são ordenadas ou estruturadas para a percepção foram denominadas "princípios fundamentais" ou "leis de organização da forma visual" (Köhler, 1968; Koffka, 1983). A seguir serão apresentados alguns destes princípios básicos. 


\section{Pregnância}

Um princípio geral foi denominado "Lei da Pregnância", o qual mantém a formulação de que a organização psicológica será sempre tão "boa" quanto as condições reinantes permitirem. Essa lei não permite uma definição precisa, mas deverá abranger propriedades tais como a regularidade, a simetria, a simplicidade e outros. É chamada de lei da "boa forma" ou simplicidade, que propõe que os objetos são percebidos no sentido de regularidade e simetria. Quando se vê pontos e traços, dependendo da sua distribuição no espaço, ocorre a tendência a associá-los às mais variadas formas. Na Figura 3, inicialmente é percebido um triângulo menor dentro de um triângulo maior. Em análise mais detalhada, são vistas duas formas sobrepostas a de um triângulo e a de um retângulo.

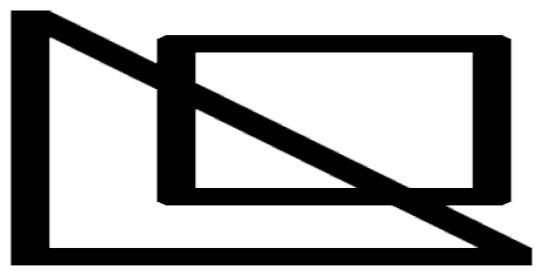

Figura 3. Exemplo de "boa" forma ou simplicidade. Fonte: Leis da Gestalt. (2012, 09 de setembro). Recuperado em 03 de dezembro de 2014, de http://meubloggerdesign2012.blogspot.com.br/

\section{Unidade}

Os elementos podem ser percebidos como únicos ou como integrantes de um todo. Os diversos elementos fazem parte de um todo, mas também podem ser vistos de forma singular. Há harmonia entre os elementos de tal modo que se completam e permitem a percepção de uma nova forma. Na Figura 4 o círculo é percebido individualmente ou como parte de uma nova forma. 


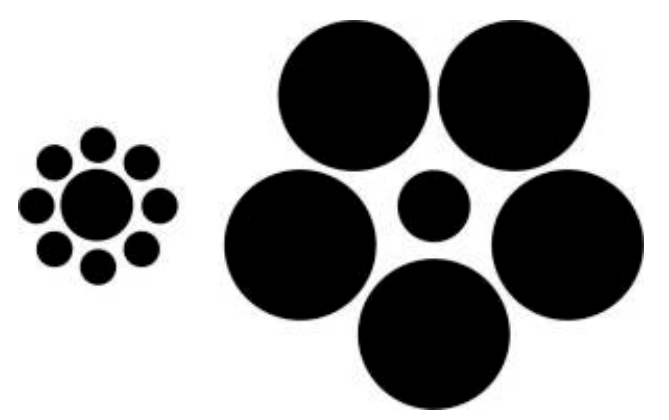

Figura 4. Exemplo de unidade da forma. Fonte: Gestalt Princípios da 'boa forma (2012, 03 de dezembro). Recuperado em 03-12- 2014, de https://ziho.wordpress.com

\section{Segregação}

Consiste em desigualdade dos elementos, isto é, determinado elemento de um conjunto destaca-se muito em relação ao resto no que se refere à forma, cor ou outra característica. São necessárias aptidões perceptivas de separar, identificar, evidenciar ou destacar unidades formais em um todo composto ou em partes deste todo. A Figura 5 contém elementos visuais de cor e forma contrastantes, que permitem o destaque ou a diferenciação de cada elemento.

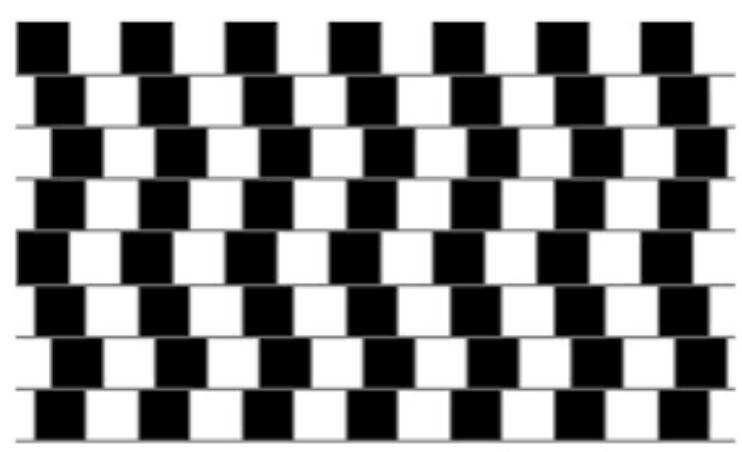

Figura 5. Exemplo de segregação. Fonte: Leis da Gestalt - Você sabe o que é?. (2011, 15 de abril). Recuperadem 03-12- 2014, de jumblex.blogspot.com.br

\section{Proximidade}


$\mathrm{Na}$ lei da proximidade os elementos que estão muito próximos uns dos outros são percebidos como agrupados ou homogêneos. Os estímulos visuais apresentados parecem estar agrupados de acordo com as posições e linhas, porém, apenas foram colocados uns mais próximos do que outros. Na Figura 6 os elementos mais próximos são agrupados formando um todo.

\section{Proximidade}

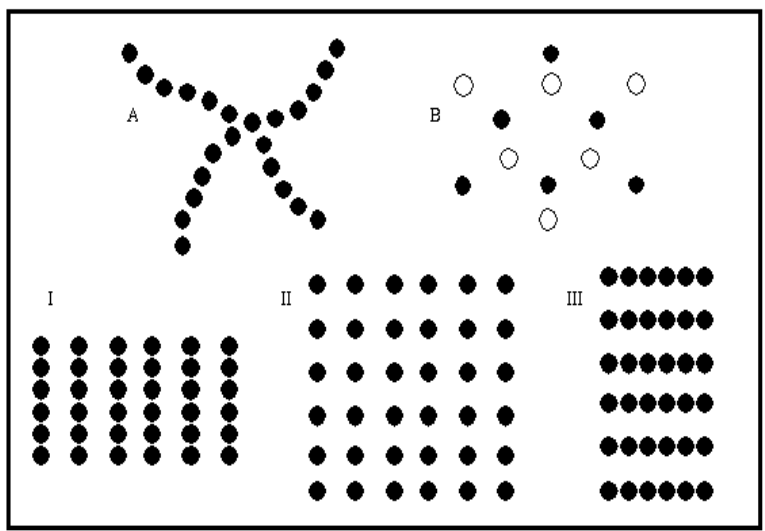

Figura 6. Exemplo de proximidade. Fonte: Teoría Gestalt. trabajo escrito. (2009, 12.de março). Recuperado em 10-04- 2015, de https://almacancino.wordpress.com/2009/03/12/teoria-gestalt-trabajo-escrito-2/.

\section{Continuidade}

A lei da continuidade postula que os pontos que são conectados por linhas retas ou curvas são vistos de uma forma contínua e pertencentes ao mesmo elemento. Serão percebidos na mesma direção, forma e proporção. $\mathrm{Na}$ Figura 7 a linha tracejada é percebida como parte integrante, como uma continuação da forma.

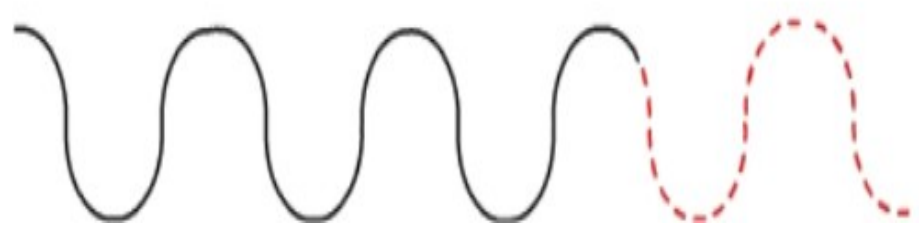


Figura 7. Exemplo de continuidade. Fonte: Leis da Gestalt. (2012, 09 de setembro). Recuperado em 03-12- 2014, de http://meubloggerdesign2012.blogspot.com.br/2012/09/leis-da-gestalt.html

\section{Fechamento}

De acordo com a lei de fechamento, tende-se a produzir contornos ou realizar fechamentos que não existem com base em formas conhecidas. $\mathrm{Na}$ Figura 8 percebe-se um urso em que o princípio de boa forma se completa e há um fechamento do estímulo visual.

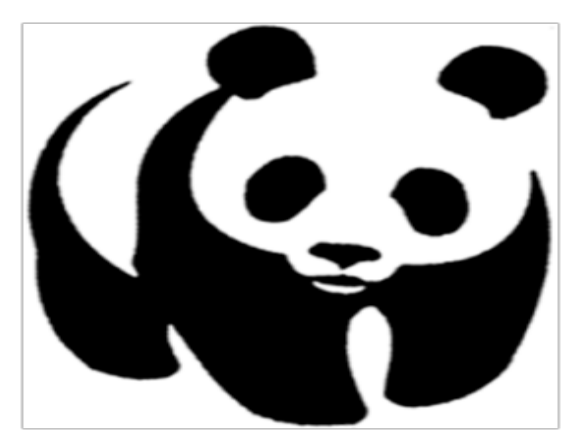

Figura 8. Exemplo de fechamento. Fonte: Cores e Gestalt (2012, 07 de novembro). Recuperado em 03 de dezembro 2014,de http://www. prismacores.wordpress.com/category/sobre-cores

\section{Semelhança}

É a tendência para agrupar os estímulos por semelhanças construindo unidades (generalização). Na Figura 9 percebe-se o agrupamento pelas linhas na vertical e horizontal. Os elementos da mesma forma ou cor tendem a se agrupar formando arranjos visuais harmônicos. 


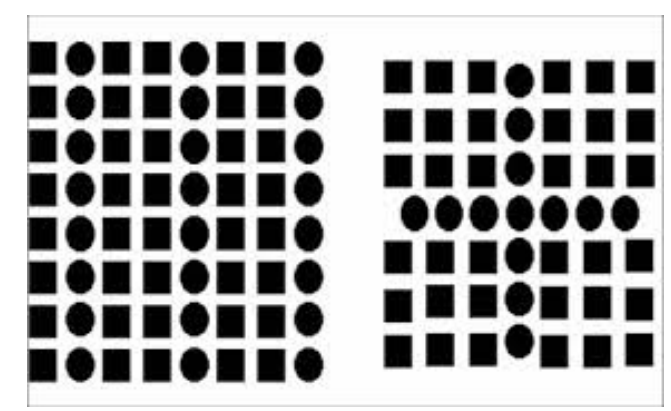

Figura 9. Exemplo de semelhança. Fonte: Ambiente virtual de aprendizagem em arquitetura e design (sem data de publicação). Recuperado em 03 de dezembro 2014,http://www.avaad.ufsc.br/moodle/mod/hiperbook/view.php?id=3013\&target_nav igation_chapter=8038\&groupid=

\section{FUN̄ÇÃO VISOESPACIAL E VISOCONSTRUTIVA}

A função visoespacial é definida como a capacidade de um indivíduo de perceber as relações espaciais entre os objetos, bem como de lidar com as noções de profundidade, solidez e distância. Tal função cognitiva está intimamente relacionada à percepção espacial, a qual pode ser entendida como o resultado final da organização e integração de diversos estímulos sensoriais de maneira a fornecer à consciência um panorama geral sobre as formas do meio externo e suas relações espaciais (Mattei \& Mattei, 2005).

De acordo com Springer e Deutsch (2008) a função visoespacial está relacionada à habilidade de identificar um estímulo no espaço e a sua localização. O papel dos dois hemisférios na imagem mental tem sido uma questão controversa. Ainda que a natureza visoespacial e supostamente não verbal da imagem mental possa indicar uma maior predominância do hemisfério direito, as evidências da lateralização nos processos de imagem mental são multifacetadas. É evidente que as tarefas que envolvem a imagem são altamente variáveis, a maioria está relacionada a funções múltiplas do cérebro, mas algumas condições das tarefas de imagens mentais estão relacionadas ao hemisfério direito.

Um estudo experimental demonstrou que a imagem mental não é um processo mental isolado, mas um conjunto de pelo menos quatro subhabilidades distintas: geração, manutenção, varredura e transformação da imagem. Além disso, as imagens seriam construídas pela organização de suas partes e dois processos diferentes poderiam ser usados nessa organização. Um deles utiliza descrições para organizar as partes, executado mais 
efetivamente pelo hemisfério esquerdo. O outro usa memórias armazenadas de distâncias e posições precisas e é realizado mais efetivamente pelo hemisfério direito. Os estudos sobre as especializações do cérebro, indicam que o lado direito está ligado a funções não linguísticas, que parecem envolver processos visuais e espaciais complexos. A percepção da parte em relação ao todo na discriminação de um estímulo é superior no hemisfério direito.

De acordo com Lacks (2000), o domínio funcional perceptivo-motor, também chamado de habilidades visoespaciais, foi um dos primeiros a serem medidos formalmente como, por exemplo, pelo Teste de Bender. Sua denominação mais recente é habilidade visoconstrutiva, que se constitui na habilidade perceptual e resposta motora no contexto de uma tarefa visoespacial. Este domínio cognitivo envolve a manipulação de peças em conjunto para formar um único objeto. Para um bom desempenho nesta tarefa o indivíduo deve perceber com precisão as relações espaciais entre as partes componentes do estímulo, ser capaz de organizar as partes em um todo e usar as habilidades motoras para reproduzi-lo (Benton \& Tranel, 1993, citados por Lacks, 2000). Um desempenho deficitário pode ocorrer em qualquer uma destas funções. A história da Neuropsicologia mostra que a detecção precoce de alguns prejuízos cerebrais pode ser observada em tarefas visoconstrutivas. Uma vez que as medidas de construção exigem muitas funções cerebrais para completar a tarefa, o mau desempenho pode servir como um marcador para a disfunção em muitas áreas do cérebro e ser causada por várias etiologias. Portanto, as dificuldades de construção podem não evidenciar necessariamente a origem do problema do paciente. Esta falta de especificidade do teste exige observações cuidadosas da história e comportamento do paciente, bem como considerar os resultados de outros testes para distinguir entre as possíveis causas de qualquer dificuldade visoconstrutiva.

As habilidades visoespaciais são complexas e exigem a integração das funções corticais dos lobos occipitais, parietais, frontais e de estruturas subcorticais. São divididas em capacidade visual sensitiva, habilidade visual perceptiva (discriminação e reconhecimento), habilidades visomotoras, atenção 
visoespacial, cognição visoespacial e orientação espacial corporal. Elas podem ser avaliadas por diferentes instrumentos (Andrade et al., 2004).

Segundo Libon et al. (1994) o desempenho nos testes visoespaciais diminui com a idade, ao passo que nos testes verbais permanece relativamente constante. Este padrão foi atribuído a um declínio relacionado à idade no hemisfério direito ou nas funções executivas (FE), que pode estar associado ao declínio pré-frontal cortical. Os autores aplicaram testes cronometrados ou com duração indeterminada das FE e testes visoespaciais, que requerem habilidade integrativa substancial, sendo verificada pouca ou nenhuma habilidade integrativa nos voluntários saudáveis idosos mais novos (74 anos ou menos) e mais velhos (75 anos ou mais). Os grupos diferiram em testes integrativos visoespaciais e em muitos testes das FE, mas não em testes não integrativos. Os resultados dos testes integrativos mostraram altas correlações com testes de funções executivas, mas não com os testes não integrativos. Estes resultados são interpretados como apoio à proposta de que um declínio relacionado à idade nas FE é subjacente ao declínio no desempenho observado no teste visoespacial com o avançar da idade. Também foram discutidas outras questões sobre a relação entre a idade e as FE. Outros estudos indicam a influência do sexo e de alguns fatores internos na percepção e na cognição espacial. Algumas tarefas visoespaciais tendem a favorecer mais os homens e outras as mulheres (Alexander, Packard \& Peterson, 2002). 


\section{NEUROBIOLOGIA DA PERCEPÇÃO VISUAL}

Os estímulos visuais são captados pela retina e dirigidos para os corpos geniculados externos, depois seguem para a área estriada ou área visual primária (V1). Esta área recebe e processa a informação visual de reconhecimento pela forma, cor, movimento, profundidade, distância, etc. Posteriormente passam por áreas especializadas extra estriadas (V2 a V5) ou áreas secundárias, que permitem a associação das informações recebidas anteriormente e a sua identificação posterior. As informações visuais que chegam ao lobo occipital caminham por dois sistemas, um deles, o sistema magnocelular se projeta dorsalmente em direção à região ocipto-parietal e é responsável pela localização do estímulo. O outro sistema, conhecido como parvocelular, se localiza ventralmente e em direção ao córtex ocipto-temporal. Sua função é a de analisar as propriedades do estímulo para a sua identificação (Conselho Federal de Oftalmologia, 2010; Gazzaniga et al., 2006; Gil, 2002).

A visão é uma modalidade sensorial complexa que se divide em várias subfunções ligadas à detecção da cor, do contraste, da forma, do movimento, da orientação, da localização espacial, das dimensões e da tridimensionalidade dos objetos, ou seja, de uma multiplicidade de estímulos, que surgem no campo visual e que são importantes para que a percepção visual se torne consciente (Pereira, Reis \& Magalhães, 2003). Foram identificadas mais de 50 divisões morfologicamente distintas do córtex (denominadas áreas de Brodmann). As divisões propostas são baseadas apenas na diferença da 
arquitetura neuronal ou citoarquitetura do córtex, relacionadas aos tamanhos e às formas dos neurônios em diferentes lâminas e seus dendritos de inclusão. Observa-se que as áreas distintas do cérebro possuem uma citoarquitetura diferente (Martin, 2013). A Figura 10 ilustra o mapa citoarquitetônico de Broadman:

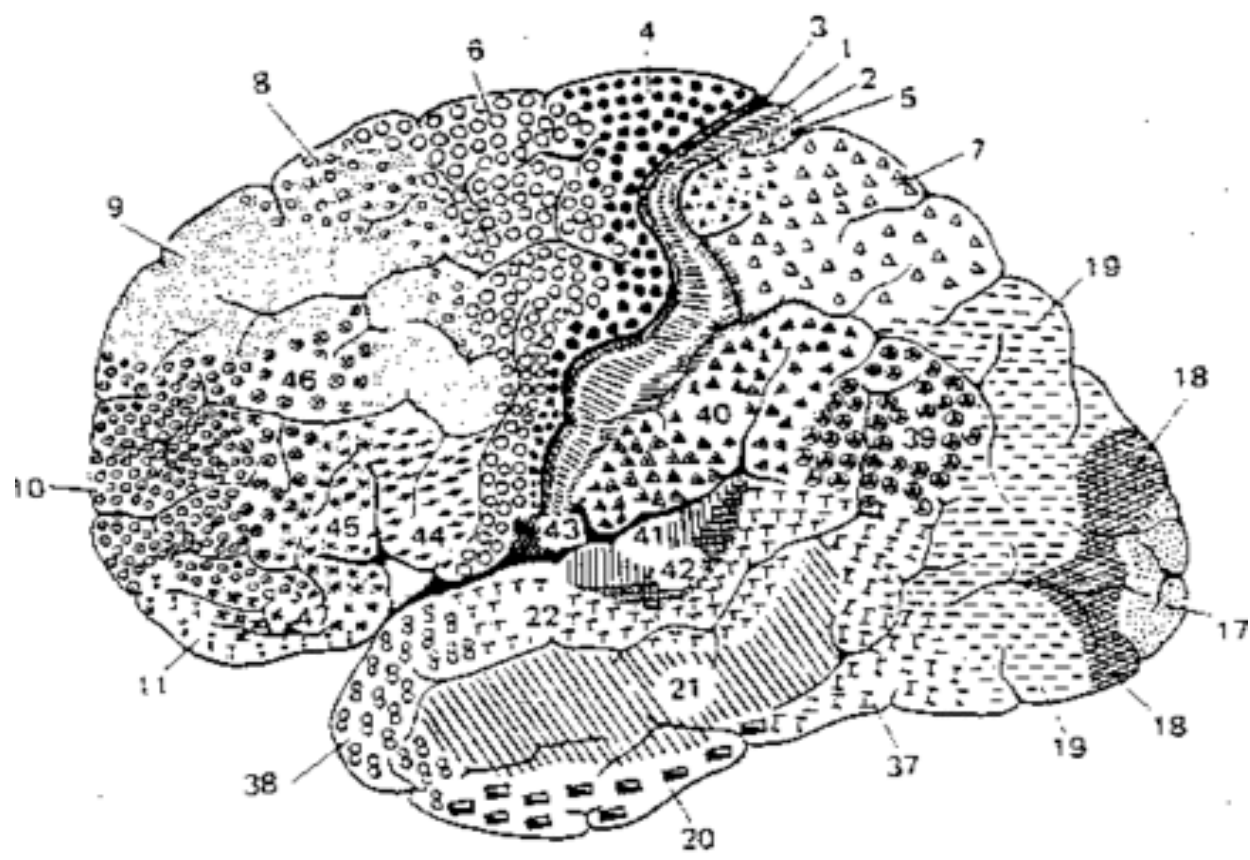

Figura 10. Mapa citoarquitetônico de Brodmann. Fonte: http://www.gmanif.com/files/Brodmann.gif. Acesso em 14 de Março de 2015.

Na Tabela 1 são apresentadas as Áreas de Brodmann relacionadas à percepção visual. 
Tabela1. - Áreas de Broadmann relacionadas à percepção visual

\begin{tabular}{|c|c|c|c|}
\hline Área & Área funcional & Localização & Função \\
\hline 6 & $\begin{array}{l}\text { Córtex motor suplementar; campo } \\
\text { visual suplementar; córtex pré- } \\
\text { motor; campos visuais frontais }\end{array}$ & $\begin{array}{l}\text { Giro pré-central e córtex } \\
\text { adjacente rostral (superior) }\end{array}$ & $\begin{array}{l}\text { Planejamento dos } \\
\text { movimentos dos membros e } \\
\text { olhos. }\end{array}$ \\
\hline 7 & $\begin{array}{l}\text { Área de associação parietal } \\
\text { posterior }\end{array}$ & Lóbulo parietal posterior & $\begin{array}{l}\text { Consciência espacial viso- } \\
\text { motora, percepção }\end{array}$ \\
\hline 8 & Campos visuais frontais & $\begin{array}{l}\text { Giros frontais superior e } \\
\text { médio, lobo frontal medial }\end{array}$ & $\begin{array}{l}\text { Movimentos sacádicos dos } \\
\text { olhos }\end{array}$ \\
\hline $\begin{array}{l}9,10 \\
11,12\end{array}$ & $\begin{array}{l}\text { Córtex de associação pré-frontal; } \\
\text { campos visuais frontais }\end{array}$ & $\begin{array}{l}\text { Giros frontais superior e } \\
\text { médio, lobo frontal medial }\end{array}$ & $\begin{array}{l}\text { Pensamento, cognição, pla- } \\
\text { nejamento do movimento }\end{array}$ \\
\hline 17 & Córtex visual primário & Margens da fissura calcarina & Visão \\
\hline 19 & $\begin{array}{l}\text { Córtex visual de ordem superior, } \\
\text { área visual temporal média }\end{array}$ & $\begin{array}{l}\text { Giros occiptais, medial e } \\
\text { lateral }\end{array}$ & $\begin{array}{l}\text { Visão, cor, movimento e } \\
\text { profundidade }\end{array}$ \\
\hline $\begin{array}{l}20, \\
21\end{array}$ & Área inferotemporal visual & $\begin{array}{l}\text { Giro temporal inferior } \\
\text { Giro temporal médio }\end{array}$ & Visão de formas \\
\hline 37 & $\begin{array}{l}\text { Córtex de associação } \\
\text { temporietal- } \\
\text { temporal média }\end{array}$ & $\begin{array}{l}\text {-Giro temporal médio e } \\
\text { Inferior na junção dos lobos } \\
\text { temporal e occiptal } \\
\text {-Lóbulo parietal inferior (giro } \\
\text { angular) } \\
\text {-Lóbulo parietal inferior (giro } \\
\text { supra-marginal) }\end{array}$ & $\begin{array}{l}\text { Percepção, } \\
\text { leitura e fala }\end{array}$ \\
\hline
\end{tabular}

Fonte: Martin, 2013, p. 47

Segundo Lent (2005), nas áreas de Brodman são detectados os mapas de representação do espaço sensorial, isto é, do mundo visual (visotópico ou retinotópico), do corpo (somatotópico) e do espectro de frequências audíveis (tonotópico). O estudo das propriedades funcionais dos neurônios dessas regiões possibilitou o conhecimento do tamanho e da organização dos seus campos receptores, como também, suas preferências em relação aos estímulos específicos capazes de ativá-los. Esta conduta experimental passou a ser utilizada também nas regiões vizinhas e o resultado foi a descoberta de um grande número de áreas uni e multissensoriais, além das áreas primárias inicialmente estudadas. Além disso, foi revelado que as bordas citoarquitetônicas definidas pelos neuro-histologistas não eram suficientes para 
demarcar as múltiplas áreas detectadas pelo registro de mapas topográficos e propriedades eletrofisiológicas dos neurônios. A multiplicidade de áreas observadas resultou na hipótese de funcionamento hierarquizado em que cada uma utiliza a informação transmitida pela precedente com a finalidade de adicionar complexidade perceptual, levando à reconstrução mental do objeto para a sua posterior comparação com o "banco de imagens" (não só visuais) armazenado na memória.

\subsection{SISTEMA VISUAL}

\subsubsection{ANATOMIA DO OLHO HUMANO}

A percepção exige a interação entre o encéfalo, o corpo e o ambiente. Por exemplo, os movimentos oculares são essenciais para a percepção visual (Ekman-Lundy, 2008; Wurtz, Komatsu, Yamasaki \& Dürsteler, 1990). O olho humano é formado por células e estruturas anatômicas que, em conjunto, permitem captar de modo preciso os estímulos visuais do ambiente e transformá-los em impulsos eletroquímicos, enviados ao cérebro por meio do nervo óptico. Para o processamento dos estímulos visuais é necessário que a luz refletida nos objetos possa ser localizada pelo sistema visual do indivíduo. Além disso, o reconhecimento do objeto deve ocorrer em toda a gama de iluminação, assim como, a identificação das características relacionadas ao tamanho, forma, cores e movimentos. Para haver a percepção dos objetos são necessários detectores sensoriais que respondam à luz refletida. O sistema visual dos mamíferos é iniciado no olho e envolve várias partes do cérebro, assim como, os trajetos que os conectam. No fundo do olho localiza-se a retina com fotorreceptores especializados que convertem a energia luminosa em atividade neural. Quando a luz é captada pela lente do olho, a imagem recebida é invertida e projetada para convergir em um único ponto da retina (Bear, Connors \& Paradiso, 2002; Atkinson, at. al.,1995; Gazzaniga, et. al., 2006). Muitas das funções do olho atuam como uma câmara fotográfica, formando assim as imagens do mundo nitidamente sobre a retina. $O$ processamento da imagem se dá na retina muito antes de qualquer informação 
visual atingir outras partes do encéfalo. A informação visual é distribuída na forma de potenciais de ação por meio dos axônios dos neurônios da retina, que se agrupam em feixe nos nervos ópticos, e chegam a diversas estruturas encefálicas. Alguns alvos dos nervos ópticos podem estar relacionados à regulação dos ritmos biológicos (ciclo diário claro e escuro) e outros ao controle da posição e da óptica do olho. Porém, a primeira estação sináptica na via subjacente à percepção visual está em um grupo de células do tálamo dorsal denominado núcleo geniculado lateral (NGL), que vai levar a informação ao cérebro, e que será interpretada e lembrada (Bear et al., 2002).

De acordo com Atkinson et al. (1995), Carter et al. (2009), Fiori (2008) e Gazzaniga (2005), o sistema visual do olho humano consiste nas seguintes estruturas anatômicas:

1) Íris e pupila: Íris é a parte colorida mais anterior visível do olho, que é formada por pequenos músculos, que podem alterar o tamanho da pupila. A pupila é um orifício formado por um anel muscular e é responsável pela regulação da entrada da luz por meio da contração ou descontração dos músculos.

2) Esclera: é a parte externa e branca do olho, com textura fibrosa e rígida, que dá o formato ao globo ocular.

3) Córnea: é a parte transparente que fica na abertura da esclera, possui uma curvatura que indica os índices de refração do olho. É considerada a janela do olho e serve para a entrada da luz através do cristalino.

4) Lente ou cristalino: é uma estrutura constituída por músculos que vão se contrair ou dilatar para focar a imagem em um ponto específico da retina, onde a imagem será formada (fenômeno de acomodação). Quando a luz passa pelo cristalino a imagem é projetada no fundo do olho, ou seja, na área sensível da retina, onde a imagem é invertida, contudo, ao chegar ao cérebro, é corrigida para a posição normal.

5) Retina: é a membrana interna que contém três camadas de células (ganglionares, amácrinas e bipolares), conectadas por neurônios. É unida à Coróide, uma membrana interna cuja quantidade de vasos sanguíneos permite assegurar a nutrição da íris e da retina. A região 
central da retina é denominada Fóvea (área minúscula e com maior concentração de cones) e responsável por uma visão mais acurada.

6) Fotorreceptores: localizados na terceira camada da retina são formados por dois tipos de células receptoras: os bastonetes, para as imagens em preto e branco, que permitem enxergar durante a noite; e os cones para as imagens coloridas, cuja sensibilidade é menor do que as dos bastonetes, por isso precisam de uma intensidade maior de luz.

7) Nervo Óptico: transporta os impulsos elétricos do olho para a área de processamento visual do cérebro para que o estímulo possa ser interpretado.

8) Humor Aquoso: é um líquido que se encontra atrás da córnea.

9) Corpo Vítreo: é um fluido "gelatinoso" situado no interior do olho, cuja função é manter a retina "colada" na coróide.

\subsubsection{FATORES QUE INTERFEREM NA QUALIDADE DA IMAGEM}

Ao entrar no olho a luz atravessa o cristalino, que a projeta em um ponto específico da retina. Se a luz for projetada antes ou depois deste ponto, a sua qualidade não será perfeita. Podem ocorrer três tipos de distorções a miopia, a hipermetropia e a presbiopia. Na miopia a luz é projetada antes da retina e o olho precisa fazer um esforço muito grande para enviar a luz para o ponto adequado. Por isso é recomendado o uso de uma lente para que a luz seja deslocada para o ponto exato da retina, corrigindo a falha visual. $\mathrm{Na}$ hipermetropia ocorre o contrário, a luz é projetada depois da retina, deste modo, para puxar o raio luminoso para o ponto exato da retina é usada uma lente convergente. A presbiopia ou vista cansada é uma falha visual considerada natural, visto que é decorrente do desgaste das células do cristalino com a idade, na qual ocorre uma falha de focalização da luz, assim, ora a luz está antes da retina, ora depois e o uso de uma lente cilíndrica vai corrigir a alteração, colocando a luz no ponto exato da retina (Bear et. al., 2002; Conselho Federal de Oftalmologia, 2010). 


\section{LINGUAGEM}

Considerando a importância da capacidade para a nomeação verbal ou da escrita no VOT, torna-se relevante compreender alguns dos elementos básicos que constituem a linguagem.

O desenvolvimento da linguagem requer bases estruturais orgânicas e ambientais funcionando, para permitir uma inter-relação sadia entre o cérebro e o ambiente. Neste caso, o ambiente é representado pelos estímulos culturais representativos para a linguagem humana, que possibilita ao homem refletir sobre si mesmo e sobre a sua relação com mundo. Isto significa adquirir um nível de consciência que permite fazer operações mentais de metarepresentação simbólica (Andrade et al., 2004).

Segundo Vygotsky (2001) a decomposição da linguagem em semântica e fonológica não é dada imediatamente e desde o início, surge no processo de desenvolvimento da criança, que deverá diferenciar os dois aspectos da linguagem, tomar consciência da sua diferença e da natureza de cada um deles para prosseguir no processo da consciência da palavra. A princípio a criança não tem consciência das formas e dos significados das palavras. Experiências simples com crianças mostram que, antes da idade escolar, elas explicam os nomes dos objetos pelas suas propriedades (exemplo: vaca, porque tem chifres). Quando questionadas sobre a possibilidade de substituir o nome de um objeto por outro, por exemplo, chamar vaca de tinta, elas respondem que é impossível, porque vaca dá leite e tinta se escreve. A insuficiente delimitação dos dois planos da linguagem (semântico e fonológico) está vinculada às limitações da expressão do pensamento e da sua compreensão nos primeiros anos de vida. A diferenciação entre os dois planos da palavra se desenvolve com o passar dos anos e é acompanhada pela via que o pensamento percorre no curso da transformação da sintaxe dos significados em sintaxe das palavras.

Em uma concepção neurológica a linguagem pode ser definida como uma função cerebral que utiliza elementos verbais, orais e gráficos para a comunicação humana. Está relacionada ao significado das palavras, a sua organização em sentenças, ao modo como elas são produzidas na fala ou na 
escrita e, como podem ser entendidas por quem as ouve ou lê, abrangem a complexidade dos mecanismos cerebrais envolvidos no processo da comunicação (Gazzaniga, Ivry \& Mangun, 2006).

De acordo com Andrade et al. (2004), na análise dos eventos que marcaram o desenvolvimento dos estudos sobre a Neurociência da cognição, nota-se que a linguagem sempre foi um tema dominante, com inúmeras investigações sobre a localização dos mecanismos da linguagem no cérebro e os efeitos das lesões na produção da fala.

A linguagem é considerada por muitos estudiosos uma função complexa constituída por um conjunto de processos que permitem a comunicação. As tarefas nas quais estão envolvidos os mecanismos linguísticos demandam processos complexos que são influenciados pela informação sensorial (Pereira, Reis \& Magalhães, 2003).

$\mathrm{Na}$ abordagem neuropsicológica torna-se necessário integrar conhecimentos clínicos relacionados à natureza do processo patológico, visto que há casos em que o prejuízo se torna crônico, não se alterando ao longo da vida após a lesão cerebral. Em outros casos, na fase aguda da instalação dos sintomas, o quadro é mais animador, como em acidentes vasculares cerebrais (AVC), pois com o passar do tempo, pode haver melhora progressiva do quadro. Porém, em outros quadros ocorre a deterioração progressiva das funções, como na afasia progressiva sem demência, nas alterações da linguagem com o desenvolvimento de uma síndrome demencial ou mesmo nos casos de tumores do cérebro (Andrade et al., 2004).

Uma variedade de alterações de fala e de linguagem pode surgir em decorrência de uma lesão no sistema nervoso central (SNC). O estudo das afasias é considerado um dos que chama mais a atenção sobre as manifestações e distúrbios relacionados à linguagem.

A afasia pode ser definida como uma "alteração no conteúdo, na forma e no uso da linguagem e de seus processos cognitivos subjacentes, tais como percepção e memória". Essa alteração é caracterizada por redução e disfunção, que se manifestam tanto no aspecto expressivo quanto no receptivo da linguagem oral e escrita, embora em diferentes graus em cada uma dessas modalidades (Chapey, 1996 p. 47; citado por Ortiz, 2010). 
Uma série de estudos por PET (tomografia por emissão de pósitrons) revelou a possibilidade de que a recuperação de diferentes classes de palavras seja mediada por diferentes partes do hemisfério esquerdo. O interesse inicial dos estudiosos era descobrir quais estruturas neurais tornam-se ativas, quando uma palavra, que representa uma pessoa ou um objeto é lembrada, é verbalizada silenciosamente ou vocalizada. Embora os estudiosos concordassem que as áreas de linguagem ao redor da fissura de Sylvius (com inclusão das áreas de Broca e Wernicke) participem intensamente da representação fonêmica e da reconstrução de formas de palavras, eles acreditavam que outros locais em muitas regiões do cérebro constituíssem a base do conhecimento conceitual e a localização geral desses locais dependeria de categorias conceituais diferentes. Em um estudo clínico com tarefa de nomeação de 327 itens apresentados visualmente a pacientes com lesões distintas em várias partes dos hemisférios, representando três grupos de palavras: 1) pessoas (fotografias de pessoas famosas), 2) animais e 3) ferramentas. As categorias de animais e ferramentas eram classes de objetos básicos e comuns, diferentemente das fotografias que eram específicas de pessoas famosas. Os resultados deste estudo mostraram um comprometimento na recuperação de uma categoria de palavras que era, na realidade, dependente da localização da lesão no lobo temporal esquerdo. A recuperação anormal de palavras referentes a pessoas foi relacionada a uma lesão no lobo temporal esquerdo; a dos animais, a uma lesão na região temporal inferior e a das ferramentas a uma lesão mais posterior da região temporal inferior, que se prolongava até a junção com os lobos occipital e parietal (Fiori, 2008).

Segundo Kempler (1995, citado por Mansur et al., 2005) a habilidade de produzir itens lexicais pode ser avaliada por provas de nomeação e fluência verbal. As pesquisas tornam evidentes que as dificuldades de nomeação não podem ser explicadas por um único fator. Deste modo, tanto os déficits perceptuais visuais, como os de atenção, de acesso lexical e de deterioração de representações semânticas podem responder por essas dificuldades. 


\subsection{A POLISSEMIA E A HOMONÍMIA: IMPLICAÇÃO PARA A NOMEAÇÃO}

Conforme Ullmann (1977) a polissemia é definida como um componente da fala humana, que pode ocorrer de formas variadas. Trata-se de uma das áreas de estudos semânticos da Linguística sobre uma palavra que pode ter significados múltiplos dependendo do contexto em que ocorre. Destaca-se por cinco procedências em uma língua, são elas: 1) Mudança de aplicação, quando um elemento lexical passa a ter sentidos variados; 2) Especialização num meio social, as palavras abarcam múltiplos significados de acordo com a área de ação e de atuação; 3) Linguagem figurada, quando uma palavra adquire um ou mais sentidos figurados, porém não perde o seu significado original; 4) Homônimos reinterpretados, neste caso, duas palavras têm som análogo e a diferença de significado não é tão grande, de modo a levar à propensão a usar uma única palavra com dois sentidos. São estabelecidas relações de significado entre as palavras; 5) Influência estrangeira, quando ocorre a mudança de sentido de uma palavra já existente num sistema linguístico, por "importação de significado" de uma palavra estrangeira.

As análises semânticas da Língua Portuguesa apresentam definições baseadas nos princípios da polissemia, homonímia, sinonímia e antonímia. Ocorre grande confusão na compreensão dos conceitos que as definem, sobretudo, no que se refere à Polissemia e à Homonímia, pois nos exemplos dados a seguir são semelhantes: Homonímia manga como fruta ou parte da vestimenta; Polissemia letra do alfabeto e letra de música.

Cegalla (1994) define que as palavras homônimas têm a mesma pronúncia e a mesma grafia, porém seus conceitos são distintos. Enquanto as palavras polissêmicas podem ter vários significados, mas se remetem ao mesmo conceito, as homônimas possuem significado diferenciado em duas ou mais formas ou mesma função, porém com a mesma estrutura fonológica e os mesmos fonemas dispostos em ordem. Ela diferencia-se da polissemia, porque os diferentes significados da palavra manga, por exemplo, têm origens diferentes, enquanto no caráter polissêmico as diferentes acepções estão ligadas pelo mesmo conceito, necessitando do contexto para diferenciá-las em seu uso, isto é, a palavra letra, por exemplo, poderá ser utilizada em situações 
variadas, mas sempre será remetida ao sentido de grafia (Bechara 1999; Maia, 1995; Sacconi, 1995)

Guiraud (1986, p. 35, citado por Rocha, 2012) constatou que

A comunicação postula que há um nome para cada sentido, bem como um sentido para cada nome, ainda que fenômenos como a polissemia e a homonímia provem o contrário. Segundo esse autor, cada palavra possui um sentido de base e um sentido contextual, que é evocado e atualizado em determinado contexto: $\mathrm{O}$ sentido de base e o sentido contextual não se superpõem; há sempre um único sentido em uma situação dada, o sentido contextual; à palavra em seu contexto corresponde uma única imagem conceitual. (p.17)

Dias da Silva (1996, citado por Zavaglia, 2003) destaca que a utilização de termos ambíguos, tanto no que se refere às formas como às funções linguísticas, é apresentada em todos os níveis de análise: morfológico, sintático, semântico e pragmático-discursivo.

As relações semânticas de polissemia e homonímia devem ser analisadas de forma criteriosa dada a sua complexidade. Lopes (2007) ao descrever o dilema da delimitação, referente ao limiar semântico, propõe que o "problema" do contexto não poderá ser restrito, porque ao ser delimitado, deixa de considerar que outros sistemas semióticos, por exemplo, a língua de sinais e os gestos de modo geral, possam ter os seus enunciados compreendidos.

Conforme Bräscher (2002), diante de diferentes significados que podem ser extraídos de uma frase ou palavra, o sistema de recuperação necessita diferenciar um significado de outro, determinando, segundo o contexto, qual deles deverá ser aplicado e obtendo, deste modo, maior precisão na resposta dada. A ambiguidade pode ser ocasionada por diversos fatores, como: polissemia, homografia, policategorização, relação contextual e estrutura sintática das frases.

L. Silva (2006) afirma que a ambiguidade é um fenômeno linguístico que permite que uma expressão possa ter interpretações variadas. A ambiguidade 
semântica é definida como distinta da sintática e da fonológica e tem como princípio a homonímia das palavras (Katz, 1971, citado por Lopes, 2007).

O impasse na escolha de informações parcialmente diferentes, mas relacionadas, evocadas por uma única palavra, devem ser reunidas em uma única entrada lexical ou em várias. Em geral, suas soluções não dispensam o recurso à história e a solução do impasse se torna relativamente fácil, se a etimologia das palavras é conhecida e cientificamente acertada (Ilari, 2009).

De modo análogo, a linguagem figurada se constitui também em outra faceta do mesmo processo. Uma palavra pode adquirir um ou mais sentidos figurados sem perder o seu sentido original (B. Silva, 2012)

A palavra bule, por exemplo, é de origem controversa.Supõe-se que venha do malaio bule, recipiente bojudo feito de porcelana e destinado a servir chá, leite, café, etc. Uma outra suposição é que seja do sânscrito buli. Entretanto, sua origem é considerada chula, visto que significa vulva ou ânus, até mesmo no latim bullire,cujo significado é ferver, agitar ou mexer (D. Silva, 2014). Portanto, o contexto cultural das palavras, a história e a sua adaptação devem ser sempre consideradas (Bréal, 1992). 


\section{DISTÚRBIOS DA PERCEPÇÃO VISUAL}

Para que seja possível uma perfeita interação com o mundo exterior não basta possuir órgãos visuais e auditivos íntegros, é necessário o funcionamento adequado dos processos sensoriais e perceptivos nos dois hemisférios cerebrais.

O nível e a localização de um prejuízo nos órgãos externos dos sentidos (ouvidos e olhos) acarretaria danos em uma modalidade sensorial, por exemplo, a auditiva ou a visual, que também poderia ocorrer se os prejuízos fossem nos hemisférios cerebrais. Uma lesão nas áreas do cérebro, responsáveis pela recepção da informação neural proveniente de um órgão sensorial (V1), poderia levar à surdez ou à cegueira cortical. Este tipo de cegueira seria devido aos danos no córtex visual occipital e com frequência das conexões geniculo-calcarinas ou radiações ópticas, que na maior parte das vezes pode ser causada por um infarto bioccipital. Esta pode se instalar de modo abrupto ou lentamente, depois de uma hemianopsia unilateral ou, primariamente, bilateral. A "cegueira" pode ser total ou parcial, porém, significativa. Neste caso não há agravo do fundo do olho e nem dos reflexos fotomotores, mas pode ocorrer perda da capacidade de evocar imagens visuais (Gil, 2002).

As lesões cerebrais que ocorrem na região do córtex visual secundário (V2 a V5) podem comprometer a capacidade de reconhecimento do que é visto, o que se constitui em agnosia visual (Springer \& Deutsch, 1998; Gazzaniga et al. 2006; Gil, 2002).Conforme Ohlweiler e Guardiola (2006), o cérebro possui funções corticais ligadas ao conhecimento denominadas "gnosias". Embora a percepção e a gnosia sejam partes do mesmo processo, não são sinônimos. O sistema que permite o conhecimento que leva à conceituação é chamado gnosia. A percepção visual, por sua vez, é a função que permite a ocorrência da gnosia, por intermédio das características dos objetos, do espaço e do tempo. As alterações das gnosias em crianças estão relacionadas à dificuldade na integração funcional das percepções e são denominadas disgnosias. Quando as alterações das gnosias ocorrem no 
adulto que já possui essas funções desenvolvidas e as perdem em função de um prejuízo neurológico são denominadas agnosias.

Os prejuízos que comprometem as habilidades de percepção visual podem ocorrer em casos de acidente vascular cerebral, em pacientes com histórico de hipertensão crônica, tumores, doenças degenerativas como o Alzheimer ou, ainda, em casos de traumatismos. As dificuldades perceptivas são causadas pela impossibilidade de obter informações por meio de um dos canais de recepção dos sentidos, embora o órgão do sentido não esteja afetado, por exemplo, em casos de indivíduos que não apresentam nenhum tipo de problema visual, porém possuem dificuldade de reconhecimento visual de objetos, lugares e faces (Caixeta, 2010; Gazzaniga, et. al., 2006).

\section{Tipos de Agnosias}

As agnosias são classificadas segundo a modalidade sensorial afetada e os tipos de estímulos que não podem ser reconhecidos. Em casos de agnosias de objetos visuais, o indivíduo não reconhece o objeto. Contudo, tal dificuldade não está relacionada a uma falha na acuidade visual, nem à linguagem (afasia) ou a um déficit intelectual. Todavia, para alguns clínicos, nem sempre ocorrem agnosias visuais nas formas "mais puras", podendo também ocorrer casos de quadros decorrentes de perda mista, ou seja, tanto de ordem perceptiva, quanto sensorial. Nestes casos, embora também sejam reconhecidos como agnosias, é difícil a precisão diagnóstica. Uma agnosia visual é pura quando é limitada ao canal sensorial da visão, pois, às vezes, ela está associada a uma agnosia táctil ou auditiva (Gazzaniga et al., 2006; Gil, 2002).

Nas agnosias visuais graves pode ser observada lesão bilateral nas regiões parietais e occipitais do cérebro ou lesão relacionada a estas áreas no hemisfério esquerdo dominante, juntamente com prejuízos nas vias interhemisféricas. Assim, não haveria conexão com os centros de linguagem do hemisfério esquerdo e com todas as áreas de processamento visual que tenham permanecido intactas. Portanto, um indivíduo com esta agnosia poderia ser capaz de reconhecimento pelo tato, contudo, dependendo do tamanho da lesão parietal poderiam ocorrer falhas em ambas as modalidades. As agnosias visuais podem ser associativas ou aperceptivas. $\mathrm{Na}$ associativa a percepção da 
forma (configuração) e do detalhe está preservada (exemplo: o indivíduo é capaz de realizar cópia de uma figura), entretanto, não há o reconhecimento do objeto copiado, o que é uma deficiência no estágio final do reconhecimento deste. A agnosia aperceptiva se refere a prejuízos tanto no reconhecimento de objetos como na sua integração/sintetização, levando a problemas na percepção da forma e consequentemente na cópia. Trata-se de uma deficiência mais básica na percepção relativa às vias visuais, do que a associativa, que por sua vez indica ser um déficit em um estágio posterior do reconhecimento do objeto (Deutsch \& Springer, 1998; Gazzaniga, et. al., 2006; Gil, 2002). Podem também ocorrer agnosias para as formas de figuras geométricas elementares como círculos, quadrado, triângulo, etc. O paciente não é capaz de identificar a figura e de diferenciá-la. Tal fato explica a incapacidade de identificação das percepções mais elaboradas dos estímulos. Esse déficit pode ser compreendido como um distúrbio sensorial ou como uma variedade de agnosia aperceptiva (Gil, 2002).

Além disso, na agnosia associativa o indivíduo não consegue classificar os objetos em categorias ou funções; os erros podem ser morfológicos, funcionais ou perseverativos. O paciente é capaz de mostrar o uso dos objetos ao ser solicitado verbalmente. Sendo que a identificação das figuras é, em geral, mais difícil do que a dos objetos. Ocorrem dois tipos de agnosia associativa, sendo a primeira conhecida como agnosia associativa stricto sensu, que é caracterizada por erros na denominação visual, sobretudo morfológicos, mas o reconhecimento táctil está preservado e a cópia dos desenhos figurativos é possível, ainda que com grande dificuldade. $O$ desempenho é pior do que a realização do desenho feito por meio de instrução verbal. Os objetos reais são mais reconhecidos do que as imagens, as dificuldades são maiores quando os desenhos estão fragmentados, incompletos ou quando os objetos são apresentados em ângulos pouco habituais. É este tipo de agnosia associativa que está relacionada a uma prosopagnosia, ou a uma acromatopsia e, às vezes, a uma alexia total. A segunda variedade é a agnosia associativa multimodal (ou polimodal), que se caracteriza por erros principalmente semânticos e perseverativos na denominação; mesmo dos objetos de uso diário, que não são reconhecidos e, 
quando solicitados, os doentes não conseguem fazer uma mímica do seu uso, embora tanto os desenhos dos objetos quanto o fato de emparelhá-los comprovam a qualidade do acesso à forma. O déficit de identificação não está tipicamente limitado à esfera visual e pode afetar, também, a palpação ou a audição e, neste caso, o paciente não pode fazer o reconhecimento nem pela forma, nem pelo som. O sistema semântico explorado por via verbal, fica alterado, existe dificuldade para definir palavras concretas, ao contrário das abstratas. O desenho dificilmente é realizado, quando solicitado verbalmente. Estão associadas à anomia das cores e à alexia sem agrafia (Gil, 2002, Gazzaniga et al., 2006).

A prosopagnosia é definida como a incapacidade do paciente em reconhecer os rostos de familiares e o próprio rosto em um espelho ou fotografia, porém, é capaz de descrever um rosto desconhecido e de reconhecer a pessoa pela voz ou pelas roupas (Fiori, 2008; Gazzaniga et al., 2006; Lent, 2005).

Sacks (1997) relatou o caso de um homem que sofria de agnosia visual e que um dia chegou a confundir a cabeça de sua esposa com um chapéu. Em outro caso, descreveu a ocorrência da agnosia visual em três membros da mesma família, que apresentavam características comuns, porém não no mesmo grau. Em um deles, a paciente chegou a passar em frente ao seu marido, olhando em seu rosto, mas não foi capaz de reconhecê-lo. Contudo ela o reconhecia facilmente em situações ou lugares onde esperava encontrá-lo. Além disso, também era capaz de reconhecimento imediato de pessoas ao ouvir suas vozes.

Em outros quadros de déficits perceptivos visuais, derivados de disfunções do sistema nervoso central, os pacientes não são capazes de perceber as cores, porém esta dificuldade não ocorre com tanta frequência quanto os casos relacionados aos fatores genéticos como nos casos dos daltônicos. Os daltônicos monocromáticos, possuem um só tipo de cone e só podem ver um tipo de cor, os dicromáticos, possuem dois tipos de cones e são cegos para as cores vermelho/verde ou azul/amarelo, ou mesmo os tricromáticos anômalos, que são indivíduos que possuem os três tipos de cones, porém percebem o tom das cores alteradas. Os distúrbios de percepção 
visual mais raros são conhecidos como acromatopsia, que significa "sem matiz". Esses pacientes enxergam o mundo sem cor, como se tudo fosse branco, pardo, cinza ou preto (Gazzaniga et al., 2006; Zihl, 1989).

Segundo Gazzaniga et al. (2006), em 1917 Riddoch descreveu a perda da habilidade de perceber visualmente um movimento, que é conhecida como acinetopsia. Neste caso, o paciente vê o mundo como tomadas fotográficas rápidas. Assim sendo, ao invés de enxergar as coisas em movimento contínuo, o paciente vê os objetos em apenas uma posição, para depois vê-lo em outra, e assim sucessivamente. Há descrição de um caso do início do século XX, em que um paciente descrevia que percebia o mundo como achatado, indicando dificuldade na percepção visual de profundidade.

A incapacidade de reconhecer dois ou mais estímulos ao mesmo tempo foi descrita por Balint em 1909, e recebeu o nome de paralisia psíquica do olhar. De acordo com Gil (2002) há três elementos semiológicos associados a esta síndrome, sendo:

1) Paralisia psíquica do olhar ou apraxia óptica: Refere-se à incapacidade do indivíduo de fixar o olhar em um alvo no seu campo visual periférico, ainda que o objeto seja visto e reconhecido. A dificuldade em desviar o olhar de um objeto para o outro está relacionada ao déficit do movimento sacádico (movimentos oculares rápidos utilizados para o recolhimento das informações visuais). O nistagmo optocinético (fenômeno ocular rítmico, involuntário, inconsciente e automático) é abolido neste caso.

2) Ataxia óptica ou ataxia visomotora: Apresenta-se como um prejuízo em atingir um alvo, ao se orientar pela visão. Observa-se o fracasso do indivíduo ao tentar pegar um objeto colocado no seu campo de visão. Trata-se de uma dificuldade bilateral que pode ser acentuada em uma das mãos, a apreensão se torna mais difícil no hemicampo visual oposto à mão mais atingida. Para o diagnóstico é necessária a exclusão de problemas associados à acuidade visual, à força muscular, à sensibilidade proprioceptiva e à coordenação dos membros. A ataxia óptica sugere uma alteração das conexões homo e heterolaterais entre o córtex visual e o motor. 
3) Déficit da atenção visual ou desorientação visual: Caracteriza-se por déficits das estimulações periféricas na solicitação da atenção visual. Recebeu a denominação de simultagnosia ou agnosia simultânea, por Wolpert em 1924. Ocorre a perda da capacidade de elaboração de sínteses de modo congruente. $O$ indivíduo não consegue ter a percepção do todo. A dificuldade consiste na atenção visual, porém, quando os estímulos são apresentados de forma isolada, os detalhes, os fragmentos e, até mesmo os objetos, podem ser percebidos. Os portadores deste tipo de prejuízo não sofrem de perturbações motoras ou sensitivas ou de anomalias do campo visual (Mattei \& Mattei, 2005). 


\section{TESTES QUE AVALIAM AS FUNÇÕES VISOESPACIAIS E VISOCONSTRUTIVAS}

Atualmente existem vários instrumentos para avaliar as habilidades de construção visoespacial e entre os mais utilizados estão: os subtestes Cubos Raciocínio Matricial e Armar Objetos das Escalas Wechsler, o Teste de Matrizes Progressivas Raven, o Teste do Desenho do Relógio e as Figuras Complexas de Rey.

O subteste de Cubos das Escalas Wechsler apresenta uma tarefa com tempo limite em que o examinando reproduz inicialmente modelos bidimensionais de duas cores (vermelho e branco) com o uso de cubos bicolores, sendo o grau de dificuldade dos itens progressivo. O subteste Raciocínio Matricial é composto de quatro tipos de tarefa de raciocínio não verbal, sendo estas: completar padrões, classificação, analogia e raciocínio serial. O examinando tem a sua frente uma matriz, em que falta uma parte e deve apontar ou dizer o número correspondente à parte que completa a matriz entre cinco opções. O subteste Armar Objetos apresenta quebra cabeças, em que as partes devem ser reunidas de forma correta para retratar objetos comuns. Mede a capacidade de construir ou reunir elementos no espaço com a finalidade de formar uma unidade (Wechsler, 1997).

O Desenho do Relógio é um teste muito utilizado para a triagem clínica, como auxílio no diagnóstico para as deficiências da função visoespacial e de construção. Para esta tarefa é solicitado ao paciente que desenhe um relógio com todos os números e depois, pede-se para desenhar os ponteiros marcando 20 minutos para ás 4 horas (Spreen \& Strauss, 1998). De acordo com Atalaia-Silva e Lourenço (2008), embora não haja um modo único padronizado de administração e correção, esse teste é amplamente aceito como um instrumento de rastreio cognitivo.

As Figuras Complexas de Rey foram idealizadas por André Rey, em 1942, para auxiliar no "diagnóstico diferencial entre a debilidade mental constitucional e o déficit adquirido, em consequência de traumatismo crânioencefálico" (Rey,1999, p. 9). Contudo, foi Osterrieth que, em 1945, ampliou os estudos genéticos da prova. O Teste das Figuras Complexas de Rey, 
apresentado em duas formas A e B, permite a avaliação de crianças e adultos. As atividades requeridas no teste envolvem as habilidades perceptivas e de memória visual (Rey, 1999). 


\section{O TESTE HOOPER DE ORGANIZAÇÃO VISUAL}

\subsection{DESCRIÇÃO GERAL}

O Teste Hooper de Organização Visual (VOT) foi publicado em 1958 e revisado em 1983. Porém estudos preliminares de padronização foram realizados em 1948 por Hooper com o objetivo de comparar o desempenho de uma amostra normativa de participantes em três grupos etários diferentes.

O VOT é um instrumento de avaliação breve utilizado para medir a capacidade de adolescentes e adultos para discriminar e organizar estímulos visuais, cuja tarefa é particularmente indicada para avaliar pacientes com prejuízos neurológicos. O teste consiste em um conjunto de 30 estímulos de figuras variadas, não coloridos, que são apresentadas fragmentadas e distribuídas em cartões com fundo branco. Os estímulos são mostrados um a um e solicita-se ao examinando para identificar visualmente e nomear qual figura seria formada, se as partes do desenho fossem juntadas corretamente. O desempenho eficiente no teste depende principalmente de habilidades visuais de análise e síntese, além da capacidade para nomeação verbal ou escrita.

A pontuação total bruta é obtida somando-se o número de respostas corretas, que recebem crédito de um ou de meio ponto, para respostas parcialmente corretas, que ocorrem com frequência moderada na população normal. A pontuação bruta total é convertida em nota $\mathrm{T}$ com base na idade correspondente e nível educacional.

O teste foi projetado para avaliar as limitações decorrentes de prejuízos neurológicos. Às vezes, os erros são cometidos por indivíduos que não estão motivados para a realização da tarefa ou que têm dificuldades para sustentar a atenção. O teste tenta minimizar tais fatores situacionais. Os itens começam em um nível muito fácil, têm em sua estrutura características que se assemelham a um jogo e retratam figuras que são muito familiares para a maioria dos examinandos e que poderiam ser facilmente reconhecidas, se mostradas em sua configuração habitual. O teste pode ser aplicado em grupos 
ou individualmente. O tempo de administração pode ser de menos de 15 minutos. O critério para a interrupção é de cinco erros consecutivos.

Alguns cuidados na utilização do teste foram pontuados pelo autor, considerando que a avaliação da disfunção neurológica é uma tarefa de grande complexidade e que exige do profissional sensibilidade clínica e um conhecimento profundo da literatura clínica e da Neuropsicologia. O VOT é usado como um instrumento de rastreio ou como uma medida de uma área específica de funcionamento cognitivo, a integração visoespacial. Portanto, recomenda-se que o seu uso não seja isolado e que devem ser aplicados outros métodos, como procedimentos diagnósticos neurológicos especializados e baterias com outros testes mais abrangentes, para complementar a investigação neuropsicológica. Além disso, diversas limitações específicas devem ser consideradas ao interpretar os resultados do teste. Em primeiro lugar, ele não é uma medida "pura" da capacidade de integração visoespacial, já que o desempenho adequado também exige o desenvolvimento de vocabulário elementar e a capacidade de nomear objetos comuns. Em segundo lugar, a base de dados das pesquisas disponíveis no momento não é muito grande para o uso em crianças abaixo de 12 anos. Embora tenham sido realizados alguns estudos normativos para esta população, ainda não há suporte empírico suficiente para justificar o uso deste teste para decisões clínicas ou para a classificação nessa faixa etária. Pesquisas recentes mostram que o desempenho no teste é significativamente influenciável por uma série de variáveis, especialmente a idade, a inteligência e o nível de escolaridade. Assim, Hooper (1983) sugere que para obter uma medida mais sensível da disfunção cognitiva é importante a aplicação de pontuações de ajustamento, ao invés de pontuações brutas, principalmente no que se refere às pessoas idosas.

\subsection{PADRONIZAÇÃO ORIGINAL}

Estudos preliminares de padronização foram realizados em 1948 por Hooper. A amostra foi composta de: 30 estudantes do ensino médio (11 
meninos e 19 meninas) com idade média de 13,9 anos; 166 estudantes universitários (120 homens e 46 mulheres) com idade média de 21,8 anos; e 28 voluntários residentes em um lar para idosos (23 mulheres e cinco homens) com idade média de 76,8 anos. Os resultados mostraram que os estudantes do ensino médio obtiveram média de 25,43 e desvio padrão de 5,04, os universitários tiveram média de 25,64 e desvio padrão de 3,98, e, por sua vez, os idosos normais ficaram com média de 18,57 e desvio padrão de 4,31. Estes resultados foram utilizados para o estabelecimento de notas de corte, o que minimizou os erros de classificação dos indivíduos em cada grupo etário.

Baseado em uma nota de corte de 20, o VOT classificou com precisão 97\% dos estudantes do ensino médio e 94\% dos estudantes universitários, porém somente 33\% dos idosos. Quando a nota de corte foi aumentada para 25, as taxas de precisão na classificação diminuíram para 66\% para os estudantes do ensino médio, 72\% para os universitários, e 21\% para os idosos.

Um outro estudo de padronização, com um número maior de participantes foi realizado por Mason e Ganzler (1964, citado por Hooper, 1983) com base em uma população masculina de um hospital de "veteranos". A amostra foi obtida em quatro grupos diferentes: 187 pacientes com doenças pulmonares, 60 pacientes internados para cirurgia geral; oito funcionários do hospital e cinco trabalhadores voluntários do hospital, todos com mais de 64 anos. Os dados estavam incompletos ou indisponíveis em uma parte da amostra, uma vez que o relato dos resultados foi com apenas 231 casos. Os critérios de exclusão usados foram: histórico de doença psiquiátrica, alcoolismo, epilepsia, traumatismo, doença cerebral ou outros fatores que poderiam sugerir doença mental ou danos cerebrais. A distribuição de idade foi representativa da faixa etária adulta. Da amostra total, 10\% tinham menos de 30 anos de idade, 26\% entre 30 e 39, 26\% entre 40 e 49 anos, 16\% entre 50 e $59,17 \%$ entre 60 e 69 , e $6 \%$ tinha 70 anos ou mais. O nível de escolaridade média foi de aproximadamente 11 anos. A média total da pontuação bruta para a amostra de padronização foi de 25,71 (DP =4,78). Foram calculadas as normas em notas $\mathrm{T}$ (com a média $=50$, DP $=10$ ) para cada valor do escore bruto. Como auxílio para a interpretação, a posição das notas T foi invertida, para que as maiores notas $\mathrm{T}$ representassem uma maior probabilidade de 
disfunção neurológica. As notas $T$ variaram de 41 (para um resultado bruto perfeito equivalente a 30 pontos) a 104 (para uma pontuação bruta de 0).

\subsection{ESTUDOS DE PRECISÃO E VALIDADE DO VOT}

Foram realizados diversos estudos visando à análise da precisão??? do VOT nas populações clínica e não clínica. Nas pesquisas desenvolvidas por Hooper (1948) foram encontradas estimativas de precisão com uma amostra de 166 estudantes universitários (120 do sexo masculino e 46 do feminino), com média de 21,8 anos. Foi obtida uma correlação de 0,82 entre as metades do teste, após a correção pela fórmula Spearman-Brown. O erro padrão de medida foi de 1,69. Em outro estudo em 1952 de validade, comparou quatro grupos diferentes: um grupo de pessoas consideradas "normais", um de neuróticos, um de esquizofrênicos e outro com prejuízo orgânico. Cada um dos grupos era formado por 70 pacientes do sexo masculino, todos recebiam tratamento em um Hospital de Veteranos. Os resultados mostraram que o grupo com prejuízo orgânico teve a menor média $(13,7)$, comparado ao dos de neuróticos $(25,6)$, ao dos esquizofrênicos $(25,1)$ e o grupo controle $(25,8)$. A Análise de Variância indicou diferenças significativa entre as médias dos grupos $[F(3,266)=203,00, p<0,001]$. Os resultados dos testes $t$ individuais confirmaram a capacidade do teste em discriminar indivíduos com deficiências neurológicas inespecíficas do grupo normal e do psiquiátrico.

Em 1958, Hooper investigou a precisão do teste em uma amostra mista de 73 pacientes psiquiátricos de um hospital psiquiátrico estadual, aos quais foi aplicado o VOT como parte inicial de uma bateria de avaliação. A média de idade foi de 34,6 e a de escolaridade de 12,2 anos. Quanto ao diagnóstico foram incluídos diversos quadros psiquiátricos menos graves, sendo: 58,9\% neuróticos mistos e $41,1 \%$ com transtornos de personalidade. O coeficiente de precisão??? foi de 0,78 , com um desvio padrão de 2,58 e um erro padrão de 1,21 .

Gerson (1974, citado por Hooper, 1983) reproduziu e estendeu essas estimativas de precisão para os mais diversos grupos clínicos. Aplicou o teste a três amostras diferentes: um grupo com prejuízos neurológicos $(n=16)$, um de 
pacientes psiquiátricos internos com grave perturbação mental ( $n=19)$, e um normativo ( $n=33$ ). O grupo com diagnóstico de disfunção orgânica incluiu os indivíduos com uma variedade de síndromes cerebrais crônicas ou agudas. Cada paciente foi diagnosticado duas vezes: Primeiro foi internado com diagnóstico de lesão cerebral e, em seguida, este diagnóstico foi confirmado com base em observações clínicas. Além disso, 50\% dos casos tiveram um EEG anormal e $18 \%$ exames cerebrais questionáveis ou anormais. Os pacientes psiquiátricos internados foram diagnosticados como esquizofrênicos agudos ou crônicos, com base em uma combinação de análise clínica e padrões de perfil do MMPI. Foi obtido neste estudo um coeficiente global corrigido de precisão de 0,80, indicando que $80 \%$ da variação nos resultados do teste é atribuído à "variância verdadeira" nos traços medidos pelo VOT e os restantes 20\%, ao erro de mensuração (Hooper, 1983). Os desvios padrão para os três grupos foram um pouco superiores aos relatados por Hooper (1948, 1958) em estudos realizados anteriormente e os erros padrão de medida também foram mais elevados: 1,90 para os pacientes com encefalopatia, 1,91 para os pacientes com esquizofrenia aguda e crônica, e 2,22 para a amostra normativa.

A pesquisa de Wang (1977) também visou, além dos estudos de validade, constatar a possibilidade da existência de diferenças hemisféricas na execução do VOT em pacientes com lesões cerebrais. O estudo foi realizado com 49 pacientes com lesão cerebral (15 com lesões no hemisfério esquerdo, 19 com lesões no hemisfério direito e 15 com lesões bilaterais) e 17 pacientes sem diagnóstico de prejuízo cerebral. Os resultados do trabalho indicaram que os pacientes que não apresentavam prejuízo cerebral tiveram um desempenho significativamente melhor (pontuação média de 22,4) do que os pacientes com diagnóstico de lesões cerebrais (pontuação média de 12,2). No entanto, as diferenças entre os grupos de pacientes com lesão cerebral não foram significativas. Diante deste resultado o autor concluiu que o VOT parece ser útil para identificar prejuízos cerebrais, mas, limitado no que se refere a determinação da lateralização hemisférica. Sugeriu-se também que os dois hemisférios formam uma conexão funcional que auxilia na organização visual, considerando que a habilidade de nomear as figuras envolve a linguagem, 
assim como, as habilidades visoespaciais específicas. As diferenças de idade entre os vários grupos não foram controladas no estudo, portanto, o autor enfatiza que as diferenças entre as idades podem ter atenuado as diferenças encontradas, visto que a amostra prejudicada neurologicamente era mais jovem, em média, do que o grupo controle, as diferenças de idade podem ter atenuado as diferenças entre os grupos. Além disso, propôs um diagrama hipotético para descrever a dinâmica funcional da capacidade de síntese visual medida pelo VOT.

Hooper destaca que os resultados globais encontrados nestas pesquisas sugerem que a precisão do VOT se encontra dentro dos limites aceitáveis para o uso clínico. Embora as estimativas de precisão teste-reteste não tenham sido apresentadas, sugeriu que para aumentar a utilidade do teste é importante estender os atuais estudos de precisão, incluindo investigações sobre a estabilidade para vários intervalos de tempo e concordância entre os resultados da administração individual e em grupo. Também recomendou estudos de concordância entre juízes diferentes para os indicadores qualitativos.

Eisenman e Coyle Jr. (1965) pesquisaram ausência de falsos positivos no VOT com 23 estudantes de enfermagem e não detectaram a presença de nenhum caso falso positivo nesta amostra. Também observaram pontuações consistentemente superiores às relatadas no manual VOT para a população normal. A pontuação média foi de 28,5 pontos para os 23 participantes, sendo que cinco deles alcançaram a pontuação máxima de 30 pontos. Também não encontraram nenhuma pontuação abaixo de 20, o que foi considerado por Hooper como nota de corte em 1948. Além disso, neste estudo foi utilizada a nota de corte de 25 pontos e, ainda assim, não encontraram nenhum caso de falso positivo.

Boyd (1981) encontrou correlação entre o VOT e o Teste Peabody, sugerindo que a inteligência tem influência no seu desempenho. O autor controlou as váriáveis idade, educação e inteligência Os participantes foram: um grupo com prejuízo cerebral que composto por 40 pacientes diagnosticados com lesões cerebrais, 24 com doenças neurológicas crônicas, como a esclerose múltipla ou lesão cerebral, há mais de quatro meses antes da aplicação do teste (permitindo, assim, o efeito de 
recuperação espontânea). Para determinar a capacidade do teste em auxiliar na localização hemisférica, os pacientes com lesão foram divididos em três subgrupos: 18 pacientes com dano primário hemisférico direito, nove com patologia hemisférica esquerda e 13 com qualquer dano difuso ou medial. $O$ grupo sem histórico de patologia $(n=40)$ consistiu de pacientes com distúrbios neuróticos ou afetivos e pacientes não-psiquiátricos. Foram aplicados o VOT e o Teste de Vocabulário de Figuras Peabody (PPV). As pontuações obtidas no PPV não diferenciaram entre os grupos com prejuízos neurológicos dos que não apresentavam, o que indica que ambos tiveram êxito na prova de inteligência verbal igualmente. As análises posteriores revelaram uma diferença significativa entre as médias no VOT para o grupo com prejuízos neurológicos (média de 23,3 pontos e DP de 3,99) em relação ao sem prejuízos (média de 26,5 pontos e DP de 2,4), $t(39)=4,50, p<0,001$

Para minimizar o número de falsos negativos nas classificações foi adotada uma nota de corte de 25,5 pontos. Isto resultou em uma taxa de classificação global correta de 73,8\%. Não houve diferenças significativas entre os subgrupos com diagnóstico de lesão, no que se reporta às áreas de localização ou de lateralização específicas da disfunção neurológica. Entretanto, houve uma diferença significativa entre os pacientes com lesões mais difusas do que nos com lesões menores e mais focais. Boyd concluiu que o VOT pode oferecer informações válidas e úteis quando usado junto com outros dados de investigação clínica. Porém, recomenda que a nota de corte seja analisada considerando outros fatores, como idade, nível de escolaridade, inteligência, além do contexto em que o teste foi administrado.

Tamkin \& Jacobsen (1984) realizaram uma análise de regressão múltipla, constatando que apenas a idade e o QI foram responsáveis por uma quantidade significativa da variância nos escores do VOT. Assim, estes resultados defendem a necessidade do uso de normas considerando a idade e o QI. No que se refere a análise da percentagem de predição relativa ao sucesso de um teste em detectar o que se propõe para os três tipos de testes usados isoladamente e em combinação (o Weigl, o VOT e o Benton), foi observado que a taxa de sucesso é aumentada pela combinação da utilização 
dos três, ou seja, a validade preditiva é reforçada pela combinação dos três testes em um índice preditivo (Tamkin \& Kunce, 1985).

Ricker e Bradley (1995) avaliaram a influência da nomeação no desempenho do VOT em 50 pacientes encaminhados para avaliação neuropsicológica, que foram submetidos consecutivamente ao VOT, ao WAIS$\mathrm{R}$ e ao Teste de Nomeação Multilingual de Afasia (VNT). As análises de regressão múltipla hierarquizada indicaram que o fator de organização perceptual representou $48 \%$ da variação no desempenho do VOT em relação à nomeação. Também foi administrado um teste composto de nomeação das figuras montadas do VOT a outros 50 pacientes. Os resultados indicaram que a organização perceptual foi responsável por uma quantidade significativa de variância no VOT (44\%), porém, quanto a comparação da capacidade de nomeação para os objetos do VNT não foi observada relação significativa com o desempenho no VOT. Os resultados sugeriram que o VOT é uma medida válida para a avaliação da organização perceptual e que a capacidade de nomeação não interfere de modo significativo.

Kirk (1992) apresentou dados normativos do VOT de 434 crianças com desenvolvimento normal e desempenho adequado em tarefa de nomeação, avaliado pelo Teste de Nomeação de Boston (BNT). Foram observadas diferenças em relação à idade e gênero. A capacidade das crianças de seis anos para identificar objetos comuns com informação visual fragmentada aproximou-se dos níveis limítrofes obtidos pelos adultos. Os meninos de até 12 anos de idade atingiram níveis de desempenho de adultos, mas as meninas não chegaram a esses níveis. Isto sugere que a capacidade de organização visual pode ter um curso mais longo de desenvolvimento em meninas do que em meninos. A versão reordenada para criança do VOT foi proposta com base na análise da pontuação das respostas dos 218 meninos avaliados. Spreen e Strauss (1998) comentaram a pesquisa de Kirk (1992), e relataram que nos estudos de Seidel não foram encontradas diferenças entre os sexos até 11 anos.

Mertem e Beal (1999) em uma amostra de 320 pacientes neurológicos de lingua alemã, com idade média de 51,3 anos, observaram pontuação média no teste de 18,8 ( $D P=6,2)$. As estimativas de consistência interna do total da 
escala produziu resultados aceitáveis $(>0,88)$. E, embora tenham considerado o teste útil para avaliar a disfunção visoperceptual e visoespacialorganizacional, as características dos itens do teste não foram consideradas satisfatórias, pois a posição dos itens não correspondeu à sua ordem de dificuldade. Além disso, na sua forma atual, os critérios de pontuação de alguns itens parecem ser arbitrários e não fundamentados em dados empíricos. A revisão do teste é proposta pelos autores para melhorar suas propriedades psicométricas.

Greve, Lindberg, Bianchini e Adams (2000) destacam questões de validade de construto do VOT, no que se refere ao papel da habilidade de nomeação dos objetos. O seu estudo mostrou que esta habilidade e a percepção visual são necessárias para um desempenho adequado. Apesar da capacidade de nomeação estar implicada em quase $10 \%$ da variâcia do teste, 0 seu rebaixamento teve pouco impacto sobre o desempenho no VOT. Assim, concluem que apesar da natureza multifatorial do teste, ele é válido para avaliar a capacidade espacial, particularmente em contexto de avaliação neuropsicológica na qual a linguagem pode ser verificada por outros meios.

Mesulam (2000) obteve em adultos jovens uma média de 25 pontos, e considerou que acima de 65 anos uma pontuação média de 22 pontos pode ser considerada normal. Observou que o nível educacional pode influenciar no desempenho do VOT. É observado que alguns erros cometidos neste teste que não impliquem em déficit primário de síntese perceptiva ou de uma afasia (falha em nomear os objetos, apesar da capacidade de reconhecimento estar preservada). Podem ser causados por impulsividade (conclusão precipitada baseada em uma parte da figura) ou por déficits visuais elementares que interferem na entrada da informação.

Paul et al. (2001) avaliaram o desempenho de pacientes com diagnóstico de demência vascular subcortical nos seguintes testes: Teste Hooper, Teste de Nomeação de Boston, os subtestes de Cubos e o Completar Figuras da Escala de Inteligência Wechsler para Adultos, além das Figuras Complexas de Rey (cópia). Foi observada em geral a ocorrência de desempenho rebaixado destes pacientes em cada uma das tarefas cognitivas 
em comparação aos dados normativos, com dificuldade mais pronunciada no Teste de Nomeação de Boston.

Lopez, Lazar e Sindy Oh (2003) pesquisaram em uma amostra de 281 participantes que apresentavam deficiência cognitiva, normais e com estado cognitivo indeterminado. O resultado apresentou consistência e precisão internas e na análise de itens do VOT. O coeficiente alpha para a amostra total foi de 0,882 . A análise dos itens constatou que 26 dos 30 itens mostravam boa discriminação entre os pacientes. Além disso, a precisão entre avaliadores mostrou coeficientes elevados para três $(0,992)$, avaliadores $(0,988)$ e um avaliador $(0,977)$. Por isso, os autores concluíram que o VOT é um teste psicométrico válido e confiável.

Lezak, Howieson, Bigler e Tranel (2012) citam algumas conclusões de outros estudos com o VOT que serão apresentados a seguir:

Os casos de tumores do cérebro e derrame tendem a ser associados a pontuações muito mais baixas do que nos de traumatismo crânio-encefálico (Boyd, 1981). Em uma amostra com Alzheimer, relativamente poucos pacientes tiveram desempenho dentro dos limites normais, a sua pontuação média foi inferior a quatro desvios padrão em relação ao grupo de controle (Mendez, Mendez et al., 1990). O teste provou ser muito sensível para doenças crônicas tanto na demência quanto em pacientes com Parkinson (Jefferson et al., 2006; Levin et al., 1991; Paxton et al., 2007). É recomendado para examinar a disfunção do lobo temporal e, embora possa ter pouco valor preditivo para o desfecho da reabilitação, ele fornece ao médico informações sobre as habilidades visossintéticas do paciente (Greve, et al., 2000; Merten, Völkel \& Dörnberg, 2007) .

Contudo, Merten (2005) destaca questões sobre o uso do VOT e a sua relação com outros tipos de avaliações de habilidades visoespaciais. Em seu estudo com pacientes neurológicos de língua alemã obteve validade de construto por meio de análise fatorial de uma bateria de testes abrangendo as funções visoespaciais, memória, atenção, funções executivas, capacidade de nomeação e vocabulário. Foi obtida a separação em quatro fatores, com substâncial destaque para o fator de capacidade não verbal, que foi interpretada como uma dimensão global de funções cognitivas não verbais, este 
fator é destacado em várias avaliações do processamento visoespacial e da atenção (em particular, o Cubos da WAIS-R, o Teste das Trilhas A e B e as Matrizes Progressivas de Raven). Os outros três fatores foram interpretados como memória, habilidade verbal (vocabulário), além do fator distinto de habilidades de nomeação. $O$ autor citou pesquisas anteriores que apresentaram a separação das habilidades em quatro fatores chamados de: "capacidade cognitiva verbal", "capacidade cognitiva" não-verbal"; "velocidade de processamento de informação" e "memória verbal", com resultados também, de pontuações maiores sobre o fator" habilidade não verbal" para o desempenho do VOT. Além disso, resultados semelhantes foram encontrados em estudos com pacientes de língua inglesa.

Jefferson et al. (2006) realizaram um estudo visando caracterizar clinicamente o desempenho do VOT em participantes com comprometimento cognitivo leve (CCL) e para obter a correlação associada na nomeação e no funcionamento executivo entre os participantes com (CCL) e os controles normais (CN) no VOT. Foram aplicados também os seguintes testes: dois testes para avaliar a função executiva (Trail Making Test, parte B; TMT-B); Associação de Palavra Oral Controlada (COWA) e dois testes de nomeação abreviados, o Teste de Nomeação de Boston (BNT) e Nomeação de Animais. Foram avaliados 222 participantes (CN), $166 \mathrm{com}(\mathrm{CCL})$ e $68 \mathrm{com}$ doença de Alzheimer (DA). Os resultados mostraram que as pontuações no VOT foram diferentes nos três grupos e se distribuíram conforme a proporção esperada pelos autores, (DA $<\mathrm{CCL}<\mathrm{CN}$ ). Estes resultados corroboram os de estudos anteriores de que o VOT é multifatorial, sugerindo que a redução no desempenho deste teste em pacientes CCL pode estar relacionada a deficiências moderadas na recuperação lexical.

Giannakou e Kosmidis (2006) descrevem a importância de se considerar as diferenças culturais nos testes, mesmo para os não verbais. Em seus trabalhos sobre a adequação do Teste de Hooper para a população grega, estudaram um grupo controle e grupos de pacientes psiquiátricos e neurológicos. A amostra total dos participantes saudáveis teve média de 21,3 (DP $=4,74)$. Os itens que tiveram baixa taxa de precisão foram relacionados mais a outras causas do que ao desconhecimento ou a baixa familiaridade da 
população grega em relação às figuras. A análise de regressão revelou que a idade e o nível de educação tiveram influência nos resultados, mas não o gênero.

Alguns estudos de Montgomery e Costa, (1983); Richardson e Marottoli, (1996); Whelihan e Lesher, (1985) citados por Lezak et al. (2012) mostram que o desempenho no VOT não está relacionado de forma significativa ao sexo ou à educação, pelo menos para as idades abaixo de 70 anos, mas apresenta uma relação modesta com a capacidade mental. Quanto à faixa etária, foi encontrada uma queda significativa no desempenho de indivíduos idosos saudáveis mais velhos (entre 76 a 92 anos) comparados a idosos mais jovens (60 a 70 anos). Foi observada uma pontuação média de 23,7 pontos para idosos entre 65 e 85 anos, sugerindo que alguma queda de pontuação pode ser esperada para as idades avançadas.

Os efeitos do envelhecimento neste teste são contraditórios, pois pessoas cognitivamente saudáveis geralmente não falham em mais do que seis itens. As pessoas com sete a 11 erros constituem um grupo que inclui a fronteira entre a perturbação emocional e as doenças cerebrais leves a moderadas, contudo, mais de 11 erros geralmente indicam a possibilidade de patologia cerebral. Portanto, muitos erros também podem ser resultantes de um quadro psiquiátrico, e não de uma condição neuropatológica (Lezak et al., 2012).

Observa-se o interesse crescente em pesquisas sobre o VOT no Brasil, contudo, ainda insuficiente por não apresentar uma adaptação e padronização para nosso país, nem outros dados psicométricos. Uma pesquisa exploratória foi realizada por Tosello (2005) com 50 crianças e adolescentes brasileiros de sete a 18 anos de idade, de ambos os sexos, com nível de escolaridade entre um e 11 anos, que mostrou não haver diferenças significativas no total de acertos e erros entre os sexos nessa faixa etária. Foi constatado que o teste é sensível a diferenças culturais e a atribuição de 1 e 0,5 pontos aos itens em relação ao vocabulário deve ser melhor estudada, sendo sugerido pela autora deste estudo a revisão dos itens 16 (chaleira), 19 (bule) e 25 (cubo).

Alves (2007) propôs mudanças nos desenhos originais do VOT a fim de torná-los mais compatíveis com a realidade brasileira, porém mantendo o 
conteúdo semântico. O teste com a referida mudança foi aplicado a 30 adolescentes do ensino médio de uma escola da rede particular. $O$ desempenho dos participantes no VOT foi comparado com o dos subtestes Vocabulário, Cubos, Armar Objetos e Semelhanças da Escala WISC-III. Foi observada correlação positiva com o subteste Cubos $(r=+0,373$; $p<0,05)$ e negativa com o de Semelhanças ( $r=-0,510 ; p<0,01)$. Os resultados obtidos mostraram que as adaptações realizadas não interferiram na propriedade do VOT de avaliar os domínios visoespaciais da cognição.

A versão do VOT, adaptada como teste de nomeação, foi utilizada por Azambuja (2006), como parte do seu estudo com pacientes portadores da doença de Huntington (doença hereditária degenerativa do cérebro), em função das dificuldades de nomeação que são descritas nestes quadros. Deste modo, a adaptação permitiu à autora discriminar, se os erros estariam relacionados com a percepção visoespacial ou com a nomeação das figuras. Assim, quando o examinando errava na tarefa de organização visual, em que as figuras eram apresentadas em partes separadas, a autora as apresentava novamente, porém montadas para que fossem nomeadas. Caso ainda houvesse erro na nomeação, eram oferecidas pistas semânticas e fonêmicas e, por fim, quatro estímulos gráficos para a identificação da palavra que melhor representasse a figura. A versão adaptada com o teste de nomeação apresentou a mesma estrutura do teste original em relação às figuras não coloridas e o fundo branco no cartão, porém, foi acrescentada uma parte com as figuras organizadas e outra parte com os nomes para o reconhecimento da palavra escrita, relativa à figura apresentada anteriormente.

O objetivo do trabalho de Azambuja foi o de caracterizar as alterações de linguagem na Doença de Huntington $(\mathrm{DH})$ e relacioná-las aos transtornos motores, cognitivos, psiquiátricos e, também, ao tempo de doença. Foram estudadas 26 pessoas, divididas em dois subgrupos em relação à intensidade da doença (leve e moderada) e que foram comparados a dois grupos controle de mesmo gênero, idade e escolaridade. Para a avaliação da linguagem foram aplicados o Teste Boston para Diagnóstico de Afasia, o Teste de Nomeação de Boston e o Teste Token e para o rastreio cognitivo, o teste Mini-exame do Estado Mental, complementado pelos seguintes testes: Teste de Modalidades 
de Dígitos e Símbolos (Smith, 1968), Teste Stroop, Teste Hooper de Organização Visual, Fluência Verbal Semântica, Fonológica e de Verbos (Benton \& Hamsher, 1978). Os sintomas depressivos foram avaliados com a Escala de Depressão de Montgomery e Asberg (1979) e a função motora, com a Escala Unificada para a Investigação da doença de Huntington (Huntington Study Group, 1996). De modo geral, os resultados mostraram alterações nas provas de compreensão e expressão da linguagem oral e gráfica para os dois grupos de doentes. Não houve evidências de prejuízo das representações semânticas. As dificuldades de linguagem se relacionaram ao declínio cognitivo global, especificamente das funções executivas (atenção e memória operacional). Foi obtida correlação positiva com o desempenho em tarefas cognitivas, mas não com as alterações motoras e psiquiátricas da doença, assim como, entre o desempenho da linguagem e a doença.

Em relação ao Teste de Hooper foi observado desempenho inferior nos grupos leve e moderado em relação ao grupo controle. Quando os itens errados foram apresentados montados na tarefa de nomeação, o grupo com DH leve obteve maior número de acertos na nomeação do que o de controle, também, fez mais uso das pistas fonêmicas, porque o número de itens errados pelo grupo de controle era menor. Não houve diferença no total de acertos entre os dois grupos ao considerar o número de respostas espontâneas (para o grupo controle) e com pistas (para o grupo $\mathrm{DH}$ ). Em relação ao grupo com $\mathrm{DH}$ moderada foram encontrados os mesmos resultados, contudo, este grupo fez maior uso de pistas fonêmicas e semânticas em relação ao grupo controle.

Embora o VOT seja um instrumento comumente utilizado na avaliação do processamento visoespacial e pesquisas fundamentadas mostrarem a relação existente entre o hemisfério direito e a função visoespacial, não foi encontrada na literatura consistência nos resultados que indicasse uma associação entre o desempenho no VOT e o hemisfério direito. No entanto isto pode ser devido às falhas dos investigadores em considerar a natureza multifatorial da tarefa. Por exemplo, o desempenho no VOT envolve capacidade de linguagem, ou seja, a designação de um objeto comum, bem como a percepção visual e a síntese. Portanto, um paciente que é capaz de integrar visualmente um objeto com sucesso, pode ainda, responder incorretamente por causa da incapacidade de 
fornecer o nome correto do objeto. Além disso, um paciente com dificuldades de autorregulação pode perseverar em uma resposta incorreta do item anterior para os itens seguintes, ocasionando erros. Assim, os pacientes com integração visoespacial adequada podem mostrar dificuldades no VOT por uma variedade de razões. Isto sugere a necessidade de uma análise qualitativa do desempenho no teste, o que que foi discutido por Hooper (1983), mas não tem sido adequadamente investigado até o momento (Nadler et al., 1996).

[Trecho suprimido na versão online] 
[Trecho suprimido na versão online] 
[Trecho suprimido na versão online] 


\section{OBJETIVOS}

Os objetivos da presente pesquisa de padronização do Teste Hooper de Organização Visual são:

1. Verificar a existência de diferenças em relação às variáveis idade, gênero e escolaridade.

2. Obter normas para o Teste Hooper de Organização Visual para a cidade de São Paulo.

3. Estabelecer a precisão por meio do reteste e pelo método das metades.

4. Determinar a validade pela correlação com os seguintes testes: Figuras Complexas de Rey (Figura A) e os subtestes Cubos e Armar Objetos do WAIS-III.

5. Fazer análise de itens para estabelecer seus níveis de dificuldade para poder reordená-los em função desta variável, bem como verificar a adequação da tradução das respostas corretas aos itens. 


\section{MÉTODO}

\subsection{PESQUISA PILOTO}

Antes da realização da pesquisa foi feita uma versão piloto para verificar se os itens mostrariam um crescimento nas médias de pontos com o aumento da idade e como os participantes responderiam aos itens.

\subsubsection{PARTICIPANTES}

A amostra foi composta por 156 sujeitos de ambos os sexos, com idades entre seis anos e 87 anos. 61 participantes eram do sexo masculino e 95 do feminino, conforme pode ser observado na Tabela 2 e a distribuição de frequência relativa à escolaridade é apresentada na Tabela 3.

Tabela 2. Distribuição de frequência da amostra piloto por idade e sexo

\begin{tabular}{cccc}
\hline \multirow{2}{*}{ Idade } & \multicolumn{3}{c}{ Sexo } \\
\cline { 2 - 4 } & Fem. & Masc. & Total \\
\hline $\mathbf{6 - 7}$ & 7 & 14 & 21 \\
$\mathbf{8 - 9}$ & 13 & 8 & 21 \\
$\mathbf{1 0 - 1 1}$ & 12 & 6 & 18 \\
$\mathbf{1 2 - 1 3}$ & 6 & 4 & 10 \\
$\mathbf{1 4 - 1 5}$ & 3 & 3 & 6 \\
$\mathbf{1 6 - 1 9}$ & 9 & 3 & 12 \\
$\mathbf{2 0 - 2 9}$ & 4 & 7 & 11 \\
$\mathbf{3 0 - 3 9}$ & 11 & 8 & 19 \\
$\mathbf{4 0 - 4 9}$ & 12 & 5 & 17 \\
$\mathbf{5 0 - 5 9}$ & 10 & 3 & 13 \\
$\mathbf{6 0 - 8 9}$ & 8 & & 8 \\
\hline Total & 95 & 61 & 156 \\
\hline
\end{tabular}

O nível escolar variou do ensino fundamental ao superior. A amostra foi oriunda de escolas da rede pública e particular e de clubes recreativos situados 
na cidade de São Paulo. A Tabela 3 mostra a distribuição por idade e escolaridade.

Tabela 3. Distribuição de frequência da amostra por idade e escolaridade

\begin{tabular}{cccccc}
\hline \multirow{2}{*}{ IDADE } & \multicolumn{5}{c}{ ESCOLARIDADE } \\
\cline { 2 - 6 } & $\mathbf{1 a}-\mathbf{4 a}$ & $\mathbf{5 a}-\mathbf{8 a}$ & Médio & Superior & Total \\
\hline $\mathbf{6 - 7}$ & 21 & & & & 21 \\
$\mathbf{8}-\mathbf{9}$ & 21 & & & & 21 \\
$\mathbf{1 0 - 1 1}$ & 4 & 14 & & & 18 \\
$\mathbf{1 2 - 1 3}$ & & 10 & & & 10 \\
$\mathbf{1 4 - 1 5}$ & & 6 & & & 6 \\
$\mathbf{1 6 - 1 9}$ & & 7 & 5 & & 12 \\
$\mathbf{2 0 - 2 9}$ & 2 & 2 & 1 & 6 & 11 \\
$\mathbf{3 0 - 3 9}$ & 7 & 2 & 3 & 7 & 19 \\
$\mathbf{4 0 - 4 9}$ & 1 & 2 & 5 & 9 & 17 \\
$\mathbf{5 0 - 5 9}$ & 5 & 3 & 3 & 2 & 13 \\
$\mathbf{6 0 - 8 9}$ & 2 & 1 & 2 & 3 & 8 \\
\hline Total & $\mathbf{5 9}$ & $\mathbf{5 1}$ & $\mathbf{1 9}$ & $\mathbf{2 7}$ & $\mathbf{1 5 6}$ \\
\hline
\end{tabular}

\subsubsection{MATERIAL}

Foram utilizados os seguintes materiais para o piloto:

1) Um questionário para a triagem elaborado pela autora contendo questões referentes aos dados de identificação e dos critérios de inclusão e de exclusão. Os critérios para a inclusão foram: Nível cognitivo adequado, bom domínio da língua portuguesa para nomear e compreender o conteúdo do instrumento usado, acuidade visual normal ou corrigida. Já para a exclusão foram: Presença de patologia neurológica ou psiquiátrica previamente diagnosticada, deficiência visual ou auditiva; estar em tratamento medicamentoso com drogas ansiolíticas e/ou antidepressivas e uso de drogas ilícitas. 
2) O Termo de Consentimento Livre e Esclarecido para os adultos e para menores de idade, o Termo de Consentimento dos pais ou responsável devidamente assinado.

3) Teste Hooper de Organização Visual (VOT), versão revisada por Western Psychological Services em 1983. Além disso, também foi adaptado para o presente estudo um item exemplo (a figura de um guarda-chuva), visto que na versão original o teste é iniciado pela Figura 1 (peixe).

\subsubsection{PROCEDIMENTO}

Antes de iniciar a pesquisa de campo foi oferecido um treinamento sobre o teste a uma equipe de psicólogos que colaboraram na coleta de dados.

No primeiro contato, o participante recebeu todas as informações necessárias a respeito da pesquisa. Em seguida, respondeu a um questionário contendo questões relativas aos dados pessoais e critérios de inclusão e exclusão. Os participantes receberam o Termo de Consentimento Livre e Esclarecido e, somente após concordarem com todos os quesitos, foram submetidos ao teste. No caso dos participantes menores de idade a assinatura foi dos pais ou responsáveis.

A aplicação do teste nas escolas se deu na sala de leitura fora do horário de uso dos alunos. Quanto aos universitários foi reservada a sala de estudos. Os participantes do clube recreativo preferiram realizar o teste após as suas atividades e, sendo assim, fizeram filas ao lado de fora do salão e foram sendo chamados individualmente. Todos os locais de aplicação tinham boa iluminação, ambiente arejado, silencioso e mobília adequada para o conforto do participante e do aplicador.

O teste foi aplicado individualmente, seguindo todas as instruções padronizadas de aplicação descritas no manual. O bloco contendo as trinta figuras foi colocado em frente ao examinando e foi dada a instrução de acordo com o manual, exceto pela inclusão do exemplo do guarda-chuva. Foi exibido o bloco com as figuras apresentadas fragmentadas e aplicado todos os itens. Desse modo, o participante recebeu um ponto para o acerto, meio ponto para as respostas aproximadas, e zero em caso de erro. 


\subsection{PESQUISA DE PADRONIZAÇÃO}

\subsubsection{PARTICIPANTES}

A amostra da pesquisa de padronização foi composta por 969 adultos de ambos os sexos, com idades entre 18 e 82 anos, subdivididos nas seguintes faixas etárias: 18 a 20, de 21 a 30, de 31 a 40 anos, de 41 a 50 anos, de 51 a 60 anos, de 61 a 82 anos; sendo 518 (53,5\%) mulheres e 451 (46,5\%) homens. A escolaridade foi representada por 284 (29,3\%) participantes com nível de ensino fundamental, 338 (34,9\%), de ensino médio e $347(35,8 \%)$ de ensino superior.

As Tabelas 4, 5 e 6 apresentam os dados descritivos da amostra em função da escolaridade, sexo e idade.

Tabela 4. Distribuição da amostra em função da escolaridade e do sexo

\begin{tabular}{lcccccc}
\hline \multirow{2}{*}{ Escolaridade } & \multicolumn{2}{c}{ Feminino } & \multicolumn{2}{c}{ Masculino } & \multicolumn{2}{c}{ Total } \\
& $\mathbf{N}$ & $\mathbf{\%}$ & $\mathbf{N}$ & $\mathbf{\%}$ & $\mathbf{N}$ & $\mathbf{\%}$ \\
\hline Fundamental & 149 & 28,8 & 135 & 29,9 & 284 & 29,3 \\
Médio & 172 & 33,2 & 166 & 36,8 & 338 & 34,9 \\
Superior & 197 & 38,0 & 150 & 33,3 & 347 & 35,8 \\
\hline TOTAL & $\mathbf{5 1 8}$ & $\mathbf{5 3 , 5}$ & $\mathbf{4 5 1}$ & $\mathbf{4 6 , 5}$ & $\mathbf{9 6 9}$ & $\mathbf{1 0 0 , 0}$ \\
\hline
\end{tabular}

A Tabela 4 mostra que, tanto na amostra total quanto na dividida por gênero, os três níveis de escolaridade ficaram distribuídos de forma balanceada, embora no nível fundamental ela seja um pouco menor. 
Tabela 5. Distribuição da amostra em função da faixa etária e do sexo

\begin{tabular}{lcccccc}
\hline \multirow{2}{*}{ Faixa etária } & \multicolumn{2}{c}{ Feminino } & \multicolumn{2}{c}{ Masculino } & \multicolumn{2}{c}{ Total } \\
& $\mathbf{N}$ & $\%$ & $\mathbf{N}$ & $\mathbf{\%}$ & $\mathbf{N}$ & $\%$ \\
\hline $\mathbf{1 8}$ a $\mathbf{2 0}$ & 67 & 12,9 & 63 & 14,0 & 130 & 13,4 \\
$\mathbf{2 1}$ a $\mathbf{3 0}$ & 133 & 25,7 & 123 & 27,2 & 256 & 26,4 \\
$\mathbf{3 1}$ a $\mathbf{4 0}$ & 117 & 22,6 & 73 & 16,2 & 190 & 19,6 \\
$\mathbf{4 1}$ a $\mathbf{5 0}$ & 97 & 18,7 & 63 & 14,0 & 160 & 16,5 \\
$\mathbf{5 1}$ a $\mathbf{6 0}$ & 60 & 11,6 & 61 & 13,5 & 121 & 12,5 \\
$\mathbf{6 1}$ ou mais & 44 & 8,5 & 68 & 15,1 & 112 & 11,6 \\
TOTAL & $\mathbf{5 1 8}$ & $\mathbf{5 3 , 5}$ & $\mathbf{4 5 1}$ & $\mathbf{4 6 , 5}$ & $\mathbf{9 6 9}$ & $\mathbf{1 0 0 , 0}$
\end{tabular}

Em relação à distribuição da faixa etária, observa-se que a maior concentração de participantes ficou na faixa de 21 a 30 anos. Essa característica é observada na amostra total, bem como em cada grupo de gênero. Além disso, a distribuição das idades ficou bastante balanceada em cada faixa quando considerada a amostra total. Já em relação ao sexo, apenas a faixa de 61 anos ou mais ficou com uma frequência menor de mulheres.

A Tabela 6 mostra a distribuição de frequência da amostra de padronização em relação à escolaridade, sexo e idade. 
Tabela 6. Distribuição de frequência por escolaridade, sexo e faixa etária

\begin{tabular}{|c|c|c|c|c|c|c|c|c|}
\hline \multirow{2}{*}{ Escolar } & \multirow{2}{*}{ Sexo } & \multicolumn{6}{|c|}{ Faixa Etária } & \multirow{2}{*}{ Total } \\
\hline & & 18 a 20 & 21 a 30 & 31 a 40 & 41 a 50 & 51 a 60 & $\geq 61$ & \\
\hline \multirow{3}{*}{ Fundam. } & Fem & 20 & 39 & 23 & 21 & 18 & 28 & 149 \\
\hline & Masc & 20 & 40 & 15 & 17 & 20 & 23 & 135 \\
\hline & Total & 40 & 79 & 38 & 38 & 38 & 51 & 284 \\
\hline \multirow{3}{*}{ Médio } & Fem & 23 & 41 & 39 & 40 & 19 & 10 & 172 \\
\hline & Masc & 20 & 46 & 35 & 24 & 21 & 20 & 166 \\
\hline & Total & 43 & 87 & 74 & 64 & 40 & 30 & 338 \\
\hline \multirow{3}{*}{ Superior } & Fem & 24 & 53 & 55 & 36 & 23 & 6 & 197 \\
\hline & Masc & 23 & 37 & 23 & 22 & 20 & 25 & 150 \\
\hline & Total & 47 & 90 & 78 & 58 & 43 & 31 & 347 \\
\hline \multicolumn{2}{|c|}{ TOTAL } & 130 & 256 & 190 & 160 & 121 & 112 & 969 \\
\hline
\end{tabular}

Observa-se que a escolaridade ficou distribuída de forma balanceada, tanto quanto se considera a amostra total, como em relação ao sexo.

\subsubsection{MATERIAL}

Um questionário (Apêndice A) para a triagem foi elaborado pela autora contendo questões referentes aos dados de identificação e dos critérios de inclusão e de exclusão. Os critérios de inclusão foram: nível cognitivo adequado, bom domínio da língua portuguesa para nomear e compreender o conteúdo do instrumento usado; acuidade visual normal ou corrigida. Para exclusão foram: Presença de patologia neurológica ou psiquiátrica previamente diagnosticada, deficiência visual ou auditiva; estar em tratamento medicamentoso com drogas ansiolíticas e/ou antidepressivas, fazer uso de drogas ilícitas. Também houve um Termo de Consentimento Livre e Esclarecido (Apêndice B) assinado pelos participantes após leitura e esclarecimento sobre todos os dados pertinentes a pesquisa como também em relação ao pesquisador.

Para a padronização foi aplicado o Teste Hooper de Organização Visual (VOT), versão revisada por Western Psychological Services de 1983. 


\subsubsection{PROCEDIMENTO}

No primeiro contato o participante recebeu todas as informações necessárias a respeito da pesquisa. Em seguida, respondeu a um questionário contendo questões relativas aos dados pessoais e critérios de inclusão e exclusão (Apêndice A). Os participantes selecionados receberam o Termo de Consentimento Livre e Esclarecido (Apêndice B) e, somente após concordarem com todos os quesitos foram submetidos ao teste. No local de aplicação houve iluminação e ventilação adequada, ambiente silencioso e mobília apropriada ao conforto do participante e do aplicador.

\section{[Trecho suprimido na versão online]}

As análises estatísticas foram realizadas com o auxílio do programa estatístico SPSS versão 19.0 (StatisticalPackage for the Social Science). Foram calculadas frequências, médias e desvios-padrão para caracterização da amostra; foi estabelecido o nível de dificuldade dos itens para poder reordená-los em função desta variável, por meio do cálculo da porcentagem de acertos e da correlação item-total e, por fim, verificou-se a existência de diferenças em relação às variáveis idade, sexo e escolaridade por meio da Análise de Variância ANOVA e do teste de Tukey. 


\section{PESQUISA DE VALIDADE E PRECISÃO}

\subsection{PARTICIPANTES}

A amostra do reteste foi composta por 69 adultos, que também foram incluídos na amostra geral de normatização do Teste Hooper. As idades variaram entre 18 e 67 anos (M=35,30; $D P=15,28)$. Quanto à escolaridade, todos tinham entre o ensino fundamental e superior. A maioria $(53,6 \%)$ era do sexo masculino. A Tabela 7 mostra a distribuição em função do sexo e da escolaridade da amostra de reteste.

Tabela 7. Distribuição da amostra do reteste por escolaridade e sexo

\begin{tabular}{lcccccc}
\hline \multirow{2}{*}{ Escolaridade } & Feminino & $\%$ & Masculino & $\%$ & Total & $\%$ \\
\cline { 2 - 7 } & $\mathbf{N}$ & $\%$ & $\mathbf{N}$ & $\%$ & $\mathbf{N}$ & $\%$ \\
\hline Fundamental & 10 & 31,3 & 13 & 35,1 & 23 & 33,3 \\
Médio & 8 & 25,0 & 14 & 37,9 & 22 & 31,9 \\
Superior & 14 & 43,7 & 10 & 27,0 & 24 & 34,8 \\
\hline Total & $\mathbf{3 2}$ & $\mathbf{4 6 , 4}$ & $\mathbf{3 7}$ & $\mathbf{5 3 , 6}$ & $\mathbf{6 9}$ & $\mathbf{1 0 0 , 0}$ \\
\hline
\end{tabular}

Para a precisão pelo método das metades foi usada a amostra total para a qual foram obtidas as normas.

A amostra para a validade foi constituída por 54 pessoas, que também fizeram parte do grupo de normatização desta pesquisa. As idades variaram entre 18 e 78 anos $(M=39,67 ; D P=15,67)$ e a escolaridade, entre o ensino fundamental e superior. A maioria $(53,7 \%)$ eram mulheres e os demais $(46,3)$ homens, cuja distribuição é mostrada na Tabela 8. Observa-se que, na amostra de validade, a maior parte tinha o ensino superior. 
Tabela 8. Distribuição da amostra de validade por sexo e escolaridade

\begin{tabular}{lcccccc}
\hline \multirow{2}{*}{ Escolaridade } & \multicolumn{2}{c}{ Feminino } & \multicolumn{2}{c}{ Masculino } & \multicolumn{2}{c}{ Total } \\
& $\mathbf{N}$ & \% & N & \% & N & $\%$ \\
\hline Fundamental & 5 & 17,2 & 3 & 12,0 & 8 & 14,8 \\
Médio & 9 & 31,0 & 11 & 44,0 & 20 & 37,0 \\
Superior & 15 & 51,8 & 11 & 44,0 & 26 & 48,2 \\
\hline TOTAL & $\mathbf{2 9}$ & $\mathbf{5 3 , 7}$ & $\mathbf{2 5}$ & $\mathbf{4 6 , 3}$ & $\mathbf{5 4}$ & $\mathbf{1 0 0 , 0}$ \\
\hline
\end{tabular}

15.2. MATERIAL

[Trecho suprimido na versão online] 


\subsection{PROCEDIMENTO}

Para obtenção da precisão, o Teste de Hooper foi aplicado e retestado depois de um intervalo entre 30 e 70 dias. Em relação à precisão das metades, o teste foi subdividido em itens pares e ímpares e foram correlacionados os totais de cada parte e corrigidos pela fórmula de Spearman-Brown.

Para o estabelecimento da validade foram aplicados nesta ordem os seguintes testes: 1) Teste Hooper de Organização Visual; 2) Figuras Complexas de Rey (Forma A); 3) Cubos; e 4) Armar Objetos.

O Teste de Organização Visual Hooper foi aplicado e pontuado conforme as instruções do manual, assim como os demais testes.

O tratamento estatístico para a precisão pelo reteste foi obtido pela correlação de Pearson para a pontuação total e para cada um dos itens para verificar se estes apresentavam itens com baixa precisão. Também foi feito 0 teste $t$ para verificar a existência de diferenças entre os resultados das duas aplicações para o total de pontos.

Para a precisão das metades os itens foram divididos em pares e ímpares, e foi calculada a correlação de Pearson para os totais parciais e o resultado foi corrigido pela fórmula de Spearman-Brown.

Para a validade os pontos brutos do Hooper foram correlacionados com os pontos brutos dos três testes aplicados e com os pontos ponderados dos subtestes do WAIS-III. 
[Trecho suprimido na versão online] 
16. RESULTADOS

16.1 .RESULTADOS DA PESQUISA PILOTO

[Trecho suprimido na versão online] 
[Trecho suprimido na versão online] 
[Trecho suprimido na versão online] 


\section{[Trecho suprimido na versão online]}

Tabela 11. Análise de variância do total de pontos por idade, sexo e escolaridade

\begin{tabular}{lccc}
\hline Variável & GL & F & Sig. \\
\hline Modelo Corrigido & $\mathbf{4 3}$ & $\mathbf{4 , 1 2 1}$ & 0,000 \\
\cline { 2 - 4 } Interseção & $\mathbf{1}$ & $\mathbf{2 9 6 8 , 7 7 5}$ & 0,000 \\
Idade & $\mathbf{1 0}$ & $\mathbf{3 , 0 0 2}$ & $\mathbf{0 , 0 0 2}$ \\
\cline { 2 - 4 } Sexo & $\mathbf{1}$ & $\mathbf{1 , 1 6 5}$ & $\mathbf{0 , 2 8 3}$ \\
Escolaridade & $\mathbf{3}$ & $\mathbf{1 1 , 8 7 6}$ & $\mathbf{0 , 0 0 0}$ \\
Idade e Sexo & 9 & 0,545 & 0,838 \\
Idade e Escolaridade & 14 & 0,965 & 0,494 \\
Sexo e Escolaridade & 3 & 0,879 & 0,454 \\
Idade, Sexo e Escolaridade & 3 & 1,878 & 0,137 \\
Erro & 112 & & \\
Total & 156 & & \\
Corrigido Total & 155 & & \\
\hline
\end{tabular}

A Tabela 11 mostra os resultados da Análise de Variância, cujo objetivo foi determinar as diferenças entre médias em relação à idade, sexo e escolaridade. Os resultados mostraram diferenças estatisticamente significantes entre as idades e os níveis de escolaridade, mas não entre os sexos. Nas Tabelas 12 e 13 são apresentados os Testes Post Hoc de Tukey para determinar, respectivamente, entre que faixas de idade e níveis de escolaridade existem diferenças estatisticamente significantes. 
Para facilitar a descrição dos resultados, as faixas serão denominadas pela primeira idade dos intervalos. Os resultados mostraram que as faixas etárias se dividiram em três subconjuntos, cujas médias diferem estatisticamente entre si, mas não dentro de cada subconjunto. No primeiro subconjunto se agruparam as médias de 6, 8, 30 e 50 anos. Não ocorreram diferenças entre 6 e 8 anos, que tiveram médias muito semelhantes. No segundo subconjunto ficaram as médias de 8, 10, 12, 16 anos, além de 30 e 50 anos, que também estavam no primeiro subconjunto. No terceiro subconjunto estiveram as médias de todas as faixas, exceto 6 e 8 anos.

Quanto à escolaridade, as médias também se dividiram em três subconjuntos, um para cada um dos níveis do ensino fundamental e um terceiro que englobou os dados do Ensino Médio e Superior que não diferiram entre si. A Tabela 14 apresenta as porcentagens de acerto e as correlações item-total para cada item.

[Trecho suprimido na versão online]

[Trecho suprimido na versão online] 
[Trecho suprimido na versão online] 
[Trecho suprimido na versão online]

\subsection{RESULTADOS DA PESQUISA DE PADRONIZAÇÃO}

A Figura 13 mostra o histograma do total de pontos para a amostra total, em que é possível observar que a distribuição de frequência é bastante próxima da curva normal. A Tabela 15 mostra as estatísticas descritivas para 0 total da amostra.

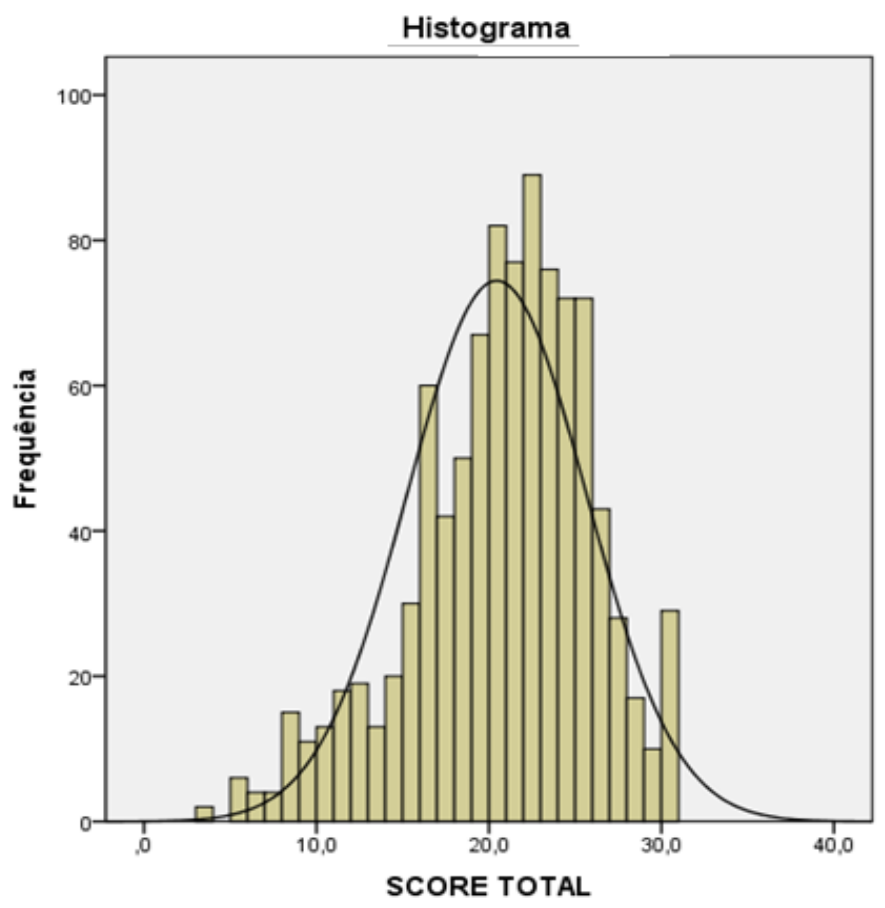

Figura 13. Histograma do total de pontos da amostra de padronização 


\subsubsection{ANÁLISE DE VARIÂNCIA}

Para determinar a existência de diferenças entre as médias do total de pontos do Hooper em função do sexo, idade e escolaridade foi realizada uma Análise de Variância, levando em conta essas três variáveis que são apresentadas na Tabela 15.Os resultados dessa análise indicaram a existência de diferenças, com nível de significância menor do que 0,005, entre os sexos, as faixas etárias e os níveis de escolaridade, bem como na interação entre sexo e escolaridade, sexo e idade, e escolaridade e idade e, inclusive, na interação entre essas três variáveis.

[Trecho suprimido na versão online] 
Tabela 15. Análise de Variância por sexo, idade e escolaridade

\begin{tabular}{lccc}
\hline Fonte & GI & F & Sig. \\
\hline Modelo Corrigido & 35 & $\mathbf{1 5 , 1 8 0}$ & $\mathbf{0 , 0 0 0}$ \\
\hline Sexo & 1 & $\mathbf{1 2 , 0 7 9}$ & $\mathbf{0 , 0 0 1}$ \\
\hline Escolaridade & 2 & $\mathbf{1 3 6 , 3 0 6}$ & $\mathbf{0 , 0 0 0}$ \\
\hline Idade & 5 & $\mathbf{1 3 , 6 0 2}$ & $\mathbf{0 , 0 0 0}$ \\
\hline Sexo * Escolaridade & 2 & $\mathbf{7 , 3 9 7}$ & $\mathbf{0 , 0 0 1}$ \\
\hline Sexo * Idade & 5 & $\mathbf{2 , 9 3 4}$ & $\mathbf{0 , 0 1 2}$ \\
\hline Escolaridade * Idade & 10 & $\mathbf{6 , 6 4 2}$ & $\mathbf{0 , 0 0 0}$ \\
\hline Sexo * Escolaridade * Idade & 10 & $\mathbf{3 , 5 1 6}$ & $\mathbf{0 , 0 0 0}$ \\
\hline
\end{tabular}

[Trecho suprimido na versão online]

Em relação à escolaridade, as médias se dividiram em três subconjuntos, um para cada nível de escolaridade, indicando diferenças nas médias entre os três níveis (fundamental, médio e superior). Pode ser observado que as médias de pontos crescem conforme aumenta a escolaridade, razão pela qual devem ser estabelecidas normas separadas para cada nível de escolaridade. 
Considerando a idade é possível observar que os resultados se separaram em quatro subconjuntos, que podem ser descritos da seguinte forma:

1) A faixa etária com idade igual ou superior a 61 não diferiu do grupo de 51 a 60, mas difere de todas as demais.

2) A faixa etária de 51 a 60 anos não diferiu da de 61 anos ou mais e da de 41 a 50 anos.

3) A faixa etária de 41 a 50 anos diferiu do grupo de 61 ou mais e da de 18 a 20 anos.

4) As faixas entre 21 e 50 anos mostraram diferenças significantes em relação às de 51 anos ou mais.

5) A faixa de 18 a 20 anos diferiu de 41 anos ou mais.

Dessa forma, devem ser estabelecidas normas considerando essas divisões, mas pode ser observada uma tendência de diminuição das médias com o aumento da idade.

\section{[Trecho suprimido na versão online]}

Pela Tabela 18 pode-se constatar que o único nível de escolaridade que obteve diferença significante entre os sexos foi a relativa ao ensino superior, em que os homens tiveram médias mais altas do que as mulheres, com uma diferença de 2,7 pontos. No ensino médio a diferença foi próxima do nível de significância, mas não atingiu, mostrando uma tendência para diferença a favor dos homens, mas a diferença foi de apenas 1 ponto. 


\section{[Trecho suprimido na versão online]}

Em relação à faixa etária, somente foi encontrada diferença significante entre as médias dos dois sexos na faixa de 61 anos ou mais, em que os homens também tiveram resultados mais altos, com uma diferença de 4,6 pontos. 
[Trecho suprimido na versão online]

16.2.2 NORMAS

[Trecho suprimido na versão online] 
[Trecho suprimido na versão online]

[Trecho suprimido na versão online] 
[Trecho suprimido na versão online]

16.2.3. PRECISÃO PELO RETESTE

A Tabela 23 mostra os resultados relativos à precisão pelo reteste, tanto em relação à correlação quanto pela diferença de médias entre as duas aplicações. 


\section{[Trecho suprimido na versão online]}

A correlação obtida entre o teste e o reteste foi de 0,897 , mostrando alto grau de precisão do teste Hooper. De acordo com Guilford (1950), essa correlação é alta e confirma a fidedignidade do instrumento. Foi observado também que houve diferença estatisticamente significante entre a média do total de pontos entre o teste e o reteste, como mostrou o resultado do teste $t$, com aumento de 0,66 pontos na segunda aplicação.

A Tabela 24 mostra as correlações teste-reteste para cada item.

\section{[Trecho suprimido na versão online]}

As correlações entre teste e reteste foram estatisticamente significantes para todos os itens, com variação entre 0,315 e 0,880. Não foi possível calcular a correlação para os itens de 1 a 4, porque uma das variáveis foi constante. 0 resultado indicou que o aumento de pontos no reteste indica um efeito de aprendizagem. 


\section{[Trecho suprimido na versão online]}

\subsubsection{PRECISÃO DAS METADES}

Segundo Anastasi (1977), o cálculo de precisão é utilizado para medir a consistência interna do instrumento ao se dividir os itens em metades equivalentes e correlacionar os totais de pontos de cada metade. Como essa correlação se refere apenas à metade do teste é necessário fazer a correção aplicando a fórmula de Spearman Brown. Neste caso, o teste foi dividido em itens pares e ímpares.

A correlação entre as duas metades foi de 0,793, significante a 0,01 que corrigida pela fórmula de Spearman-Brown, corresponde a 0,884. Este resultado constitui uma precisão satisfatória do Teste Hooper, segundo o critério adotado por Guilford (1950).

\subsubsection{VALIDADE}

A validade de critério simultânea foi obtida pela correlação entre outros testes que avaliam a organização perceptiva visual, o Teste da Figura Complexa de Rey e os subtestes Cubos e Armar Objetos do WAIS-III. Para esse objetivo foi utilizado o total de pontos brutos do Hooper, que foi correlacionado com os pontos brutos dos demais testes e com os pontos ponderados dos subtestes do WAIS-III, que levam em conta a idade. As correlações obtidas são apresentadas nas Tabela 25 e 26. 
Tabela 25. Correlações entre os pontos brutos do Hooper e os demais testes

\begin{tabular}{ll}
\hline \multicolumn{1}{c}{ Testes } & Hooper \\
\hline Figuras de Rey (P. bruto) & $\mathbf{0 , 3 0 2 ^ { * }}$ \\
\hline Cubos (P. bruto) & $\mathbf{0 , 5 4 3 ^ { * * }}$ \\
\hline Cubos (P. ponderado) & $\mathbf{0 , 4 7 0 ^ { \star * }}$ \\
\hline Armar Objetos (P. bruto) & $\mathbf{0 , 4 8 7 ^ { * * }}$ \\
\hline Armar Objetos (P. ponderado) & $\mathbf{0 , 4 1 6 ^ { \star * }}$ \\
${ }^{* \star} p \leq 0,01 ;{ }^{*} p \leq 0,05$ &
\end{tabular}

Os resultados mostram que todas as correlações foram estatisticamente significantes, sendo que a mais baixa foi obtida com o Teste da Figura Complexa de Rey $(0,302)$, cuja tarefa é a cópia de uma figura. A maior foi obtida com o subteste Cubos do WAIS-III $(0,543)$, seguida da do Armar Objetos $(0,487)$. Deve-se lembrar que esses subtestes apresentam uma tarefa de construção de uma figura a partir de suas partes, assemelhando-se mais à tarefa do Hooper. No caso dos subtestes do WAIS-III, é possível observar ainda, que as correlações com os pontos brutos foram maiores do que com as ponderadas, provavelmente porque no Hooper também foram usados os pontos brutos. Com exceção da correlação com o Teste de Rey, todas as outras foram correlações moderadas. 
Tabela 26. Correlações entre os demais testes $(\mathrm{N}=54)$

\begin{tabular}{cccccc} 
Testes & & Rey & $\begin{array}{c}\text { Cubos } \\
\text { Brutos }\end{array}$ & $\begin{array}{l}\text { Cubos } \\
\text { Pond. }\end{array}$ & $\begin{array}{c}\text { Armar Ob. } \\
\text { Brutos }\end{array}$ \\
$\begin{array}{ccccc}\text { Cubos } \\
\text { Brutos }\end{array}$ & R & $\mathbf{0 , 3 4 9 ^ { * * }}$ & & & \\
Cubos & $\mathrm{R}$ & $\mathbf{0 , 3 2 7 ^ { * }}$ & $\mathbf{0 , 9 0 0 ^ { * * }}$ & & \\
Pond. & Sig. & 0,016 & 0,000 & & \\
\hline Armar Ob. & $\mathrm{R}$ & 0,187 & $\mathbf{0 , 6 2 7 ^ { * * }}$ & $\mathbf{0 , 4 7 3 ^ { * * }}$ & \\
Brutos & Sig. & 0,176 & 0,000 & 0,000 & \\
Armar Ob. & $\mathrm{R}$ & 0,159 & $\mathbf{0 , 4 4 6}$ & $\mathbf{0 , 4 0 1}$ & $\mathbf{0 , 8 1 0}$ \\
Pond. & Sig. & 0,251 & 0,001 & 0,003 & 0,000 \\
\hline
\end{tabular}

[Trecho suprimido na versão online]

[Trecho suprimido na versão online] 
[Trecho suprimido na versão online]

[Trecho suprimido na versão online] 
[Trecho suprimido na versão online]

[Trecho suprimido na versão online] 
[Trecho suprimido na versão online]

[Trecho suprimido na versão online] 


\section{DISCUSSÃO}

O principal objetivo desta pesquisa foi realizar estudos psicométricos de padronização, validade e precisão do Teste Hooper para a cidade de São Paulo, constituindo o primeiro estudo brasileiro com esse objetivo. Diferentemente dos estudos apresentados no manual por Hooper (1983), este foi realizado com uma amostra ampla, pois a usada por esse autor para obtenção das normas em 1948 foi composta por apenas 224 participantes, sendo que os estudantes do ensino médio tiveram uma média de 25,43 , os universitários 25,64 e os idosos 18,57 . Hooper propôs a interpretação dos resultados do teste em três tipos de escores:

1) Pontuação bruta total, que varia de 1 a 30 pontos e é referente ao total de respostas corretas, sendo que o autor emprega pontos de corte para indicar a classificação do grau do prejuízo.

2) Pontos brutos corrigidos, que permitem ajustar a pontuação levando em conta a idade e o nível educacional. Neste caso também sugere pontos de corte.

3) Nota T, que é um resultado padrão com uma média de 50 e desvio padrão de 10 , mas Hooper inverteu a direção do $T$, de modo que um valor maior indique maior patologia. Os valores críticos nesse caso são os que se encontram a um ou dois desvios padrão da média, equivalentes à Notas T $60 \mathrm{a}$ 70 ou maiores.

O outro estudo relatado no manual foi o de Mason e Ganzler, o qual contou com apenas 231 participantes, a maioria constituída de pacientes pulmonares ou internados para cirurgia geral em um hospital. A média da pontuação bruta dessa amostra foi de 25,71 (DP = 4,78). Hooper (1983) apresentou como normas no seu manual as tabelas de Nota $T$ obtidas por Mason e Ganzler, porque considerou que elas eram baseadas em uma amostra mais representativa, possuía uma descrição mais detalhada dos procedimentos de inclusão na amostra e foram coletadas 15 anos depois da sua padronização de 1948.

Comparando as médias da presente pesquisa com as de Hooper e de Mason e Ganzler, pode-se perceber que a média para a amostra total $(20,45)$ 
foi bem mais baixa que as relatadas por esses autores, o que pode ser devido ao tamanho muito maior da amostra desta pesquisa, que procurou incluir pessoas de todos os níveis de escolaridade, dos dois sexos e das faixas etárias em proporção aproximadamente igual, o que a torna mais representativa. A pontuação bruta da amostra total da padronização mostrou uma distribuição de frequência semelhante à curva normal. Na pesquisa de Hooper não foram incluídas pessoas com escolaridade mais baixa, bem como Mason e Ganzler só estudaram homens, sendo a maioria constituída por pacientes internados em um hospital, enquanto a presente amostra foi constituída por pessoas supostamente normais e que não faziam parte de grupos com patologias conhecidas. Também é importante considerar as diferenças culturais nas pontuações dos testes, pois Giannakou e Kosmidis (2006) investigando a adequação do Teste de Hooper para a população grega, obtiveram média de 21,3 (DP $=4,74)$ para os participantes saudáveis, resultado que é bem próximo ao desta pesquisa.

Uma diferença deste estudo em relação aos dois primeiros comentados se refere ao fato de que as normas foram apresentadas em percentil por se tratar de um tipo de norma muito utilizada nos testes publicados no Brasil e também por ser de conhecimento da maioria dos psicólogos. Muitos poucos testes empregam normas em Nota T em nosso país, fazendo com que os psicólogos fiquem pouco familiarizados com elas. Uma outra diferença é que os resultados não foram invertidos, sendo que os escores mais altos indicam uma organização perceptiva melhor, enquanto os resultados baixos se referem a dificuldades nessa área.

Para o estabelecimento das normas foi investigada, inicialmente, a existência de diferenças em relação às variáveis idade, sexo e escolaridade, de modo a verificar a necessidade de tabelas que levassem em conta essas variáveis. No manual de Hooper as tabelas normativas apresentadas possibilitam a transformação dos pontos brutos em pontos brutos corrigidos pela idade e nível de escolaridade que, depois, são transformados em notas T por uma tabela única. Não foram estabelecidos pontos de corte, porque foram utilizadas amostras clínicas. 
Foram encontradas diferenças significantes de médias entre as faixas etárias, os níveis de escolaridade e os sexos, razão pela qual foram apresentadas tabelas normativas em percentis considerando essas variáveis. Em relação à escolaridade os resultados indicaram um aumento das médias com a progressão da escolaridade. Na pesquisa de Hooper podem ser constatadas médias praticamente iguais entre os estudantes de ensino médio e os universitários. Na tabela de conversão para pontos brutos corrigidos em relação a idade e escolaridade, observa-se também que o aumento dos anos de estudos indica resultados mais patológicos, ou seja, os pontos corrigidos diminuem.

Mesulam (2000) também observou que o nível educacional pode influenciar no desempenho do VOT, que aumenta no mesmo sentido que a escolaridade. Giannakou e Kosmidis (2006), empregando análise de regressão, também encontraram influência da idade e do nível educacional nos resultados do VOT, mas não do sexo. Contudo Lezak et al. (2012), ao comentarem algumas pesquisas a esse respeito, afirmam que o desempenho no VOT não apresentou relação significativa com o sexo ou a educação para as idades abaixo de 70 anos, mas mostrou uma relação modesta com a capacidade mental.

Já Mason e Ganzler (citados por Hooper, 1983) obtiveram uma correlação de 0,33 entre o nível educacional e as pontuações do VOT, porém, quando foi controlada a inteligência, a correlação baixou para 0,06 , mostrando que a variância comum à escolaridade e à pontuação no VOT pode ser atribuída ao fator inteligência, pois a correlação entre o nível educacional e o teste de Vocabulário de Shipley, usado para avaliar a inteligência, foi de 0,40. Contudo, Hooper concluiu que o nível de escolaridade é muito mais fácil de conseguir do que uma estimativa da inteligência, tornando-se mais fácil considerar a escolaridade.

Boyd (1981) também obteve correlação entre o VOT e o Teste Peabody, sugerindo que a inteligência influencia o desempenho no teste. Tamkin e Jacobsen (1984), por meio de uma análise de regressão múltipla, constataram que apenas a idade e o QI foram responsáveis por uma quantidade significativa de variância nos escores do VOT e, por isso, defendem o uso de normas 
relacionadas à idade e ao QI. De qualquer modo, é importante considerar o nível de inteligência e a escolaridade ao se analisar o desempenho no VOT, pois indivíduos com maior escolaridade tendem a possuir maiores recursos lexicais.

Como a presente pesquisa não controlou o nível de inteligência da amostra, não se pode tirar conclusões a respeito dessa variável, mas deve-se considerar, da mesma maneira que Hooper (1983), que o nível educacional pode ser usado como uma variável relacionada ao nível intelectual. Hooper afirma que a relação entre a pontuação no VOT e a idade é curvilínea. Nas idades até 18 anos, a correlação é levemente positiva, mas não significante. Nos adultos jovens e na faixa de idade média de adultos praticamente não há relação entre a idade e o total de pontos. Porém, com o processo de envelhecimento, a correlação vai se tornando maior e negativa, o que provavelmente se relaciona ao declínio em certas funções cognitivas causadas pelo envelhecimento.

Em relação à idade, pode-se observar pela Tabela 20 que nesta pesquisa foi encontrada uma tendência de diminuição das médias à medida em que a idade aumenta, embora a diferença entre a maior e a menor médias seja de apenas 3,5 pontos. Comparando-se as médias dos grupos com idades a partir de 51 é possível perceber que as médias $(18,86$ e 18,35) são bastante próximas à obtida por Hooper (18,57). Mertem e Beal (1999) encontraram resultado semelhante em 320 pacientes neurológicos, com idade média de 51,3 anos, que obtiveram pontuação média de 18,8 (DP = 6,2). Nesta pesquisa decidiu-se estabelecer normas para todas as faixas etárias consideradas, embora as diferenças sejam pequenas entre 21 e 50 anos.

Lezak et al. (2012) relatam que a literatura é controversa quanto aos dados sobre o efeito do envelhecimento no teste, citando alguns estudos como o de Whelihan e Lesher (1985), em que os autores destacam uma queda significativa no desempenho de idosos normais com idades entre 76-92 anos, quando comparados a um grupo entre 60 a 70 anos. Montgomery e Costa (1983) encontraram pontuação média de 23,7 para uma grande amostra de idosos com idades entre 65-85, sugerindo que uma queda no desempenho pode ocorrer com o aumento da idade. Outras investigações com idosos dos 
dois sexos, relacionando idade e educação, mostraram pequena diminuição de pontos para as faixas entre 76 a 80 e 81 a 91 anos com menos de 12 anos de estudo, em relação a idosos mais jovens com média de 17,9 e com 12 anos de estudo ou mais, indicando que estes últimos têm alta probabilidade de comprometimento. Mesulam (2000) destaca para os adultos jovens uma média de 25 pontos e para os com mais de 65 anos de 22 pontos, que pode ser considerada normal.

Em relação à existência de diferenças entre os sexos no funcionamento cognitivo, Hooper (1983) lembra que esta tem sido encontrada frequentemente na literatura, mas os resultados são controvertidos. Cita as conclusões de Maccoby e Jacklin (1974) de que os homens costumam ser melhores em tarefas quantitativas e visoespaciais, enquanto as mulheres têm mais facilidade em tarefas verbais, o que pode indicar a necessidade de considerar essas diferenças no desempenho cognitivo. No entanto o VOT avalia tanto as capacidades verbais como as visoespaciais. Em uma pesquisa de 1958, Hooper não encontrou diferenças, mas lembra que não controlou as variáveis sexo, idade e educação. Apresenta os resultados de um segundo estudo realizado por Wentworth-Rohr et al. (1974), em que nos três grupos estudados não foram encontradas diferenças em relação a essa variável. Resultado semelhante foi obtido por Giannakou e Kosmidis (2006).

Nesta pesquisa somente foi observada diferença entre os sexos para o nível de escolaridade superior e na faixa de 61 anos ou mais em que os homens tiveram médias mais altas. Esse resultado provavelmente está relacionado ao fato de que é provável que tenha havido influência da variável escolaridade, porque na época em que essas pessoas eram mais jovens provavelmente os homens tenham tido mais oportunidades para continuar os seus estudos do que as mulheres, pois, atualmente o acesso das mulheres ao ensino superior.aumentou muito.

Nesta pesquisa a precisão foi avaliada pelo teste-reteste e pelo método das metades. Pelo reteste foi obtido um coeficiente de correlação de 0,897, significativa e bastante elevada. Embora Hooper (1983) destaque a importância de realizar investigações da estabilidade temporal para vários intervalos de tempo, ele não apresentou nenhuma pesquisa sobre isso. Não foram 
localizadas pesquisas sobre a precisão pelo reteste, a não ser em Lezak et.al. (2012), que citaram resultados semelhantes, com um intervalo de seis meses e depois reaplicados novamente após 12 meses, em que foi obtido um coeficiente de 0,86, indicando também alta precisão do teste.

Quanto ao método das metades, com a divisão em itens pares e ímpares, na presente pesquisa foi obtido um coeficiente corrigido pela fórmula de Spearman-Brown de 0,884. Hooper (1983) relata, em sua pesquisa com estudantes em 1948, um coeficiente de metades de 0,82. Em 1958, com uma amostra de pacientes psiquiátricos, obteve 0,78 . Citou também os resultados de Gerson, com amostras clínicas, em que foi encontrado um coeficiente de 0,80 . Pode-se observar que esses coeficientes são muito próximos aos deste trabalho e indicam um alto grau de precisão.

Também pode ser lembrado outro índice de precisão relativo à consistência interna encontrado por Lopez, Lazar e Sindy Oh (2003) de 0,882, mas usando o alpha de Cronbach, que confirmam os demais resultados obtidos pelo método das metades. Assim pode-se considerar que a precisão do VOT é satisfatória, tendo sido obtida tanto com amostras clínicas, como não clínicas. Um resultado, apresentado na presente pesquisa e que não foi encontrado nas pesquisas internacionais, se refere ao cálculo das correlações entre os pontos brutos obtidos para cada item do Hooper no teste e no reteste. Todas as correlações foram significantes a 0,01 , ainda que os itens 9 e 10 tenham apresentado correlações menores do que 0,50. Esse é um dado que pode ser melhor analisado em pesquisas futuras.

\section{[Trecho suprimido na versão online]}

Merten (2005) ao estudar a relação do VOT com outros tipos de avaliações de habilidades visoespaciais, distinguiu quatro fatores distintos: a capacidade cognitiva verbal, capacidade cognitiva não-verbal; velocidade de 
processamento de informação e memória verbal. Seus resultados mostraram pontuações maiores para o fator capacidade não verbal no desempenho do VOT.

Também é importante lembrar os resultados da comparação do VOT com alguns subtestes da Escala WISC-III, na pesquisa brasileira de Alves (2007), em que obteve correlação de $+0,373$ com o subteste de Cubos e $-0,510$ com Semelhanças. A correlação com os Cubos foi mais baixa que a obtida nesta pesquisa e a correlação com Semelhanças foi mais alta, mas negativa, o que pode ser explicado por este ser um subteste que investiga a formação de conceitos verbais, mas indica uma falta de relação com a tarefa de nomeação do VOT. A análise de itens mostrou que a ordem dos itens do VOT não está de acordo com a ordem de dificuldade crescente que é esperada, principalmente se um teste tiver critério de interrupção relativo ao número de erros em itens consecutivos. Embora os itens possam ser pontuados em 1, 0,5 ou 0 pontos, 0 que pode dificultar o estabelecimento do seu grau de dificuldade, foi incluída nas tabelas de porcentagens de pontuação de cada item uma coluna que mostra a média de pontos de cada item, que leva em conta as pontuações 1 e 0,5 . Dessa maneira foi possível propor uma nova ordem para apresentação dos itens considerando a sua dificuldade. A Tabela $\mathbf{3 0}$ mostra a nova ordem proposta com as médias de pontos de cada item e a Figura 14 compara a nova ordem dos itens com a original do VOT:

\section{[Trecho suprimido na versão online]}

Greve, et.al. (2000) destacaram as questões de validade de construto do VOT relativas ao papel da capacidade de nomeação das figuras e concluíram que a nomeação, mesmo estando implicada em quase $10 \%$ da variância do teste, teve pouco impacto no desempenho do VOT. Porém, Tosello (2005) com amostra de crianças e adolescentes brasileiros, com idades entre sete a 18 
anos, observou a sensibilidade do teste em relação às diferenças culturais e na atribuição de 1 e 0,5 pontos nos itens que são mais sensíveis às variações do vocabulário, sendo sugerido por essa autora a revisão dos itens 16 (chaleira), 19 (bule) e 25 (cubo). Apesar de Breal (1992); Bräscher (2002); Cegalla (1994) e Ullmann (1977) mostrarem que as questões culturais influenciam na linguagem e o contato entre línguas ou dialetos motivam os seus usuários a fazerem um tipo de classificação por meio de uma expressão vista como sinônima de outra ou, como tendo vários significados, a baixa pontuação encontrada em alguns itens do VOT parecem estar mais relacionada a fatores de estrutura do próprio teste, do que à influência das propriedades polissêmicas na nomeação das figuras.

\section{[Trecho suprimido na versão online]}

O resultado revela que os itens devem ser reordenados em função do nível de dificuldade. Mertem e Beal (1999) apesar de considerarem o teste útil para avaliar a disfunção visoperceptual e visoespacial-organizacional, fazem ressalvas quanto à posição dos itens, pois constataram que não correspondeu à ordem de dificuldade.Também salientaram que, na sua forma atual, os critérios de pontuação de alguns itens parecem ser arbitrários e não fundamentados em pesquisas.

\section{[Trecho suprimido na versão online]}


Portanto, os resultados desta pesquisa consideraram as respostas traduzidas e que foram usadas nas pesquisas brasileiras com o teste, mas é necessária uma nova pesquisa para verificar se as figuras, quando montadas, levariam à mesma dificuldade na nomeação, pois é necessário adequar o critério de 1,0 ou 0,5 ponto ao vocabulário usual para a nossa população e não simplesmente aceitar uma resposta que foi traduzida, visto que o teste pretende medir a percepção da figura e seu reconhecimento e não o vocabulário esperado pelo tradutor.

De qualquer modo, a presente pesquisa fornece normas, bem como dados de precisão e validade satisfatórios que permitem que o Teste Hooper possa ser usado como instrumento auxiliar para o uso nas investigações diagnósticas da capacidade de análise, discriminação visual e síntese visoespacial para a população adulta brasileira.

[Trecho suprimido na versão online] 
[Trecho suprimido na versão online] 
[Trecho suprimido na versão online] 


\section{CONSIDERAÇÕES FINAIS}

Embora este estudo tenha produzido uma base de dados expressivos mostrando a precisão e a validade do VOT para o uso com a população adulta brasileira, são necessárias pesquisas adicionais que investiguem as causas da dificuldade de nomeação em alguns itens, pois na literatura da área diversos autores discutem sobre a possibilidade da influência da nomeação e das questões culturais no teste. Portanto, é relevante verificar se diante da figura montada persistiria a dificuldade da nomeação no desempenho de participantes "normais". Ainda que Azambuja tenha realizado estudo semelhante a essa proposta, sua amostra foi reduzida e a pesquisa pretendia fazer uma comparação entre pacientes com quadro Huntington e controle.

Também deve ser feita uma revisão das respostas consideradas incorretas que ocorrem com maior frequência na população brasileira, analisar a sua relação (semântica, visual, fonológica, cultural, etc.) e, com base nisso, revisar o critério de pontuação de 1,0 ou 0,5 ponto. É importante, ainda, investigar a relação da análise qualitativa das respostas com determinadas patologias.

Estudos sobre o desempenho de crianças e adolescentes no VOT devem ser melhor explorados, visto que poucas pesquisas foram realizadas até o momento no âmbito internacional e, principalmente, no Brasil. Não há dados sólidos na literatura sobre as diferenças entre sexo, idade e escolaridade em crianças e adolescentes, embora Kirk (1992) tenha encontrado diferenças entre sexos em crianças com 12 anos de idade, com maiores pontuações para os meninos. Isto sugere que o desenvolvimento da capacidade de organização visoespacial seja mais lento nas meninas nesta faixa. Além disso, Spreen e Strauss (1998) também destacaram o fator idade, citando que Seidel não encontrou diferenças entre os sexos até os 11 anos de idade. De qualquer modo, o estudo poderia ser estendido até mesmo para as crianças menores de seis anos para investigar o início do desenvolvimento visoespacial e o seu curso ao longo das idades, uma vez que Kirk observou pontuação igual aos adultos para crianças de seis anos. 
Diante do exposto é evidente a importância de estudos que possam contribuir para a padronização do VOT em crianças e adolescentes, uma vez que muitas das dificuldades escolares, principalmente de leitura e escrita, podem estar diretamente relacionadas ou influenciadas pelo déficit no desenvolvimento da organização visoespacial.

Outro aspecto que necessita mais pesquisas brasileiras se refere à capacidade do Teste Hooper de diferenciar pacientes com danos cerebrais ou distúrbios patológicos, pois a normatização realizada neste trabalho somente foi feita com pessoas supostamente normais e é necessário verificar se o desempenho no teste desses pacientes é afetado e qual o possível ponto de corte para esses casos.

Do mesmo modo é necessário verificar se a nova ordem dos itens proposta nesta pesquisa é adequada, pois pode ser que essa mudança possa alterar a dificuldade de alguns itens em função da sua nova posição. As correlações entre teste e reteste foram estatisticamente significantes para todos os itens, com variação entre 0,315 e 0,880. Este resultado indicou que o teste é sensível ao efeito de aprendizagem, não sendo aconselhável a sua reutilização para o mesmo indivíduo.

Dessa forma, espera-se que as tabelas de normas obtidas neste trabalho possam contribuir para o uso do Teste Hooper como instrumento de rastreio na avaliação neuropsicológica. 


\section{REFERÊNCIAS}

Alves, I. C. B. (1998). Variáveis significativas na avaliação da inteligência. Psicologia Escolar e Educacional, 2(2), 109-114.

Alves, L. (2007). Estudos para a adaptação do teste de organização visual de Hooper para a população brasileira e para a validação da versão modificada do teste no Brasil. Monografia de especialização, Universidade FUMEC, Centro de Pós-Graduação da Universidade FUMEC, Belo Horizonte.

Alexander, G. M., Packard, M. G., \& Perterson, B. S. (2002). Sex and spatial position effects on object location memory following intentional learning of object identities. Neurophysics, 40, 1516-1522.

Anastasi, A. (1977). Testes psicológicos. (D. M. Leite, trad., 2 ${ }^{\underline{a}}$ ed.). São Paulo: E.P.U.

Andrade, M. V., Santos, H. F. \& Bueno, A. F. O. (2004). Neuropsicologia hoje. São Paulo: Artes Médicas.

Atkinson, L. R., Atkinson, C. R., Smith, E. E., \& Ben, J. D. (1995). Introdução à Psicologia. (D. Batista, trad., 11ํㅡㄹ ed.). Porto Alegre: Artes Médicas.

Atkinson, J. \& Braddick, O. (1983). Assessment of visual acuity in infancy and early childhood. Acta Ophthalmologyca Supplement, 157(61), 18-26.

Atalaia-Silva, C. K. \& Lourenço, A. R. (2008). Tradução, adaptação e validação de construto do Teste do Relógio aplicado entre idosos no Brasil. Revista de Saúde Pública; 42(5), 930-937.

Azambuja, M. J. (2006). Contribuição ao estudo da linguagem em indivíduos com doença de Huntington. Dissertação de Mestrado. Faculdade de Medicina, Universidade de São Paulo, São Paulo.

Bear, F. M., Connors, W. B. \& Paradiso, A. M. (2002). Neurociências desvendando o sistema nervoso. (J. A. Quillfeldt, trad.; 2 ${ }^{\underline{a}}$ ed.). São Paulo: Editora Artmed.

Bechara, E. (1999). Moderna gramática portuguesa. (37ํㅡㄹ ed.). Rio de Janeiro : Lucerna. 
Bräscher, M. (2002). A ambigüidade na recuperação da informação. Revista de Ciência da Informação,3(1),Acesso em 02 de março de 2015. Disponível em: <http://www.dgz.org.br/fev02/Art_05.htm>.

Bréal, M. (1992). Ensaio de Semântica: Ciência das significações. (Férras et al., trad.). São Paulo: Educ \& Pontes,

Biederman, I. (1987). Recognition by components: A theory of human image understanding. Psychological Review, 94(2), 115-147.

Boyd, J. L. (1981). A validity study of the Hooper Visual Organization Test. Journal of Consulting and Clinical Psychology, 49(1), 15-19.

Bräscher, M. (2002). A ambigüidade na recuperação da informação. Revista de Ciência da Informação, 3(1). Acesso em 02 de março de 2015. Disponível em: <http://www.dgz.org.br/fev02/Art_05.htm>.

Bréal, M. (1992). Ensaio de Semântica: Ciência das significações. (A.Férras et al., trad.). São Paulo: Educ \& Pontes.

Cagnin, S. (2010). A pesquisa em Neuropsicologia: Desenvolvimento histórico, questões teóricas e metodológicas. Psicologia em Pesquisa, 4 (2), 118-134.

Caixeta, L. (2010). Demências do tipo não Alzheimer. Porto Alegre: Editora Artmed.

Capovilla, A. G. S. (2005). Neuropsicologia cognitiva e avaliação neuropsicológica. In E. Coutinho \& F. C. Capovilla (Orgs.). Temas em Neuropsicolinguística. Ribeirão Preto: Tecmedd.

Carter, R., Aldridge, S., Page, M. \& Parker, S. (2009a). Neuropsicologia cognitiva e Psicologia cognitiva: O que o estudo da cognição deficitária pode nos dizer sobre o funcionamento cognitivo normal? Psicologia em Pesquisa, 3(1), 16-30. Acesso em 12 de abril de 2015, http://pepsic.bvsalud.org/scielo.php?script=sci_arttext\&pid=S1982$12472009000100003 \&$ lng=pt\&tlng=pt. .

Carter, R., Aldridge, S., Page, M. \& Parker, S. (2009b). O livro do cérebro (F. Jones, trad.). São Paulo: Editora Duetto.

Cattell, J. McK. (1890). Mental tests and measurements. Mind, 15, 373-380. 
Cegalla, D, P. (1994). Novíssima gramática da língua portuguesa. São Paulo: Nacional.

Costa, M. F. (2010).

Costa, M. F. (2010). Psicofísica Clínica: Ciência básica e sua aplicação na saúde. Revista Psicologia e Saúde, 2(1), 50-55.

Costa, M. F., Oliveira, A. G. F., Bergamasco, N. H. P. \& Ventura, D. F. (2006). Medidas psicofísicas e eletrofisiológicas da função visual do recém-nascido: Uma revisão. Psicologia USP, 17(4), 15-33.

Conselho Federal de Oftalmologia (2010). Cegueira Cortical e Deficiência Visual. Disponível em: http://www.deficienciavisual.pt/sdcegueira_cortical.htm. Recuperado em: 06.02. 2015.

Conselho Federal de Psicologia (2003). Resolução CPF no 002/2003, de 24 de março de 2003. Define e regulamenta o uso, a elaboração e a comercialização de testes psicológicos e revoga a ResoluçãoCPF $n^{\circ}$ 025/2001. Acesso em: 27/07/ 2009. Disponível em: <http://www.pol.org.br/legislacao/doc/resolucao2003_2.doc>.

Damásio, A. (2000). O mistério da consciência. (L. T. Motta, trad.). São Paulo: Editora Companhia das Letras.

D'Espósito, M. (2000). Functional neuroimaging of cognition.Seminars in Neurology, 20(4), 487-498.

Dudel, J. (1980).Fisiologia geral dos órgãos dos sentidos: Psicofísica. In F. R. Schmidt, (Org.). Fisiologia sensorial. (pp.1-5; H. T. Bucku, trad., 3ª̂ed.) São Paulo: Editora Pedagógica de São Paulo.

Duncan, S. J. (1997). Imaging and epilepsy. Brain,120, 339-77.

Eisenman, R., \& Coyle, J. R. A. F. (1965). Absence of false positives on the Hooper Visual Organization Test. Psychological Reports.17, 417-418.

Ellis, W. A. \& Young, W. A. (1996). Human cognitive Neuropsychology: A textbook with readings. $\left(2^{\frac{\text { nd }}{}}\right.$ ed). Hove: Psychology Press.

Engelmann, A. (2002). A Psicologia da gestalt e a ciência empírica contemporânea. Psicologia Teoria e Pesquisa, 18(1), pp. 1-16 
Ekman-Lundy, L. (2008). Neurociências: Fundamentos para a reabilitação (F. D. Mundim \& V. R. S. Varga., trad.; $3^{\text {rd }}$ ed.), Rio de Janeiro. Elsevier.

Fielder, R. A. \& Moseley, J. M. (1988). Do we need to measure the vision of children? Journal of the Royal Society of Medicine, 81(7), 380-383.

Ferreira, E. E. S. (2006).Alterações ocupacionais e sociais em pacientes com esquizofrenia: Relação com perfis metabólicos nos circuitos fronto-tálamoestriatais à ressonância magnética espectroscópica. Dissertação de mestrado não-publicada. Programa de Pós-Graduação em Clínica Médica e Ciências da Saúde: Neurociências, Pontifícia Universidade Católica do Rio Grande do Sul,. Porto Alegre.

Fiori, N. (2008). As neurociências cognitivas. (S. M. S. Fuhrmann, trad.). Rio de Janeiro: Vozes.

Fonseca, P. R., Pureza, J., Gonçalves, H., Oliveira, G. R., Kristensen, H. C., \& Stein, M. L. (2011). Estudos sobre cognição humana na revista Psico nos últimos 40 anos. Psico, 42 (3), 295-302.

Forgus, R. H. (1971). Percepção: O processo básico do desenvolvimento cognitivo. (N. P. Mejias, trad.). São Paulo: Editora Herder.

Freitas, K, N. (2006). Desenvolvimento humano, organização funcional do cérebro e aprendizagem no pensamento de Luria e de Vygotsky. Ciência \& Cognição, 9, 91-96. <http://www.cienciasecognicao.org> Acesso em: março/2015.

Fluentes, D., Andrade, C. P. S., Diniz, M. F. L., Baise, M., Camargo, P. H. C. (2012). Avaliação neuropsicológica. In V. O. Forlenza \& C. E. Miguel (Ed.). Compêndio de clínica psiquiátrica. Barueri: Editora Manole.

Gagliardo, G. R. G. H. (2006). Desenvolvimento da coordenação visomotora. In M. L. V. M \& Ribeiro, G. M. V. Gonçalves (Org). Neurologia do desenvolvimento da criança. Rio de Janeiro: Livraria e Editora Revinter Ltda.

Galton, F. (1879). Psychometric experiments. Brain. 2, 149-162.

Gazzaniga, S. M. (2005). Ciência psicológica: Mente, cérebro e comportamento. Porto Alegre: Artmed. 
Gazzaniga, S. M.; Ivry, B. R. \& Mangun, R. G. (2006). Neurociência cognitiva (R. M. Rosat; D. Zancan; C. B. O. Netto; A. R. Consiglio, trads.; $2^{\underline{a}}$ ed.). Porto Alegre: Artmed.

Giannakou, M. \& Kosmidis, M. H. (2006). Cultural appropriateness of the Hooper Visual Organization Test? Greek normative data. Journal of Clinical and Experimental Neuropsychology. 28(6), 1023-1029.

Gil, R. (2002). Neuropsicologia. (2- ed.; M. A. A. S. Dória, trad.), São Paulo: Editora Santos Ltda.

Guilford, J.P. \& Fruchter, B. (1978). Fundamental Statistics in Psychology and Education (6th ed.). New York: McGraw Hill.

Guilford, J. P. (1950).Fundamental statistics in Psychology and education (2th ed.). New York: McGraw-Hill.

Goodwin, C. J. (2005). História da Psicologia moderna. (M. Rosas, trad.). São Paulo: Cultrix.

Gregory, R. L. (1979). Olho e cérebro: Psicologia da visão. (A. Cabral, trad). Rio de Janeiro: Zahar.

Greve, K. W., Lindberg, R. F., Bianchini, K, J., \& Adams, D. (2000). Construct validity and predictive value of the Hooper Visual Organization Test in stroke rehabilitation. Applied Neuropsychology, 7(4), 215-222.

Guyton, C. A., \& Hall, E. J. (2012). Fundamentos de Fisiologia. (12ª ed.; A. Soares \& S. Spada, trads.). Rio de Janeiro: Editora Elsevier Ltda.

Higgins, S. E., \& George, S. M. (2010). Neurociências para Psiquiatria clínica.A fisiopatologia do comportamento e da doença mental. (R. Pizzato \& C. Monteiro, trads.). Porto Alegre: Artmed.

Hirose, G., Kin, T., \& Murakami, E. (1977). Alexia without agrafia associated with right occipital lesion. Journal of Neurology, Neurosurgery, and Psychiatry, 40(3), 225-227.

Hooper, H. E. (1983). The Hooper Visual Organization Test (VOT). Beverly Hills: Western Psychological Services. 
Ilari, R. (2009). A noção semântica de ambigüidade. Veredas: Revista de Estudos Linguísticos, 1(1), 51-71. Acesso em: 11/03/2015. Disponível em: http://www.ufj.br/revistaveredas/files/2009/12/artigo047.pdf.

Jefferson, L. A., Wong, S., Bolen, E., Ozonoff, A., Green, C. R., \& Stern, A, R. (2006). Cognitive correlates of VOT performance differ between individuals with mild cognitive impairment and normal controls. Archives of Clinical Neuropsychology, 21(5), 405-412.

Joseph, R. (1988). Dual mental functioning in a split-brain patient. Journal of Clinical Psychology, 44(5), 770-779.

Kandel, R. E., Schwartz, H. J., \& Jessel, M. T. (2000). Fundamentos da Neurociência e do comportamento (C. A. Esbérard \& M. C. Engelhardt, trad.). Rio de Janeiro: Guanabara Koogan.

Kirk, U. (1992). Evidence for early acquisition of visual organization ability: A developmental study. Clinical Neuropsychologist, 6(2), 171-177.

Krech, D. \& Crutchfield,R. (1980). Elementos de Psicologia (D. M. Leite \& M. L. M. Leite, trad.; vol. 2, 6 a $^{\underline{a}}$ ed.). São Paulo: Livraria Pioneira Editora.

Kristensen, H. C., Almeida, M. M. R; \& Gomes, W. (2001). Desenvolvimento histórico e fundamentos metodológicos da Neuropsicologia Cognitiva. Psicologia Reflexão e Crítica, 14(2), 259-274.

Koeppen, M. B., \& Stanton, A. B. (2009). Berne \& Levy Fisiologia. (6ª ed.). Rio de Janeiro: Editora Elsevier Ltda.

Koffka, K. (1983). Princípios de Psicologia da gestalt. (A. Cabral, trad.). São Paulo: Editora Cultrix.

Köhler, W. (1968). Psicologia da gestalt. (D. Jardim, trad.). Belo Horizonte: Ed. Itatiaia Ltda.

Kumano, H. \& Uka, T. (2013). Neuronal mechanisms of visual perceptual learning. BehaviouralBrain Research, 249,75-80.

Lacks, P. (2000). Visuoconstructive abilities. In G. Marnat-Groth (Ed.), Neuropsychological assessment in clinical practice: A guide to test interpretation and integration. New York: John Wiley \& Sons, Inc. 
Lefèvre, A. B. (1989). Neuropsicologia Infantil. São Paulo: Sarvier.

Lefèvre, B.H. (1998). A avaliação neuropsicológica do adulto. In: C. F. Capovilla, J. M., Gonçalves \& E. C. Macedo (Orgs). Tecnologia em (re) habilitação cognitiva. São Paulo: Edunisc.

Lent, R. (2005). Cem bilhões de neurônios: Conceitos fundamentais de neurociência. São Paulo: Editora Atheneu.

Lezak, M. D. (1995). Neuropsychological assessment. (3 ${ }^{\mathrm{a}}$ ed.). New York: Oxford University Press.

Lezak, M. D., Howieson, B. D., Bigler, D. E., \& Tranel, D. (2012). Neuropsychological Assessment. (5 $5^{\text {th }}$ ed.). New York: Oxford University Press.

Libon, J. D., Glosser, G., Malamut, L. B., Kaplan, E., Goldberg, E., Swenson, R., \& Sands, P. L. (1994). Age, executive functions, and visuospatial functioning in healthy older adults. Neuropsychology, 8(1), 38-43.

Lima, M. G., Gomes, D. B., Ventura, D. F. \& Silveira, L. C. L. (2011). Métodos utilizados na avaliação psicofísica da visão de cores humana. Psicologia USP, 22 (1), 197-222.

Lopes, E. (2007). Fundamentos da Linguística contemporânea. (23르ed.). São Paulo: Editora Pensamento-Cultrix Ltda,

Lopez, N. M., Lazar, D. M., \& Oh, S. (2003). Psychometric properties of the Hooper Visual Organization Test. Assessment 10(1), 66-70.

Lopez, N, M; Lazar, D, M; Império, M, S. (2005). A qualitative analysis of inaccurate responses on the Hooper Visual Organization Test. Perceptual and Motor Skills, 100(3 Pt 1),695-702.

Mäder, M. J. (1996). Avaliação neuropsicológica: Aspectos históricos e situação atual. Psicologia: Ciência e Profissão, 16(3), 12-18.

Maia, J. D. (1995). Gramática: Teoria e exercícios. São Paulo: Ática.

Malloy-Diniz, F. L., Fluentes, D., Mattos, P., Abreu, N. et al. (2010). Avaliação neuropsicológica. Porto Alegre: Artmed. 
Mansur, L. L., Carthery, T. M., Carameli, P., \& Nitrini, R. (2005). Linguagem e cognição da doença de Alzheimer. Psicologia: Reflexão e Crítica, 18(3), 300-307.

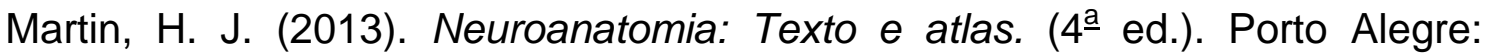
AMGH Editora Ltda.

Mas Soriano, C., Blanck. G. G., Ripoll, R. A. D., García, T. M., \& Martínez, V. A. (2007). Fundamentos de neurociência. Catalunya: Editorial UOC.

Mattei, T. A., \& Mattei, J. A. (2005). A cognição espacial e seus distúrbios: O papel do córtex parietal posterior. Neurociências,,13(2), 93-99.

Mendoza, E. J., \& Foundas, L. A. (2008). A neurobehavioral approach. New York: Springer Science Business Media, Inc.

Merten, T. (2005). Factor structure of the Hooper Visual Organization Test: A Cross-cultural replication and extension. Archives of Clinical Neuropsychology, 20(1), 123-128.

Merten, T., \& Beal, C. (1999). An analysis of the Hooper Visual Organization Test with neurological patients. The Clinical Neuropsychologist, 13(4), 521529.

Mesulam, Marsel-M. (2000). Principles of behavioral and cognitive Neurology. $\left(2^{\text {nd }}\right.$ ed). New York: Oxford University Press, Inc.

Meyer, E. (1989). Simultaneous correction for tracer arrival delay and dispersion in CBF measurements by the $\mathrm{H} 215 \mathrm{O}$ autoradiographic method and dynamic PET. Journal of Nuclear Medicine; 30,1069-1078.

Milner, A. D. \& Goodale, M. A. (1995). The visual brain in action. New York: Oxford University Press.

Miotto, C. E. (2007). Neuropsicologia: Conceitos fundamentais. In C. E. Miotto, S. C. M. Lucia \& M. Scaff (Orgs). Neuropsicologia e as Interfaces com as Neurociências. (pp. 137-142). São Paulo: Casa do Psicólogo.

Monteiro, R. L, M., \& Roizenblatt, J. (2010). O exame neuroftalmológico da criança. In A. Diament, S. Cypel, \& C. U. Reed, (Eds.). Neurologia Infantil. (5aㅡ ed.).São Paulo: Editora Atheneu. 
Nadler, J. D., Grace J., White, D. A., Butters, M. A., \& Mallory, P. F. (1996). Laterality differences in quantitative and qualitative Hooper performance. Archives of Clinical Neuropsychology, 11(3), 223-229.

Ohlweiler, L., \& Guardiola, A. (2006). Disgnosias. In T. N Rotta, L. Ohlweiler, \& S. R. Riesgo (Org.). Transtornos da aprendizagem: Abordagem neurobiológica e multidisciplinar. Porto Alegre: Artmed.

Oliveira, A. G. F. (2007). Desenvolvimento das funções de acuidade visual e sensibilidade ao contraste visual medidas por potenciais visuais provocados de varredura em crianças nascidas a termo e prematuras. Tese de Doutorado. Instituto de Psicologia, Universidade de São Paulo, São Paulo.

Oliveira, A. G. F., Costa, M. F., \& Ventura, D. F. (2007). Desenvolvimento da visão de contrastes em bebês. In: Fernandez, J. L., \& Sllva, M. T. A. (Org.). Intersecções entre Psicologia e Neurociências.Rio de Janeiro: Editora MedBook.

Oliveira, P. A., Scivoletto' S. \& Cunha, P. J. (2010). Estudos neuropsicológicos e de neuroimagem associados ao estresse emocional na infância e adolescência. Archives of Clinical Psychiatry, 37(6), 271-279.

Ortiz, K. Z. (2010). Distúrbios neurológicos adquiridos. (2ª ed.). São Paulo: Ed. Manole, .

Parente, P. M. A. M; Senaha, H. L. M. (2010). Dislexias Adquiridas. In: Z. K. Ortiz, (Org.). Distúrbios Neurológicos adquiridos. (2 $\underline{a}$ ed.) Barueri: Editora Manole.

Paul, R; Cohen, R; Moser, D; Ott, B; Zawacki, T; Gordon, N. (2001). Performance on the Hooper Visual Organization Test in patients diagnosed with subcortical vascular dementia: Relation to naming performance. 14(2), 93-97.

Pereira, R. J., Reis, M. A., \& Magalhães, Z. (2003). Neuroanatomia funcional: Anatomia das áreas activáveis nos usuais paradigmas em ressonância magnética funcional. Acta Médica Portuguesa, 16,107-116. 
Petersen, S. E., \& Fiez, J. A. (1993). The processing of single words studied whit positron emission tomography. Annual Review of Neuroscience; 16, 509-30.

PsycNET. (2001). Clinical Neuropsychology now recognized as specialty. $\begin{array}{lllll}\text { Acesso em } & 20 & \text { l032015. Disponível em: }\end{array}$ http://www.apa.org/releases/crsppp.htm

Rao, S. M. (1996). Neuropshychological assessment. In B. S. Fogel \& R.B. Schiffer (Eds.). Neuropsychiatry. Baltimore: Williams \& Wilkins.

Rey, A. (1999). Figuras Complexas de Rey. (T. Cabral, trad.). São Paulo: Ed. Casa do Psicólogo.

Ricker, J. H., \& Axelrod, B. N. (1995). Hooper Visual Organization Test: Effects of object naming ability. Clinical Neuropsychologist, 9(1), 57-62.

Riddoch, M. J. \& Humprereys, G. W. (2001). Object recognition. In B. Repp (Ed.) The handbook of Cognitive Neuropsychology: What deficits reveal about the human mind. (pp. 45-74). Philadelphia: Psychology Press.

Rocha, C. C. (2012). A formação do português brasileiro pela observação de expressões idiomáticas. Revista ContraPonto, 2, (2), 14-27.

Rodrigues, V. F. (2010). Fisiologia sensorial. Revista da Biologia, 5, 23-32.

Sacks, O. (1997). O homem que confundiu sua mulher com um chapéu (L. T. Motta, trad.). São Paulo: Companhia das Letras.

Sacks, O. (2010). O olhar da mente. (L. T. Motta, trad.). São Paulo:Companhia das Letras.

Saconni, A. L. (1995). Nossa gramática: Teoria e prática. São Paulo: Atual.

Santana, P. A. (2002). Escrita e afasia. Campinas: Plexus Editora.

Santos, H. F. (2005). Reabilitação neuropsicológica pediátrica. Psicologia Ciência e Profissão, 25(3), 450-461.

Sbordone, J. R., Saul, E. R., Purisch, D., \& Arnold. (2007). Neuropsychology for psychologists, health care professionals and attorneys. ( $3^{\text {rd }}$ ed.). New York: CRC Press Taylor \& Francis Group. 
Silva, B. E. (2012). Polissemia e homonímia: Proximidade e distanciamento em lexemas do espanhol e do português. Revista Prólingua, 7(2), 5-24.

Silva, B, L. (2006). Ambigüidades da língua portuguesa: Recorte classificatório para a elaboração de um modelo ontológico. Dissertação de Mestrado. Universidade de Brasília, Brasília.

Silva, D. (2014). De onde vêm as palavras. (17를 ed.). Rio de Janeiro: Lexikon.

Spinillo, G. A. \& Roazzi, A. (1989). A atuação do psicólogo na área cognitiva: reflexões e questionamentos.Psicologia: Ciência e Profissão, 9(3), 20-25.

Spreen, O. \& Strauss, E. (1998). A compendium of neuropsycological test. ( $2^{\text {nd }}$ ed.). New York: Oxford University Press, Inc.

Springer, S. P. \& Deutsch, G. (1998). Cérebro esquerdo, cérebro direito (T. Yoshiura, trad.; $2^{\underline{a}}$ ed.). São Paulo: Summus Editorial Ltda.

Springer, S. P. \& Deutsch, G. (2008).Cérebro esquerdo, cérebro direito. Perspectivas da neurociência cognitiva (H. T. Buckup, trad., $5^{\underline{a}}$ ed.). São Paulo: Santos Editora.

Squire, R. L., Berg, D., Bloom, E. F., Lac, D. S., Ghosh, A., \& Spitzer, C. N. (2008). Fundamental neurocience. ( $3^{\text {rd }}$ ed.). Oxford, UK. Elsevier Inc.

Statt, A. D. (1978). Introdução à Psicologia. (A. L. Neri, trad.). São Paulo: Harper \& Row do Brasil Ltda.

Sternberg, R. J. (2010). Psicologia Cognitiva. (A. M. D. Luche \& R. Galman, trads., J. M. Nunes, rev. Técnica, $5^{\mathrm{a}}$ ed.). São Paulo: Cengage Learning.

Tamkin, A. S. \& Jacobsen, R. (1984). Age-related norms for the Hooper Visual Organization Test, Journal of Clinical Psychology, 40(6), 1459-1463.

Tamkin, A. S., \& Kunce, J. T. (1985). A comparison of three neuropsychological tests: the Weigl, Hooper, and Benton. Journal of Clinical Psychology, 41(5), 660-664.

Thiers, V. O.; Argimon, I. I. L. \& Nascimento, R. L. (2005). Neuropsicologia: A expressão comportamental dos processos mentais. Psicologia. pt - O Portal dos Psicólogos. Disponível em: http://www. psicologia.com.pt/artigos, v.48, p. 1-10. > acesso em 28.01.2015. 
Tosello, T. J. D. (2005). Contribuição para o estudo normativo do Hooper Visual Organization Test. Psicologia Hospitalar. 3(1),.59-83.

Urbina, S. (2007). Fundamentos da testagem psicológica. (C. Dornelles, trad.). Porto Alegre: Artméd.

Ullmann, S. (1977). Semântica: Uma introdução à ciência do significado. (4a ed.). Lisboa: Fundação Calouste Gulbenkian.

Vasconcellos, C. L. J. \& Oliveira, V. R. (2004). História da Psicologia cognitiva: Antecedentes da Psicologia Cognitiva. Revista de Saúde Mental em Foco do CESUCA, 1(1). Acesso março 2015. Disponível em: http://ojs.cesuca.edu.br/index.php/saudementalemfoco/artigo/

Vigotski, L. S. (2001). A construção do pensamento e da linguagem. (P. Bezerra, trad.). São Paulo: Ed. Martins Fontes.

Wang, P. L. (1977) Visual organization ability in brain-damaged adults. Perceptual and Motor Skills, 45, 723-728.

Wertheimer, M. (1991). Pequena história da Psicologia (L. L. Oliveira, trad.: $9^{a}$ ed.). São Paulo: Nacional.

Wechsler, D. (1997). Manual para administração e avaliação. (Adaptação e padronização de uma amostra brasileiraE. Nascimento). (M. C. V. M. Silva, trad.). São Paulo: Casa do Psicólogo.

Wurtz, H. R., Komatsu, H., Yamasaki, G. S. D., \& Dürsteler, R. M. (1990). Cortical visual motion processing for oculomotor Control. New York: Ed. Raven Press.

Zavaglia, C. (2003). Ambiguidade gerada pela homonímia: Revisitação teórica, linhas limítrofes com a polissemia e proposta de critérios distintivos. DELTA, 19 (2), 237-266. Acesso em 2/03/2015. Disponível: em:<http://www.scielo.br/scielo.php?script=sci_arttext\&pid=S0102$44502003000200001 \& \operatorname{lng}=e n \& n r m=i s o>$.

Zihl, J. (1989). Cerebral disturbances of elementary visual functions. In W. J. Brown \& L.Erlbaum (Ed.). Neuropsychology of visual perception. New York: Associates publishers Hillsdale, The IRBN Press. 


\section{APÊNDICE A - Critérios para a participação no Teste Hooper Organização Visual}

Por favor, leia atentamente a cada questão e responda de forma clara e concisa.

NOME:

IDADE:

PROFISSÂO:

ESCOLARIDADE:

DATA:

1. POSSUI BOM DOMÍNIO DA LÍNGUA PORTUGUESA?

R.

2. POSSUI DIFICULDADE DE COMPREENSÃO OU EXPRESSÃO?

R.:

3. POSSUI ALGUMA DIFICULDADE EM NOMEAR COISAS?

R.

4. POSSUI BOA ACUIDADE VISUAL?

R.

5. FAZ USO DE LENTES CORRETIVAS?

R.

6. POSSUI ALGUM TIPO DE DOENÇA NEUROLÓGICA OU PSIQUIÁTRICA QUE JÁ TENHA SIDO DIAGNOTICADA?

R.

7. FAZ USO DE ALGUM TIPO DE DROGA LÍCITA OU ILÍCITA?

R.: 


\section{APÊNDICE B- Termo de consentimento livre e esclarecido}

Estamos realizando uma pesquisa para construir tabelas normativas para a utilização no Brasil do Teste Hooper Organização Visual. Este teste é usado para auxiliar no diagnóstico de adolescentes e adultos para organizar estímulos visuais, trata-se de um teste que é particularmente sensível para avaliar pacientes com prejuízos neurológicos. A tarefa é identificar visualmente e nomear qual figura seria formada, se as partes do desenho fossem juntadas corretamente.

A aplicação deste instrumento não causa desconforto e/ou risco e somente será realizada se houver sua concordância. Porém, caso seja necessário, será oferecida pela pesquisadora, toda a assistência necessária ao seu bem-estar, sem que haja qualquer ônus para você. Não há benefício direto para você, mas os resultados do estudo poderão auxiliar no futuro o trabalho dos psicólogos no diagnóstico de outras pessoas com dificuldades visuoespaciais e doenças neurológicas.

A sua colaboração é muito importante, porém, NÃO É OBRIGATÓRIA. Caso não queira participar, sinta-se à vontade para recusar ou devolver esta folha em branco. As informações obtidas serão analisadas em conjunto com a de outras pessoas, não sendo divulgada a identificação de nenhum participante da pesquisa.

Não há despesas pessoais para o participante, nem compensação financeira relacionada à sua participação. A pesquisadora se compromete a utilizar os dados e o material coletado somente para esta pesquisa, cujos resultados grupais poderão ser publicados ou apresentados em Congressos Científicos. A coordenação desta pesquisa é da responsabilidade da pesquisadora e Psicóloga Roseli Almeida da Costa Ameni do Instituto de Psicologia da Universidade de São Paulo (IPUSP), sob a orientação da Profa.Dra. Irai Cristina Boccato Alves do Instituto de Psicologia da Universidade de São Paulo (IPUSP). Dúvidas relativas as questões éticas entrar em contato com o Comitê de Ética em Pesquisa com Seres Humanos do IPUSP : Instituto de Psicologia da Universidade de São Paulo: Av. Professor Mello Moraes, 
1721 - Bloco G, $2^{\circ}$ andar, sala 27 CEP 05508-030 - Cidade Universitária - São Paulo/SP E-mail: ceph.ip@usp.br - Telefone: (11) 3091-4182

Contato com a pesquisadora: E-mail: roseamenipsico@gmail.com - End. Institucional: Laboratório interdepartamental de Técnicas de Exame Psicológico - Av. Prof. Mello Moraes, 1721 - Cidade Universitária - São Paulo. Fone: (11) 3091-4190

Se estiver de acordo em participar da pesquisa, solicito colocar o seu nome e assinar abaixo nas duas vias.

Concordo em participar tendo a ciência de que poderei desistir a qualquer momento, caso seja da minha vontade.

Nome

e

assinatura

do

Participante:

Nome

e

assinatura

da

Pesquisadora:

Data: 
APÊNDICE C-Instrução literal de aplicação do VOT conforme o manual original (Hooper, 1983, p.4).

[Trecho suprimido na versão online] 